\title{
Modelling and mapping of state disparities associated with female genital mutilation/cutting prevalence among girls aged 0-14 years in Nigeria: Evidence from DHS and MICS 2003-2017
}

Ngianga-Bakwin Kandala

Paul Komba

Chibuzor Christopher Nnanatu

Glory Atilola

Lubanzadio Mavatikua

See next page for additional authors

Follow this and additional works at: https://knowledgecommons.popcouncil.org/departments_sbsr-rh

Part of the Demography, Population, and Ecology Commons, Family, Life Course, and Society Commons, Gender and Sexuality Commons, International Public Health Commons, and the Medicine and Health Commons How does access to this work benefit you? Let us know!

\section{Recommended Citation}

Kandala, Ngianga-Bakwin, Paul Komba, Chibuzor Christopher Nnanatu, Glory Atilola, Lubanzadio Mavatikua, Zhuzhi Moore, and Dennis Matanda. 2020. "Modelling and mapping of state disparities associated with female genital mutilation/cutting prevalence among girls aged 0-14 years in Nigeria: Evidence from DHS and MICS 2003-2017," Evidence to End FGM/C: Research to Help Girls and Women Thrive. New York: Population Council. 


\section{Authors}

Ngianga-Bakwin Kandala, Paul Komba, Chibuzor Christopher Nnanatu, Glory Atilola, Lubanzadio Mavatikua, Zhuzhi Moore, and Dennis Matanda 


\section{Evidence to End FGM/C}

Research to Help Girls and Women Thrive

\section{MODELLING AND MAPPING OF RISK FACTORS OF FGM/C PREVALENCE AMONG GIRLS AGED 0-14 IN NIGERIA:}

EVIDENCE FROM DHS AND MICS 2003-2017

January 2020 


\section{MODELLING AND MAPPING OF RISK FACTORS OF FGM/C PREVALENCE AMONG GIRLS AGED 0-14 YEARS IN NIGERIA:}

Evidence from DHS and MICS 2003-2017

NGIANGA-BAKWIN KANDALA PAUL KOMBA CHIBUZOR CHRISTOPHER NNANATU GLORY ATILOLA LUBANZADIO MAVATIKUA UNIVERSITY OF NORTHUMBRIA AT NEWCASTLE, UK

ZHUZHI MOORE INDEPENDENT CONSULTANT, USA

DENNIS MATANDA POPULATION COUNCIL, NAIROBI 
Evidence to End FGM/C: Research to Help Girls and Women Thrive generates evidence to inform and influence investments, policies, and programmes for ending female genital mutilation/cutting in different contexts. Evidence to End FGM/C is led by the Population Council, Nairobi in partnership with the Africa Coordinating Centre for the Abandonment of Female Genital Mutilation/Cutting (ACCAF), Kenya; the Global Research and Advocacy Group (GRAG), Senegal; Population Council, Nigeria; Population Council, Egypt; Population Council, Ethiopia; MannionDaniels, Ltd. (MD); Population Reference Bureau (PRB); University of California, San Diego (Dr. Gerry Mackie); and University of Washington, Seattle (Prof. Bettina Shell-Duncan).

POPULATION COUNCIL

Ideas. Evidence. Impact.
The Population Council confronts critical health and development issues-from stopping the spread of HIV to improving reproductive health and ensuring that young people lead full and productive lives. Through biomedical, social science, and public health research in 50 countries, we work with our partners to deliver solutions that lead to more effective policies, programmes, and technologies that improve lives around the world. Established in 1952 and headquartered in New York, the Council is a nongovernmental, nonprofit organisation governed by an international board of trustees. www.popcouncil.org

Suggested Citation: Kandala, Ngianga-Bakwin, Paul Komba, Chibuzor Christopher Nnanatu, Glory Atilola, Lubanzadio Mavatikua, Zhuzhi Moore, and Dennis Matanda. 2020. "Modelling and Mapping of State Disparities Associated with Female Genital Mutilation/Cutting Prevalence Among Girls Aged 0-14 Years in Nigeria: Evidence from DHS and MICS 2003-2017." Evidence to End FGM/C: Research to Help Girls and Women Thrive. New York: Population Council.

\section{(c) 2020. The Population Council, Inc.}

This is a working paper and represents research in progress. This paper represents the opinions of the authors and is the product of professional research. This paper has not been peer reviewed, and this version may be updated with additional analyses in subsequent publications. Contact: Ngianga-Bakwin Kandala, ngianga-bakwin.kandala@northumbria.ac.uk.

Please address any inquiries about the Evidence to End FGM/C programme consortium to: Dr Jacinta Muteshi, Project Director, imuteshi@popcouncil.org

Funded by:

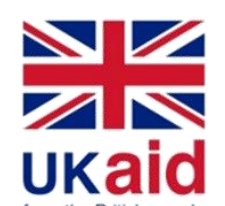

This document is an output from a programme funded by the UK Aid from the UK government for the benefit of developing countries. However, the views expressed and information contained in it are not necessarily those of, or endorsed by the UK government, which can accept no responsibility for such views or information or for any reliance placed on them. 


\section{Table of Contents}

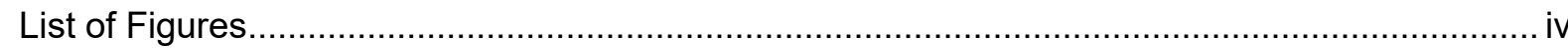

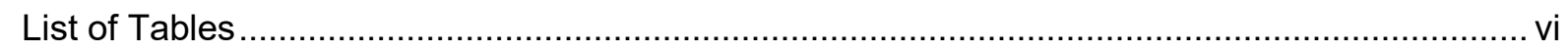

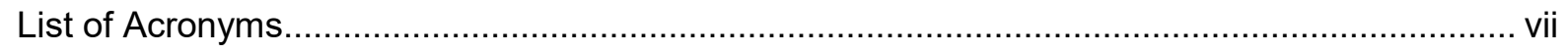

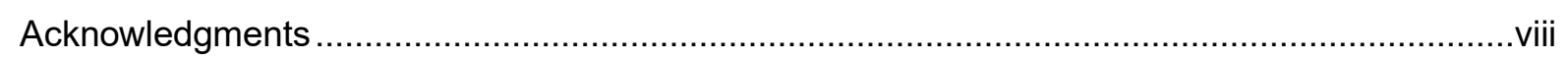

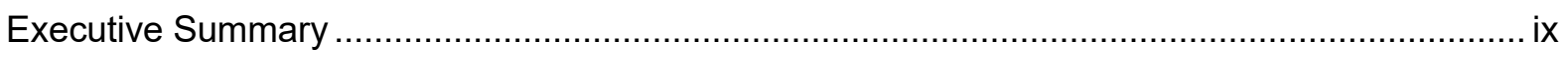

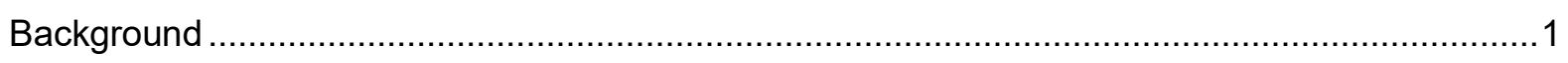

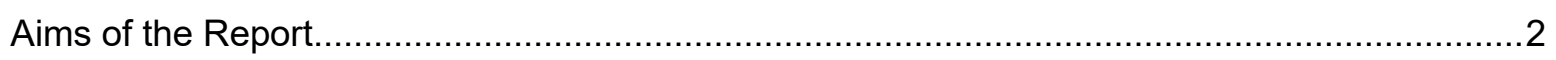

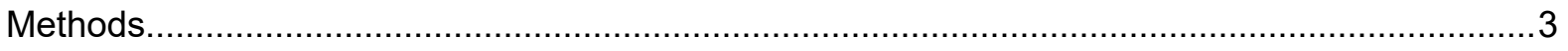

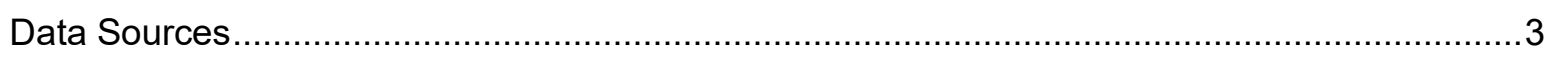

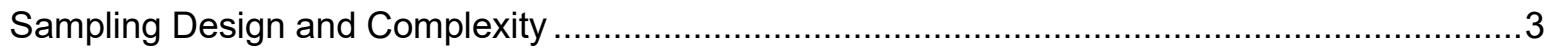

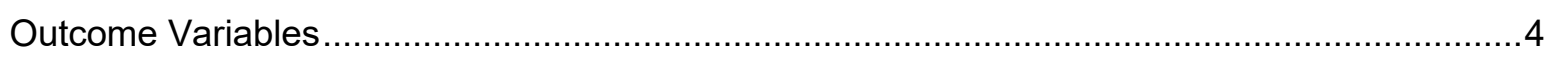

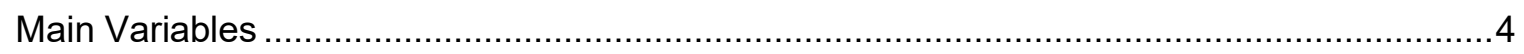

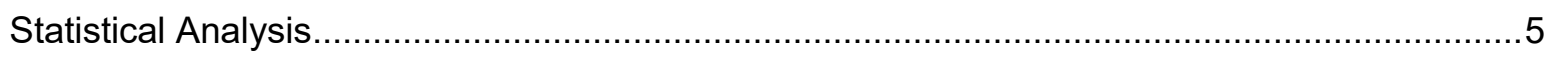

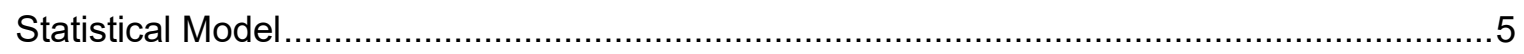

Multivariate Bayesian Geo-additive Approach ............................................................ 6

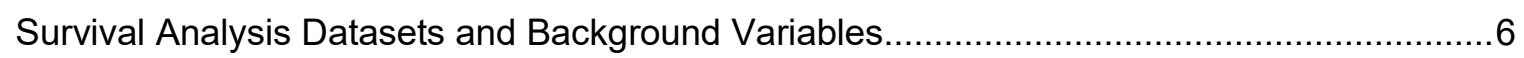

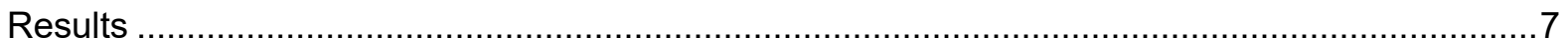

Key Results from Bayesian Geo-additive Analyses .........................................................

Bayesian Hierarchical Geo-additive Logistic Regression Models .........................................

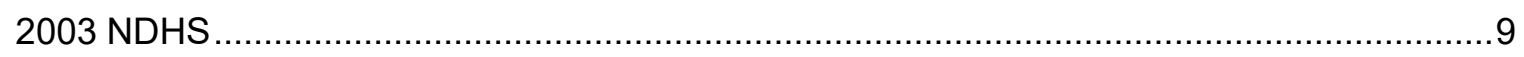

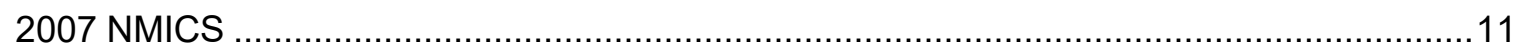

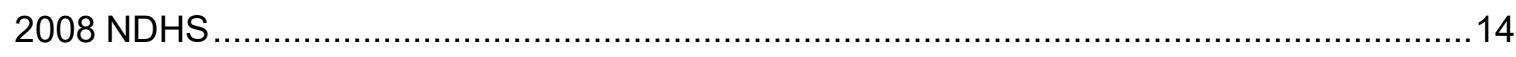

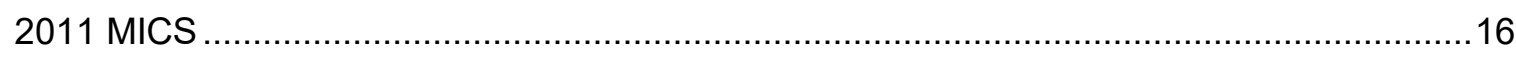

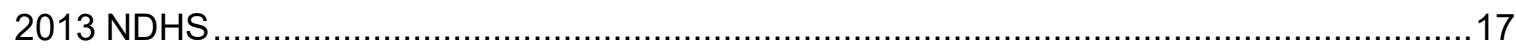

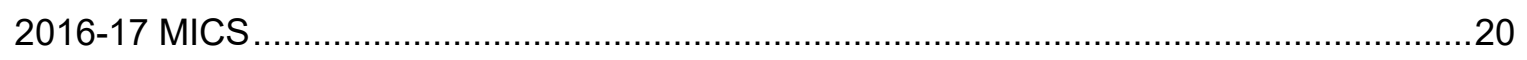

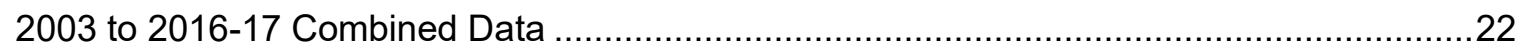

Age at Cutting: Findings of Descriptive Survival Analysis of Girls' FGM/C Status in 2013 .......23

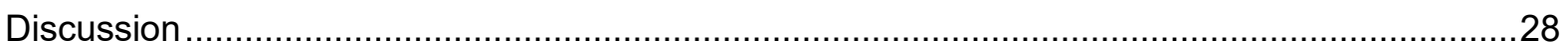

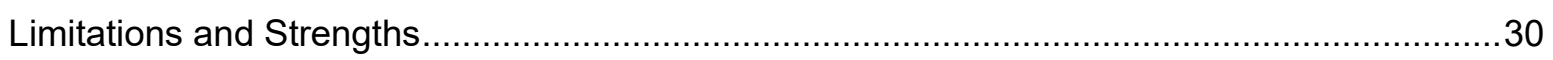

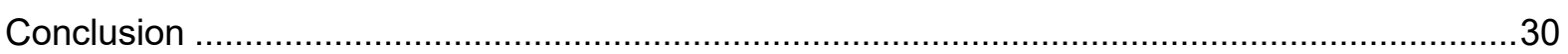

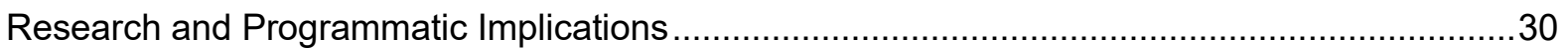

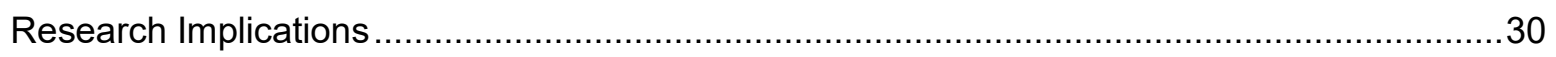

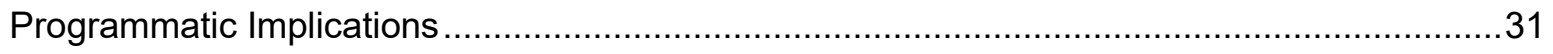

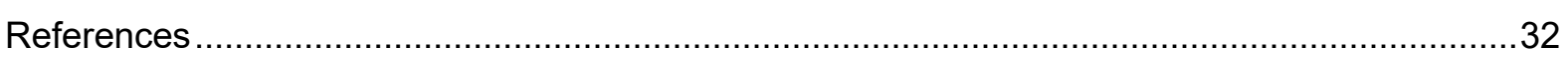

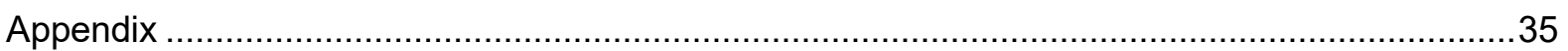




\section{List of Figures}

Figure 1. Map of Nigeria's six geopolitical zones' FGM/C prevalence, MICS 2016-17 ….........2

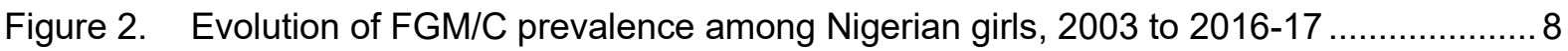

Figure 3. Unadjusted total spatial effect, Fully adjusted total spatial effects, 95\% posterior probability, 95\% posterior probability, 2003 NDHS.................................................. 10

Figure 4. Non-linear effects of Girl's and Mother's age, 2003 NDHS unadjusted model (I) ......11

Figure 5. Non-linear effects of Girl's and Mother's age, 2003 NDHS fully adjusted model (I) .. 11

Figure 6. Non-linear effects of Mother's age, 2007 NMICS unadjusted and fully adjusted models

Figure 7. Unadjusted total spatial effect, Fully adjusted total spatial effects, 95\% posterior probability, 95\% posterior probability, 2007 NMICS

Figure 8. Unadjusted total spatial effect, Fully adjusted total spatial effects, 95\% posterior probability, 95\% posterior probability, 2008 NDHS.

Figure 9. Non-linear effects of Mother's and Girl's age, 2008 NDHS fully adjusted model (III) 15

Figure 10. Unadjusted spatial effect, Fully adjusted spatial effect, 95\% posterior probabilityfor unadjusted spatial effect, 95\% posterior probability for fully adjusted spatial effect, 2011 NMICS

Figure 11. Non-linear effects of Mother's age, Model I and Model III, 2011 NMICS

Figure 12. Unadjusted spatial effect, Fully adjusted spatial effect, $95 \%$ posterior probabilityfor unadjusted spatial effect, $95 \%$ posterior probability for fully observed spatial effect, 2013 NDHS

Figure 13. Non-linear effects of girl's and mother's age, 2013 NDHS unadjusted model (I)...... 19

Figure 14. Non-linear effects of girl's and mother's age, 2013 NDHS unadjusted model (III) $\ldots . . .20$

Figure 15. Unadjusted spatial effect, Fully adjusted spatial effect, $95 \%$ posterior probabilityfor unadjusted spatial effect, $95 \%$ posterior probability for fully observed spatial effect, 2016-17 data

Figure 16. Estimated non-linear effects of mother's age on FGM/C prevalence among girls, MICS 2016-17

Figure 17 . Fully adjusted model (III) and its $95 \%$ posterior probability, pooled data

Figure 18. NonNon-linear effects of mother's age and temporal trend, pooled data .23 
Figure 19. Kaplan-Meier survival curves of timing of FGM/C, by place of residence

Figure 20. Kaplan-Meier survival curves of timing of FGM/C, by region

Figure 21. Kaplan-Meier survival curves of timing of FGM/C, by mother's education 26

Figure 22. Kaplan-Meier survival curves of timing of FGM/C, by religion 26

Figure 23. Kaplan-Meier survival curves of timing of FGM/C, by ethnicity 27

Figure 24. Kaplan-Meier survival curves of timing of $F G M / C$, by FGM/C support. 27

Figure 25. Kaplan-Meier survival curves of timing of FGM/C, by mother's FGM/C status .28 


\section{List of Tables}

Table 1. Sample size of women aged 15-49 years and girls aged 0-14 years for each of the Nigeria DHS and MICS surveys from 2003 to 2016-17

Table 2. Median and inter-quarter (IQR) survival time (years) of predictors of FGM/C among girls in Nigeria (NDHS 2013).

Table A1. Bayesian Geo-additive Multilevel Regression, evidence from the 2003 DHS 40

Table A2. Bayesian Geo-additive Multilevel Regression, evidence from the 2007 MICS

Table A3. Bayesian Geo-additive Multilevel Regression, evidence from the 2008 DHS

Table A4. Bayesian Geo-additive Multilevel Regression, evidence from the 2011 MICS .52

Table A5. Bayesian Geo-additive Multilevel Regression, evidence from the 2013 NDHS .55

Table A6. Unadjusted and adjusted posterior odds ratios (POR) and associated 95\% credible intervals $(\mathrm{Cl})$ from Bayesian Geo-additive hierarchical logistic regression models, using NMICS 2016-17

Table A7. Unadjusted and adjusted posterior odds ratios (POR) and associated $95 \%$ credible intervals $(\mathrm{Cl})$ from Bayesian Geo-additive hierarchical logistic Models using the pooled 2003 to $2016-17$ data 


\section{List of Acronyms}

$\begin{array}{ll}\text { DHS } & \text { Demographic and Health Survey } \\ \text { FCT } & \text { Federal Capital Territory } \\ \text { FGM/C } & \text { Female Genital Mutilation/Cutting } \\ \text { GIS } & \text { Geographic Information System } \\ \text { IQR } & \text { Inter-quartile Range } \\ \text { KM } & \text { Kaplan-Meier } \\ \text { MICS } & \text { Multiple Indicator Cluster Survey } \\ \text { MCMC } & \text { Markov Chain Monte Carlo } \\ \text { MRF } & \text { Markov Random Field } \\ \text { PM } & \text { Posterior Means } \\ \text { POR } & \text { Posterior Odds Ratio }\end{array}$




\section{Acknowledgments}

The authors thank the following reviewers for their insights: Bettina Shell-Duncan of the Department of Anthropology, University of Washington, Seattle, Washington; Caroline Kabiru, Francis Obare, and Jacinta Muteshi of the Population Council, Kenya; and Otibho Obianwu of the Population Council, Nigeria. Additional editorial support was provided by Robert Pursley and Esther Walgwe of the Population Council. 


\section{Executive Summary}

\section{Background}

The practice of female genital mutilation/cutting (FGM/C) has been positioned as a gender and global development issue that national and international organisations must address for girls and women to thrive in good health and enjoy their fundamental rights. Consequently, many efforts have been made to promote the abandonment of the practice. Despite evidence of a decline in $\mathrm{FGM} / \mathrm{C}$, there are significant variations in its prevalence in many sub-Saharan African countries, where the practice persists due to the combined effects of factors among individuals as well as communities. This report presents findings from a study that analysed existing data using Bayesian hierarchical regression tools to examine variations in FGM/C among girls ages 14 and younger in Nigeria according to individual and community factors.

\section{Methods}

A novel Bayesian spatio-temporal regression modelling framework simultaneously accounted for the combined impacts of individual and community risk factors of FGM/C rates in space and time, using six nationally representative datasets. These samples comprised a total of 88,319 daughters of 51,141 women who took part in the Nigeria Demographic and Health Surveys (DHS) and Multiple Indicator Cluster Surveys (MICS) conducted between 2003 and 2016-17. To evaluate geographic variations in $\mathrm{FGM} / \mathrm{C}$ prevalence, robust Bayesian geo-additive logistic models were estimated for each dataset. In addition, these models were fitted to pooled data from all of the surveys to gain more statistical power, improve parameter estimates, and assess temporal trends. This approach examined unobserved spatial effects, socio-demographic predictors, and other factors. These models were implemented with advanced statistical software known as BayesX via its interface in R statistical programming software, R2BayesX. Model parameters estimation were within the Markov Chain Monte Carlo (MCMC) framework, while model fit and complexity assessments utilised deviance information criterion (DIC). Unobserved spatial effects of geographic location were quantified with estimated posterior spatial effects maps and associated 95 percent posterior probability maps. For other individual and community risk factors, estimated posterior odds ratios (PORs) and 95 percent credible intervals (Cls) were reported. Survival analysis techniques were utilised to address data censoring, accounting for the fact a girl who was not cut at the time of a survey could still be cut in future. Kaplan-Meier estimates including median age and interquartile range of age at cutting are reported for some key socio-demographic factors.

\section{Results}

Findings highlight individual-level and community factors that are key to the observed dynamics of FGM/C among girls ages 14 and younger in Nigeria. Apart from the 2003 DHS, in which urban girls were more likely to be cut, as well as the 2007 MICS unadjusted model showing that urban girls were more likely to be cut, girls who lived in rural areas in other survey years had higher likelihoods of undergoing FGM/C than their urban counterparts. Results from the pooled 2003 to 2016-17 data also show a higher likelihood of cutting among rural girls. Prior to 2008, a girl living in Southern Nigeria was more likely to be cut than any Northern counterpart. However, from 2008 girls who lived in the North West geopolitical zone were more likely to be cut than those in the North Central zone. Pooled data show that a girl who lives in the North West or South West geopolitical zones has a higher likelihood of experiencing FGM/C than girls who live elsewhere in the country. This study's approach allowed identification of geographical locations (states) with significantly high unobserved geographical location effects ("hotspots"). Based on the pooled data, hotspots include Edo, Ekiti, Kwara, Niger, Kano, Jigawa, and Bauchi states. 
The results suggest that religion is a key driver of FGM/C in Nigeria. Apart from MICS 2003 results, when an adjusted model showed that girls whose mother's religious affiliation was Christianity were more likely to be cut, findings show, for other survey years, that daughters of Muslim women are more likely to be cut than counterparts whose mothers are Christian. Apart from MICS 2007 and 2008 analyses results, in which formerly married women had a higher likelihood of having their daughters cut, results show that currently married women have a higher likelihood of having their daughters cut than formerly married and never married women, for all survey years and the pooled data.

In terms of ethnicity, in the 2003 DHS, Yoruba or Igbo girls were more likely to be cut than a Fulani girl, while Hausa girls were less likely to be cut. In 2008, Yoruba, Igbo, and Hausa girls had higher likelihoods of being cut than Fulani girls. In 2016-17, however, a Fulani girl was more likely to be cut than counterparts from other ethnic groups. Survival analysis results suggest that 75 percent of cut girls from the Hausa ethnic group were cut at the age of 10, while 75 percent of cut girls of the Yoruba ethnic group were cut at the age of three.

After statistically controlling for other covariates, FGM/C prevalence was higher in poorer households. Apart from 2007, when girls from households in the fourth highest wealth quintile showed a highest likelihood of $F G M / C$, this study finds that girls from poorer householders are more likely to have undergone FGM/C. A girl's likelihood of experiencing FGM/C increased with her age. The likelihood of FGM/C is also higher if a girl is from a monoethnic household. FGM/C is also more likely if the girl's mother is age 35 or older, if the mother has a low level of education, and if the mother does not read newspapers or magazines, or ever watch TV. If a mother is informally employed, or has no job, $\mathrm{FGM} / \mathrm{C}$ is more likely for her daughter, as well as if the mother is older than her husband, or if she has sole decision-making power on how she spends her money or makes large household purchases. ,

The prevalence of FGM/C is also correlated with mothers' own beliefs about FGM/C. For example, daughters of cut women, daughters of mothers who want FGM/C to continue, and daughters of mothers who believe FGM/C will enhance a girl's marriage market value have a higher likelihood of being cut than their counterparts.

\section{Conclusion}

The advanced statistical methods employed in this study allowed the identification of "hotspots" where observed FGM/C prevalence is largely driven by unobserved, geographic-specific factors. This finding calls for further investigation to understand and address these unobserved factors. Overall, FGM/C prevalence has declined in the South, with predominance shifting to the North. The fight against the practice of FGM/C in Nigeria is not yet over, and there is need for unique programmatic interventions to empower women and encourage changes for achieving stable FGM/C abandonment. This report provides concrete, context-specific evidence to assist policymakers and those implementing programmes to design specific interventions for identified FGM/C hotspots and their associated factors. 


\section{Background}

Female genital mutilation/cutting $(\mathrm{FGM} / \mathrm{C})$ is a gender and global development issue that national and international organisations must address for girls and women to thrive and enjoy their fundamental rights (Mediterranean Institute of Gender Studies 2015). Scholars argue that FGM/C is an enduring practice, driven by community and individual factors, and several theories explain why the practice of FGM/C persists despite sustained efforts for its elimination. In this study, attention is focused on the social norms theory, the feminist theory, and the modernisation theory.

The social norms theory explains how social norms influence FGM/C (Mackie 1996). The theory suggests that an individual internalises social rules, following interactions with reference groups or important members of a community. Social norms persist because they are maintained through reciprocal expectations within a reference group (Mackie and Lejeune 2009). Social norms theory suggests that individual behaviour patterns are governed not simply by individual preferences but also by pressure to comply with social norms. In this view, FGM/C persists within a context of competition for marriage, especially in a high social stratum, and in such a context, undergoing FGM/C signals marital fidelity and is a pre-requisite for successful marriage. Accordingly, those who seek to opt out of the practice risk not being married and having illegitimate children (Mackie 1996). Advocates of social norms theory also accept that peer pressure may help explain reliance on cutting. This shift from FGM/C as a requirement for a successful marriage to 'peer pressure' is explained by emerging evidence that the importance attached to marriage has diminished in some countries. For example, a study in the Senegambia showed that most participants did not consider FGM/C a pre-requisite for marriage. Rather, the practice was noted to persist mainly because it was an inter-generational convention signalling that a cut girl or woman had been initiated into the social networks of cut elder women, whose authority they must observe or risk negative social sanctions (Shell-Duncan et al. 2011).

The feminist theory suggests that FGM/C persists because women are denied autonomy and are forced to live in patriarchal structures and be economically dependent (Gruenbaum 2011). The focus of this theory is on the social context in which gender inequality flourishes (Abusharaf 2000, Hayford 2005; Yount 2002). For the feminist theory, FGM/C abandonment means ensuring that women's future security does not rely exclusively on what husbands can provide. Thus, to end FGM/C women must be empowered, and gender equality promoted by questioning policies and practices that restrict women's choices and opportunities in society.

The final approach to understanding FGM/C is the modernisation theory, which argues for the possibility of reducing demand for FGM/C through high educational attainment by girls and women and wider access to economic activities, utilising the media to convey anti-FGM/C messages (Boye 2002; Cloward 2016), and focusing on individual rights and opportunities rather than simply collective rights (Hayford 2005).

These theories have informed interventions to promote the practice's abandonment. However, there are questions about whether the practice is genuinely declining given the resources invested in abandonment interventions. Findings from one report of trends in Nigeria reveal that although FGM/C is declining nationally among girls ages 14 and younger, as well as among women ages 15 to 49 , rates vary by region (Kandala et al. 2019). However, this report's overall statistics were not adjusted for possible confounding factors such as the characteristics of a state where girls resided, along with other individual and community factors, necessitating the use of advanced statistical methodologies to enable simultaneous assessment of the joint impacts of confounders. 


\section{Aims of the Report}

There is a growing need for context-specific multivariate analysis of the data collected in successive surveys in Nigeria to address variations in changes of FGM/C prevalence among girls. A preliminary analysis of data from Nigeria concluded that FGM/C prevalence was decreasing for women ages 15 to 49 , but there was exceptionally high prevalence for girls age 14 and younger (see Figure 1, girls' prevalence in red) (Kandala et al. 2019). Such a conclusion could only be provisional, however, as it did not control for possible confounding factors that might interfere with or confound estimated contributions of affected factors in the observed prevalence of $\mathrm{FGM} / \mathrm{C}$.

Those potential confounders are considered in this study, through the use of statistical techniques that simultaneously control for both individual and community factors, as well as unobserved effects of geographic location and time, in a coherent mixed model framework. One such technique is the use of geo-additive, semi-parametric models controlling for spatial dependence as well as spatial heterogeneity, and potential time-varying linear and non-linear covariates (Kandala et al. 2019, Kandala et al. 2009). One advantage of this approach is that the contributions of unobserved effects from geographic locations of girls on observed FGM/C prevalence can then be quantified and mapped. Then states requiring unique programmatic interventions for elimination of the practice can be identified.

This report aims to shed light on the important issue of whether accounting for the combined influence of individual and community factors decreases the likelihood of FGM/C among girls in Nigeria-and pursues two specific objectives. First, this report examines whether there is a significant correlation between individual as well as community characteristics and FGM/C. Second, it assesses the roles of geographic location and the associated latent factors on the observed FGM/C prevalence to identify and map hotspots where the effects of unobserved geographical location-specific factors on the observed FGM/C prevalence are high.

Figure 1. FGM/C prevalence in Nigeria by geopolitical zones and states, MICS 2016-17

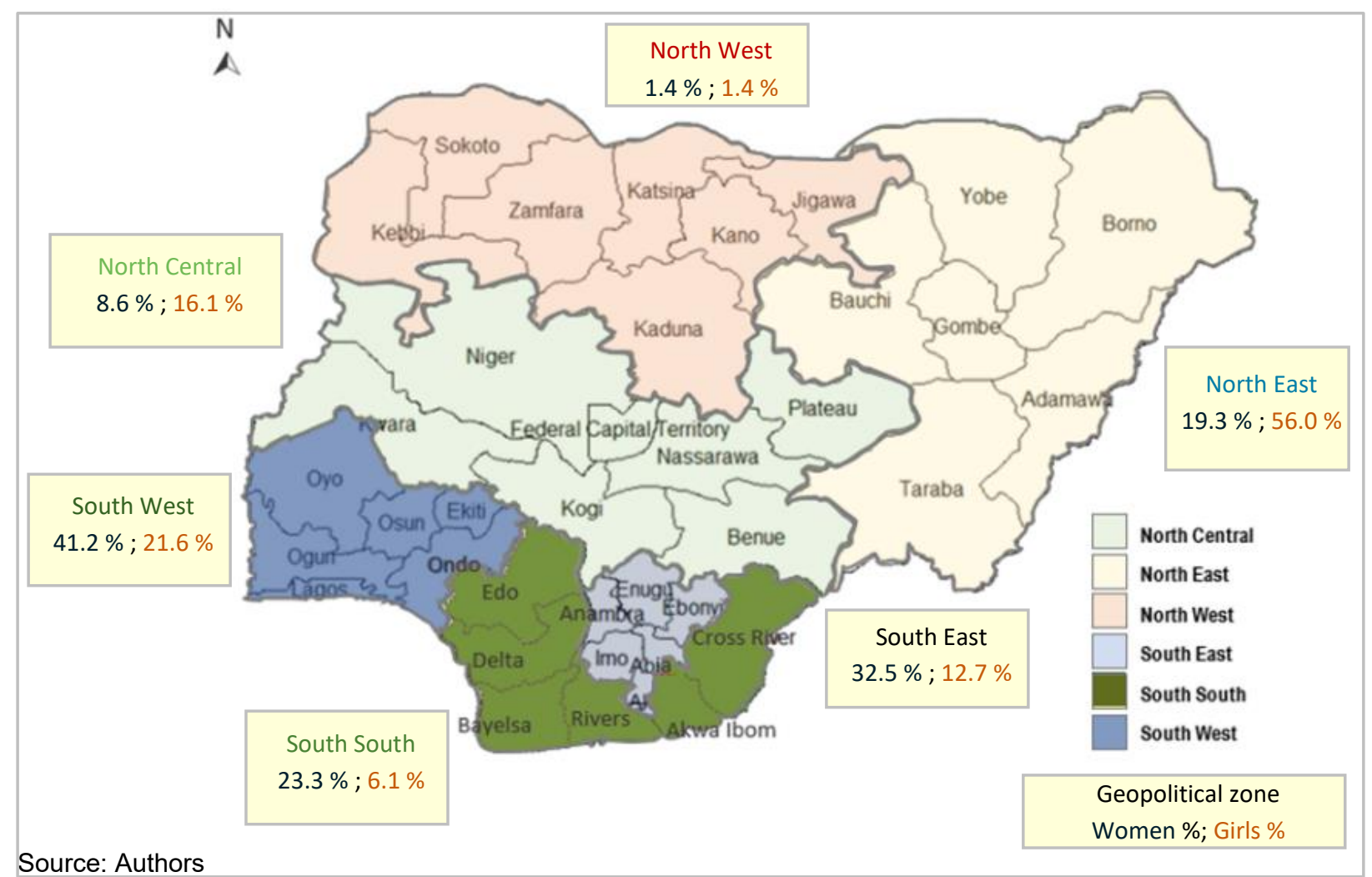




\section{Methods}

\section{Data sources}

The report draws on data collected in successive waves of the Demographic and Health Survey (DHS) and Multiple Indicator Cluster Survey (MICS) from 2003 to 2017 in Nigeria. To date, Nigeria has benefited from six waves each of DHS and MICS, which contain reliable information on FGM/C. Both surveys are nationally representative and cross-sectional, with samples drawn in two-stage cluster sampling. The design of each survey, organisation, sample size and design, questionnaires, and implementation are described in their respective reports (National Bureau of Statistics [NBS] and UNICEF 2008, 2017;; NBS, UNICEF, UNFPA 2013; National Population Commission [NPC] Nigeria and ORC 2004, 2009, 2014). The overall sample sizes for our analysis are reported in Table 1.

Table 1. Sample size of women ages 15 to 49 and girls ages 0 to 14 for each Nigeria DHS and MICS, 2003 to 2016-17

\begin{tabular}{|l|c|c|}
\hline Year/Type of Survey & Women 15-49 years & Girls 0-14 years \\
\hline $\mathbf{2 0 0 3}$ DHS & 1,902 & 3,281 \\
\hline $\mathbf{2 0 0 7}$ MICS & 6,971 & $\mathbf{7 , 7 6 8}$ \\
\hline $\mathbf{2 0 0 8}$ DHS & 13,933 & 17,691 \\
\hline $\mathbf{2 0 1 1}$ MICS & 9,253 & 16,874 \\
\hline $\mathbf{2 0 1 3}$ DHS & 8,558 & 25,176 \\
\hline $\mathbf{2 0 1 6}-17$ MICS & 10,524 & 17,529 \\
\hline TOTAL & $\mathbf{8 8 , 3 1 9}$ & $\mathbf{5 1 , 1 4 1}$ \\
\hline
\end{tabular}

*Note: Prior to 2010, women were asked to provide information about their most recently cut daughters, of any age. This study's samples contained information only on 0 to 14 year-old girls obtained from women who had at least one living daughter. Beginning in 2010, women were asked to provide information on all daughters aged 0 to 14 .

We relied on data collected through core household questionnaires for the relevant period (i.e., 20032017). These are essentially data based on self-reports by women ages $15-49$ who were asked about their own FGM/C status as well as the FGM/C status of their daughters (if any). The details of the FGM/C modules and population sampling have already been discussed elsewhere (Kandala et al. 2019) and are described briefly in the following section.

\section{Sampling design and complexity}

The DHS and MICS utilise two-stage cluster sampling designs, often with over-sampling of smaller domains such as urban areas or certain regions of a country. In the first stage, a random sample of clusters (enumeration areas, villages/communities) is taken. Enumeration areas (EAs) are usually created during national population censuses. At the second stage, a random sample of households within the selected clusters is taken and all women respondents (ages 15 to 49 years) in the sampled households are targeted for individual interviews. Although cluster sampling is a cost-saving measure that eliminates the need to list all the entire households in the administrative level of interest, statistically, it creates analytical problems in that observational units are not independent. Statistical analytical approaches that rely on the assumption of independence of observations are not 
appropriate in such cases, thus requiring a more advanced statistical methodology that allows for dependency between observations.

To overcome these analytical issues, we used the Bayesian geo-additive hierarchical regression modelling approach that examines the spatial variation in $\mathrm{FGM} / \mathrm{C}$ prevalence while simultaneously controlling for the unobserved effects of spatial dependence as well as spatial heterogeneity, and other linear and non-linear (including time-varying) covariates effects.

\section{Outcome variables}

\section{Main variables}

The main outcome variable for the study was whether a woman's daughter age 14 or younger was subjected to FGM/C or not. Responses to the question were coded into a binary variable with the 'yes' category coded 1 (daughter was cut) and 'no' category coded 0 (daughter was not cut).

Survey respondents (mothers) provided information on their daughters including FGM/C status, age at cutting, and age at the time of the survey. For girls not yet subjected to FGM/C at the time of data collection, reference to 'time' means the time from birth to the current age of the girl (i.e., age of the girl at the time of the survey and if at the time of the survey they were not yet cut but younger than 15 , they were censored and considered as girls at risk). This implies that the final FGM/C status of a currently uncut girl is unknown, as she is still at risk and may experience the event in the future.

The following considerations relating to data were taken into account:

- First, the DHS and MICS collect information on current FGM/C status of daughters, which may be different from their final FGM/C status: a girl who is not cut may still be cut in the future. This challenge can be addressed statistically using survival analysis methods in which uncut girls up to age 14 are right censored.

- Second, differences in the way daughter data were collected over time serve as a limitation in terms of the comparability in the sizes of the prevalence estimates between different surveys. Nevertheless, it must be observed that the changes in the FGM/C module overtime have improved in detail and clarity in the way questions are asked and therefore provide more reliable estimates in the recent surveys.

- Third, the different definitions of FGM/C that were adopted by the different surveys conducted in Nigeria may lead to underreporting in the estimates of FGM/C before the 2008 survey. According to Mandara (2004), the main forms of FGM/C in Nigeria include Angurya (scraping of the vaginal orifice) and Gishiri (cutting of the vaginal wall). Both forms of cutting (Angurya and Gishiri) were included in the definition of FGM/C in Kano State in the 2008 DHS. Subsequent DHS surveys explicitly followed the World Health Organization's (WHO) definition of FGM/C (WHO 2008), however, which defines FGM/C as the partial or total removal of the female external genitalia or other injury to the female genital organs for cultural or other non-therapeutic reasons. Earlier surveys (i.e. 2003, 2008 DHS) did not follow this criterion.

\section{Exposure variables}

The main exposure variables included individual and community characteristics of mothers and their daughters as well as information on their geographic locations. We considered mother's age, marital status, ethnicity, level of education as well as that of her husband/partner, geopolitical zone of residence, state of residence, urban-rural residence, religion, and wealth index as a measure of socioeconomic status.

Other variables include women's FGM/C status, women's support for the continuation of FGM/C, women's belief about FGM/C being a religious obligation, and household's ethnic composition. Also 
considered were women's financial independence (employment type), decision-making powers (e.g. over own health care, small and large household purchases), and media exposure.

\section{Statistical Analysis}

\section{Statistical model}

Bayesian geo-additive logistic mixed models assessed geographic variations in the prevalence of FGM/C, examining both spatial effects and individual and other community risk factors. The relevant factors were explored within a simultaneous, coherent Bayesian hierarchical regression framework, using semi-parametric mixed regression models (Kandala et al. 2009). We tested the bivariate and multivariate associations between socioeconomic and demographic factors and FGM/C. At the same time, we assessed state and geopolitical zone variations in the prevalence across Nigeria. We applied these models to analyse the six datasets and one combined dataset that pooled data from 2003 to 2016-17 to gain more statistical power and better precision in parameters estimation and more accurately evaluate trends in FGM/C.

The Bayesian hierarchical framework overcomes two challenges. First, the use of a two-stage cluster sampling strategy in the DHS and MICS data surveys creates an analytical challenge because observational units are not independent. Any statistical analyses that rely on the assumption of independence of observations at the cluster level, such as a standard regression model, are therefore not appropriate. Second, the effects of some covariates such as age, which are treated as strictly linear in a standard approach, are not usually strictly linear in reality.

Hayford (2005) analysed the 1998 Kenya DHS data using hierarchical models, also known as multilevel models, to separately estimate the effect of community and individual risks of FGM/C. While this approach provides unbiased estimates when individual observations are not independent, it does not account for spatial dependency that arise from cluster sampling. In Nigeria the DHS clusters include states close to each other that share common risk factors, and consequently the assumption of independence of state level in Nigeria is not correct as states close to each other are more likely to share similar socio-cultural norms than those farther apart. It therefore makes sense in this study to employ an approach similar to that of Kandala and colleagues (2009) in the analysis of the 2003 Nigeria DHS that accounts for both the spatial dependency and heterogeneity in geographical locations (states) and linear and non-linear (including time-varying) covariates in a Bayesian framework. The unobserved spatial effects of the geographic location were quantified using the estimated posterior odds ratio (POR) and the associated 95 percent posterior probability maps. All models were estimated within a Markov Chain Monte Carlo (MCMC) framework and implemented in $R$ version 3.5.0 using the $R$ interface to BayesX known as R2BayesX (Umlauf et al. 2015).

The modelling techniques are described in more detail elsewhere (Kandala et al. 2009; Kandala et al. 2019). However, a brief framework of the model is given below: it is a common practice in the literature to model the outcome variable FGM/C with a strictly linear predictor,

$$
\eta_{i}=x^{\prime} \beta+w_{i}^{\prime} \gamma+\epsilon_{i}
$$

where the response variable $y$ has mean $E[y \mid]=.\mu$ and is linked to a linear predictor $\eta$ by $\mu=h(\eta)$, where $\gamma$ are unknown parameters to be estimated and the response function $h$ is usually known, and $\epsilon_{i} \sim N\left(0, \sigma^{2}\right)$ for $i=1, \ldots, n$. The standard linear regression model requires a linear relationship between the response variable and the independent variables, normally distributed residuals, minimal correlation between the covariates, and constant variance of the error terms (homoscedasticity). In most practical situations, such as ours, this model is not applicable for the following reasons: First, our data contain continuous covariates, such as age, which cannot be assumed to have a strictly linear effect on the predictor. Second, the assumption of independence will not apply as evidence has shown that our observations (girls' FGM/C status) are spatially and 
temporally correlated. There is therefore need for a model that adequately captures the complex interactions among covariates while simultaneously considering the unobserved location-specific autocorrelation and heterogeneity.

We replace the strictly linear predictor in (1) above with a logit link function with dynamic spatial effects and a geo-additive semi-parametric predictor $\mu_{i}=h\left(\eta_{i}\right)$, such that,

$$
\eta_{i}=f_{1}\left(x_{i 1}\right)+\cdots+f_{p}\left(x_{i p}\right)+f_{\text {spat }}\left(s_{i}\right)+w_{i}^{\prime}
$$

...where, $f_{1}(),. \ldots, f_{p}($.$) are non-linear smoothed effects of the metrical covariates (e.g. respondent's$ age) and $f_{\text {spat }}\left(s_{i}\right)$ is the effect of the spatial covariate $s_{i}=\{1, \ldots, S\}$ representing states and the Federal Capital Territory (FCT), in which case $S=37$. The observation model (2) can include the interaction $f(x) z$ between a continuous covariate $x$ and a binary component of $z$, leading to varying coefficient models, and/or adding a non-linear interaction $f_{1,2}\left(x_{1}, x_{2}\right)$ of two continuous covariates, $x_{1}$ and $x_{2}$. Furthermore, we separately account for spatial autocorrelation and spatial heterogeneity by splitting up the total spatial effect component of $(2) f_{\text {spat }}($.$) into a spatially correlated (structured) effect$ $f_{\text {str }}($.$) and a spatially uncorrelated (unstructured) effect f_{\text {unstr }}($.$) , that is,$

$$
f_{\text {spat }}\left(s_{i}\right)=f_{\text {str }}\left(s_{i}\right)+f_{\text {unstr }}\left(s_{i}\right) \text {. }
$$

In this respect and in accordance with Bayesian paradigm, we choose Markov Random Field (MRF) priors for the structured spatial effects and zero mean Gaussian priors for the unstructured spatial effects. The posterior distribution of interest is then obtained as a product of the likelihood function and the priors. Samples are simulated from the joint posterior distribution using MCMC techniques and inference in a full Bayesian framework. The choice of the MCMC framework was informed by its flexibility and ability to simulate samples from very complex, non-standard posterior distributions.

\section{Multivariate Bayesian geo-additive approach}

\section{Survival analysis datasets and background variables}

An alternative approach to FGM/C data was considered, to account for girls not yet cut at the time of the survey, but at risk of cutting in the future. For this, data of girls' exposure to FGM/C were viewed as survival data, which estimated a girl's likelihood of being cut after exposure to FGM/C-from birth to the age of cutting (for cut girls) or period at which data were collected (uncut girls)—using the 2013 DHS. The 2013 DHS, rather than other datasets, contains all the covariates of interest and information surrounding FGM/C for all daughters ages 14 and younger, thus increasing the reliability of the estimates. For a given girl born in Nigeria who survived until the data were collected, but was not yet subjected to FGM/C at data collection, reference to 'time' is time from birth to the point at which data were available. The variable, status (a binary variable), was coded 1 if a girl had been cut or coded 0 if the girl had not been cut. Explanatory variables include mother's education, religion, ethnicity, household socioeconomic status, region of residence, as well as rural or urban location.

The data of girls' ages at cutting can be described as survival data, but in this case the 'endpoint' relates not to death, but to FGM/C, considered as the failure time (Kandala et al. 2017). At any one point in time, the data include observations in one of the following three categories: 1) those cut, 2) those not cut but will be at some point in the future, and 3) those not been cut who will not be cut.

Survival analysis is a statistical method allowing the inclusion of information on girls who were not cut when data were collected. Duration or survival data cannot generally be analysed by conventional methods such as linear regression, primarily because some durations (girl's age at cutting) are usually right-censored. Meaning the endpoint of interest (e.g. FGM/C) had not occurred at the point of observation, with all that is known about the duration is that it exceeds the observation period. In the present dataset, this applies to all girls who had not undergone FGM/C. These girls' observations or statuses were coded 0 . Another reason why conventional linear regression is not appropriate is that 
survival times tend to have either negative or positive skewed distributions to age $14-$ most FGM/C events occur close to birth (positively skewed) or to age 14 (negatively skewed). A third reason is that time-varying covariates, such as time of year when FGM/C is performed, cannot be handled.

\section{Results}

\section{Key results from Bayesian geo-additive analyses}

In accordance with the theoretical premises of the MCMC framework, results presented are estimates of POR from 20,000 iterations following a burn-in period of 4,000 representing 20 percent of the entire simulated sample. Additionally, we ensured that only every $50^{\text {th }}$ simulated value after burn-in was retained for estimation, known as thinning. Both burn-in and thinning helped improve and optimise the posterior estimates by making the simulated samples seemingly independent.

\section{Evolution of FGM/C prevalence, by state, in Nigeria}

Patterns in the trends of the crude prevalence of FGM/C among girls ages 14 and younger from 2003 to 2016-17 are shown in Figure 2. Note that while making reference to trends in the South West geopolitical region, we excluded Lagos and Ogun states as they had relatively negligible prevalence across the years. In 2003, the South West geopolitical zone experienced the highest prevalence of between 62 percent (Osun state) and 69 percent (Oyo state), followed by Kwara state (a North Central state and a neighbouring state to Oyo, Osun, and Ekiti states) with FGM/C prevalence of 60 percent. Apart from Imo state (FGM/C prevalence 41\%), other states in the South East and South South geopolitical zones experienced prevalence of less than 30 percent. No northern states in 2003 had a prevalence of more than 16 percent except Kwara. In 2007, a relative decline in FGM/C prevalence among girls 14 and younger was observed across the southern regions, with prevalence in South West ranging from 49 percent in Oyo state to 61 percent in Ekiti state. Prevalence in Kwara and Imo states also declined to 49 percent and 36 percent, respectively. At the same time, other states in the South East and South South had a prevalence of less than 25 percent, while no northern state, apart from Kwara state, had a prevalence of more than 17 percent, with a majority having less than one percent. 
Figure 2. Evolution of FGM/C prevalence among Nigerian girls ages 0 to 14 in the 36 states and FCT, from 2003 to 2016-17-high prevalence indicated by bright red
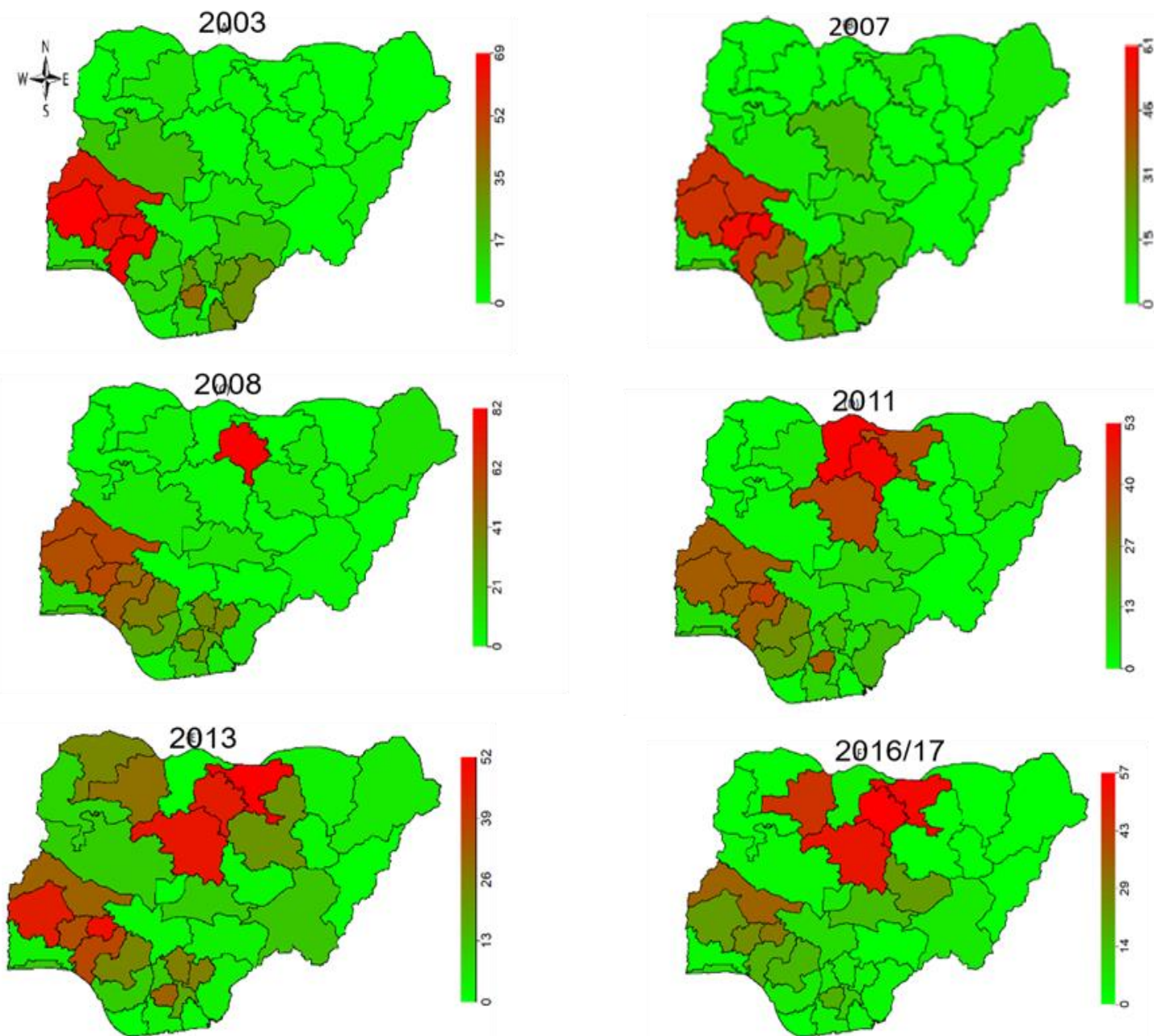

An emerging trend of high prevalence of up to 82 percent was found in the North West state of Kano in 2008, while all South West states had a prevalence of less than 60 percent. At the same time, prevalence increased slightly in the South East states of Ebonyi (37\%), Enugu (39\%), and Abia (30\%), and the South South state of Edo (41\%) in 2008, while no other northern state, with the exception of Kwara (59\%), had a prevalence exceeding 10 percent.

In 2011, prevalence declined further in the South West, with Ekiti state (40\%) having the region's highest prevalence. Also, apart from Imo state $(33 \%)$ and Edo state $(23 \%)$, other states within the South East and South South experienced further decline to less than 20 percent. Although a decline to 51 percent was observed in Kano state, $\mathrm{FGM} / \mathrm{C}$ prevalence was seen to have increased drastically in other neighbouring states of Kaduna (38\%), Katsina (53\%), and Jigawa (37\%), with the rest of the Northern states, apart from Kwara state (33\%), having prevalence of not more than 10 percent.

Additionally, in 2013, FGM/C prevalence in the South West was still less than 40 percent, except in Ekiti $(49 \%)$ and Oyo (45\%) states, while Imo state (32\%) remained the only South East state, along with South South geopolitical zones with a prevalence of more than 30 percent. More variations in prevalence were observed in the north, as prevalence in Kano, Kaduna, and Jigawa states was 45 percent, 47 percent, and 52 percent, respectively, in 2013. FGM/C prevalence in the North East state of Bauchi (neighbour of Jigawa and Kano states) increased to 22 percent in 2013, however. 
Figure 2 further shows that by 2016-17 prevalence in all southern states was 30 percent or lower, while prevalence remained high in the northern states of Kano (57\%), Kaduna (51\%), and Jigawa (55\%). While prevalence in Bauchi and Katsina states decreased drastically, to less than one percent, FGM/C prevalence in Plateau (North Central) and Zamfara (North West) states increased drastically, to 22 percent and 45 percent, respectively.

\section{Bayesian hierarchical geo-additive logistic regression models}

\section{Demographic and Health Survey (DHS)}

Results from the Bayesian geo-additive regression models using 2003 DHS data are shown in Table A1 (Appendix). Girls in urban areas were more likely to be cut than those in rural areas. Girls who lived in southern Nigeria were more likely to undergo FGM/C than their counterparts in other regions. Unadjusted POR, as reported under Model I in Table A1, show that a girl from South West was about 2.54 times more likely to be cut than a girl from the North Central, while girls from South South, North East, and North West had lower likelihoods of being cut. After adjusting for other confounders (Model III), however, girls from the South West and the South South were 3.6 times and 1.7 times, respectively, more likely to undergo FGM/C than a girl in the North Central.

The unadjusted model shows that a girl with a Muslim mother had a lesser likelihood of being cut than a girl with a Christian mother. After accounting for potential confounders (models II and III), the likelihood of being cut was much higher for girls with a Muslim mother. The likelihood of being cut was higher for girls from households in the two poorest wealth quintiles compared to those in the middle quintile. A girl whose mother never married, or was formerly married, was less likely to be cut than a daughter of a currently married woman. A girl born to a Yoruba mother was more likely to be cut than girls from other ethnic groups. A girl's likelihood of being cut was higher when her mother was cut (POR $>17$ for all three models), or when her mother believes $F G M / C$ is required by religion, or if her mother supported FGM/C continuation. Similarly, girls were more likely to be cut if their mothers believed that men would want FGM/C to continue.

The estimated posterior maps for unobserved geographic-specific effects indicate highest risk states by bright red, while pale green marks states with lowest FGM/C risk states in terms of geographic location. On the probability maps, black indicates significantly high risk states, white indicates significantly low-risk states, while grey denotes states with estimated risks that are not significant. Figure 3 (following page) shows the estimated unobserved total spatial effects on FGM/C for states in 2003, for the unadjusted model (A) and fully adjusted model (B), as well as their corresponding 95 percent posterior probability maps in (C) and (D), respectively. Throughout this report, unadjusted map simply refers to the spatial effects map obtained from the model that only considered the effects of unobserved state-specific factors on the observed FGM/C prevalence, without taking other potential confounders into account. Fully adjusted model maps are spatial effects maps obtained from the fully adjusted model (Model III).

The unadjusted maps from Model I ( $A$ and $C$ ) show significantly higher effects of geographic location for observed FGM/C prevalence in the South West states of Osun, Oyo, and Ondo. There were also significantly higher effects of geographic location on observed prevalence in the North Central states of Kwara, Niger, and Benue, the South South states of Cross River, Akwa lbom, Delta, and Edo, and the South East states of Ebonyi, Enugu, Anambra, Imo, and Abia, providing a clearer picture of state variability. After adjusting for other confounders in the fully adjusted model (Model III), however, geographic locations had significantly high effects on observed FGM/C prevalence only in Benue, Cross River, Imo, and Adamawa states - with the observed FGM/C prevalence in these states largely due to unobserved effects of their geographic location. 
Figure 3. (A) Unadjusted total spatial effect, (B) fully adjusted total spatial effects, (C) $95 \%$ posterior probability for (A), and (D) 95\% posterior probability for (B), 2003 DHS
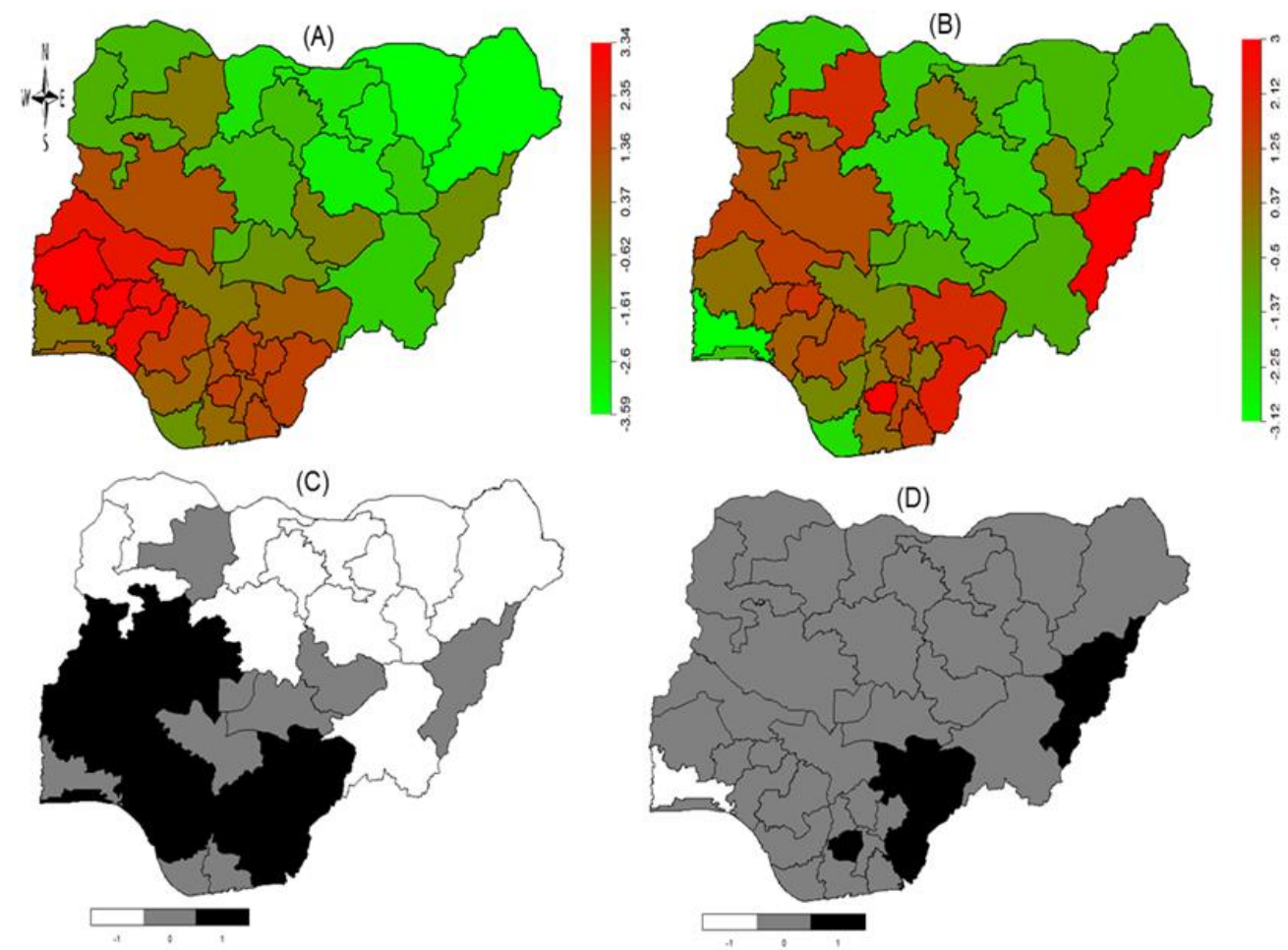

A mother's education was inversely associated with her daughter's likelihood of being cut. Specifically, a girl whose mother attained higher education was least likely to experience FGM/C. A similar relationship was found for the education level of a mother's husband or partner: Daughters of women with husbands or partners with only a primary education had a greater likelihood of being cut than daughters of women with more highly educated husbands or partners. Girls born to women who believed that a man is justified for beating his wife, such as when she denies him sex, were more likely to be cut than their counterparts whose mothers believed otherwise.

Girls whose mothers did not work, and girls whose mother's husband or partner had no formal employment, were more likely to be cut than girls whose mothers had paid jobs and those whose mothers' husbands or partners were employed. The DHS 2003 analyses further suggests that the longer a woman had lived in a community, the more likely it would be for her daughter to be cut. Girls whose mothers had resided in a given location continuously for at least one year were more likely to be cut than those whose mothers had not lived in same location for up to one year. Mothers' media exposure was also associated with their daughters' FGM/C status. For example, girls whose mothers listened to radio or read a newspaper at least once a week were less likely to be cut.

Non-linear effects of mothers' and girls' ages, for both the unadjusted model (Model I) and fully adjusted model (Model III), are shown in figures 4 and 5, respectively. Both models show that a girl's likelihood of being cut increased as both her age and that of her mother increased. The effect of a mother's age on her daughter's likelihood of FGM/C was less pronounced when all other factors were taken into account in the fully adjusted model, Model III, however (Figure 5, left panel). 
Figure 4. Non-linear effects of girl's (left) and mother's (right) age, 2003 DHS unadjusted model (Model I)
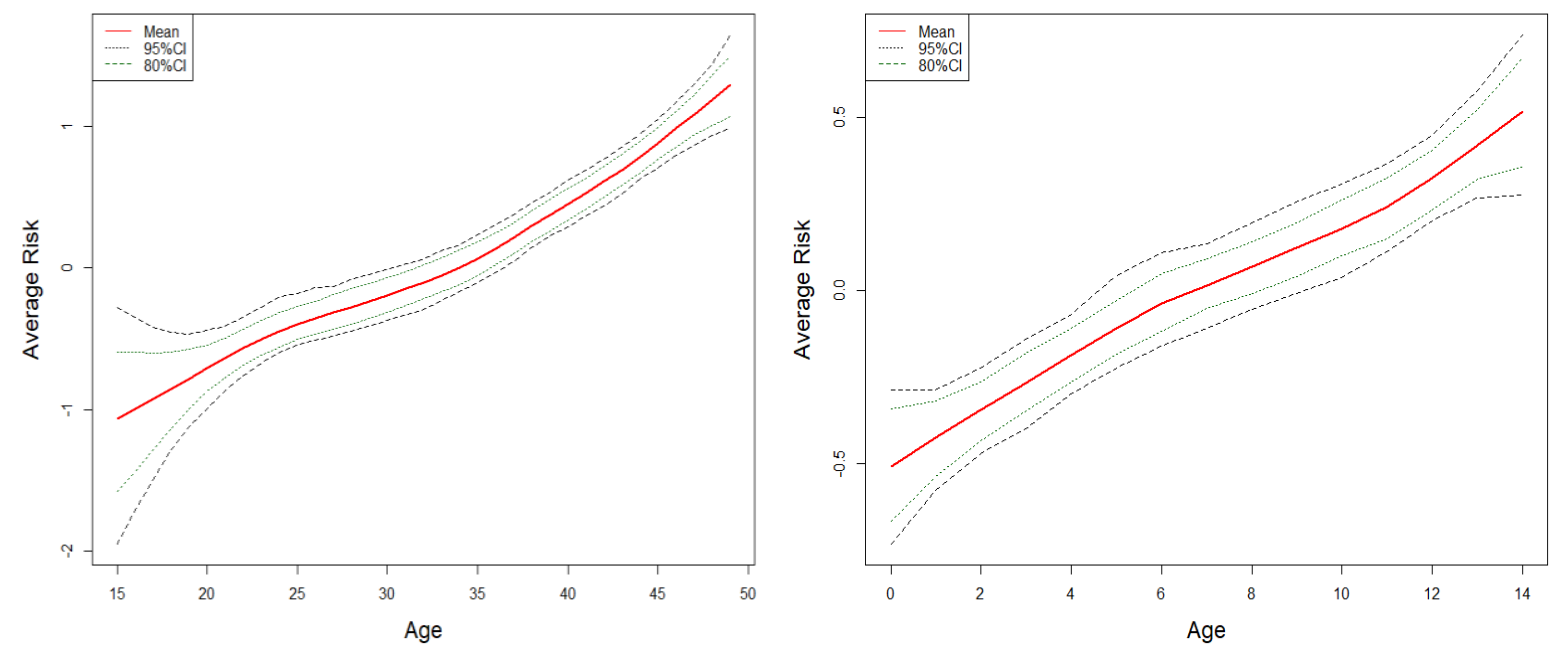

Figure 5. Non-linear effects of girl's (left) and mother's (right) age, 2003 DHS fully adjusted model (Model I)
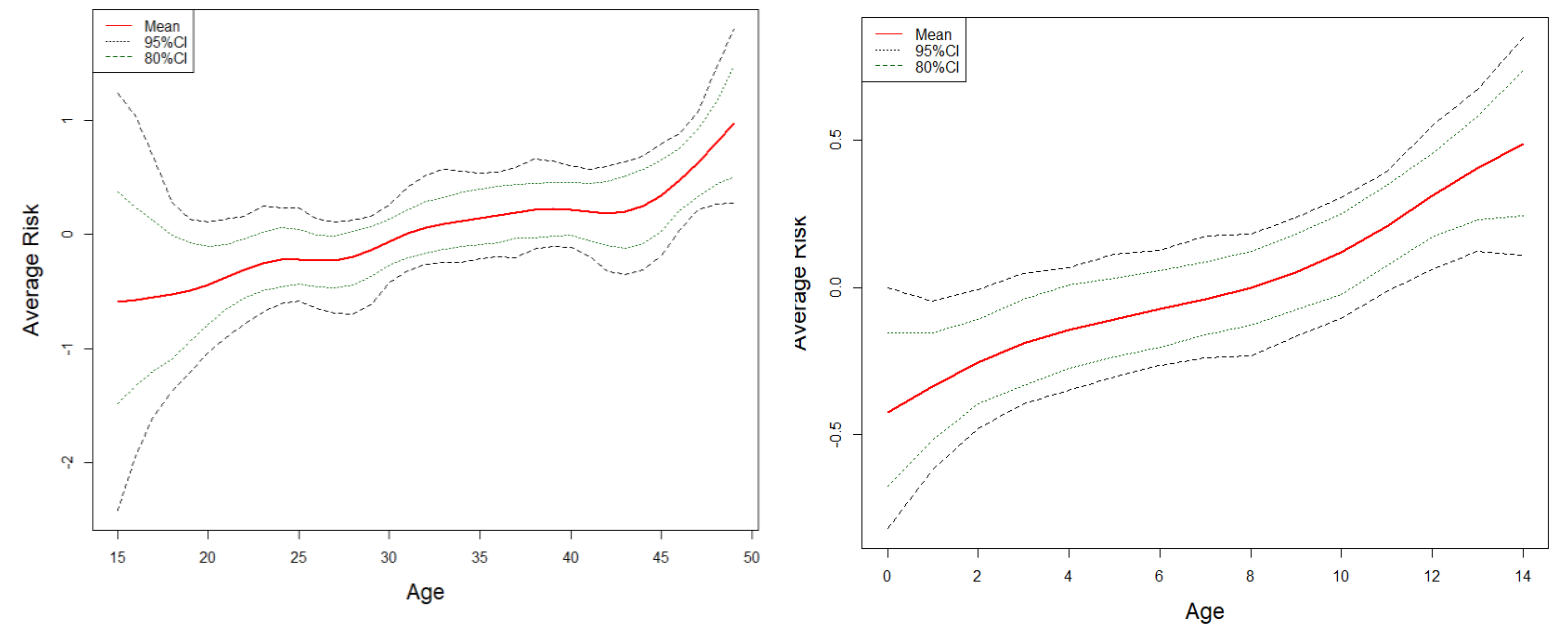

2007 Multiple Indicator Cluster Survey (MICS)

Results from the Bayesian geo-additive regression analysis using 2007 MICS data are shown in Table A2 (Appendix). The unadjusted model (Model I) shows that living in an urban area increased FGM/C likelihood, but after adjusting for other potential confounders (including geographic location) the influence of type of residence was no longer significant. Girls who lived in Southern regions had a higher likelihood of undergoing FGM/C than those in northern Nigeria. In particular, girls in South West were most likely to be cut than girls who lived elsewhere in the country. A girl's likelihood of FGM/C was positively associated with socioeconomic status. Results from Model I show that a girl from a household in the second highest wealth quintile was at least 1.36 times more likely to be cut than a counterpart from a household in the middle wealth quintile. Daughters of formerly married women had higher chances of being cut with unadjusted POR of 1.4 (95\% $\mathrm{Cl}=1.12,1.76)$. A mother's FGM/C status was significantly associated with her daughter's FGM/C status, with girls whose mothers had been cut at least 19.31 times more likely to be cut than girls whose mothers who had not been cut. 
Results also show a high likelihood of cutting among girls whose mothers were younger or same age as their husbands, compared to those who were older than their husbands.

The non-linear effects of mother's age, for Model I (unadjusted) and Model III (fully adjusted), are shown in Figure 6. An increase in mother's age increased the likelihood of her daughter's FGM/C, for both models. The graph from the fully adjusted model (right panel) further shows that from age 25 the likelihood of a girl being cut increased steadily with her mother's age.

Figure 6. Non-linear effects of mother's age, 2007 MICS unadjusted model (left) and fully adjusted model (right)
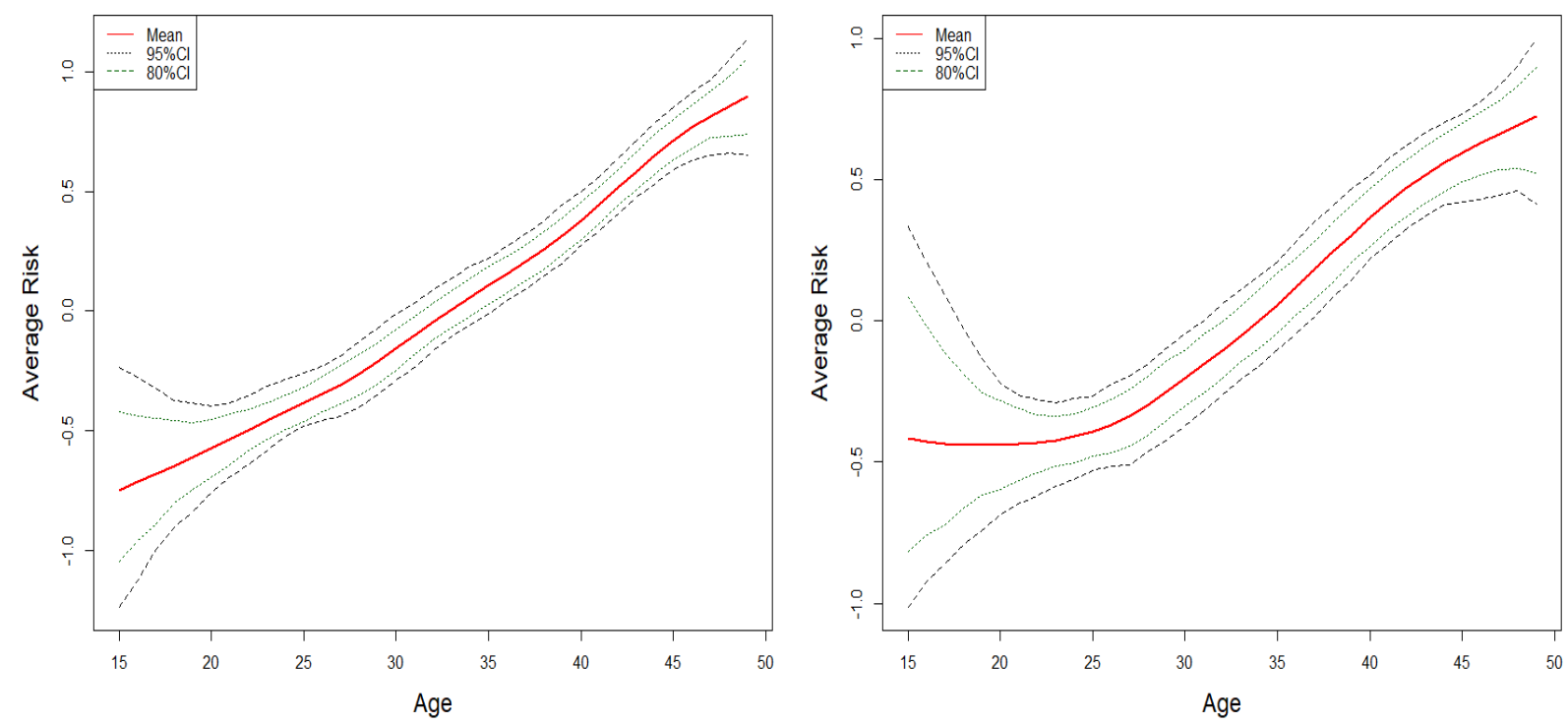

Figure 7 shows the (A) unadjusted and (B) fully adjusted latent spatial effects on observed FGM/C prevalence in all 36 states and FCT, with the corresponding 95 percent posterior probability maps (C) and (D) for the unadjusted and fully adjusted models, respectively, all obtained a posteriori from 2007 MICS data analyses. The maps show unadjusted significantly high-risk states where observed FGM/C prevalence was largely due to unobserved state-specific factors. These unadjusted high-risk states include all South West states besides Ogun, Kaduna state in North West, Benue and Kwara states in North Central, and all South East and South South states besides Akwa Ibom and Bayelsa. After adjusting for other potential confounders, only Kaduna and Kwara remained as significantly high-risk states where unobserved state-specific factors were key drivers of the observed FGM/C prevalence. 
Figure 7. (A) Unadjusted total spatial effect, (B) fully adjusted total spatial effects, (C) $95 \%$ posterior probability for (A), (D) 95\% posterior probability for (B), 2007 MICS
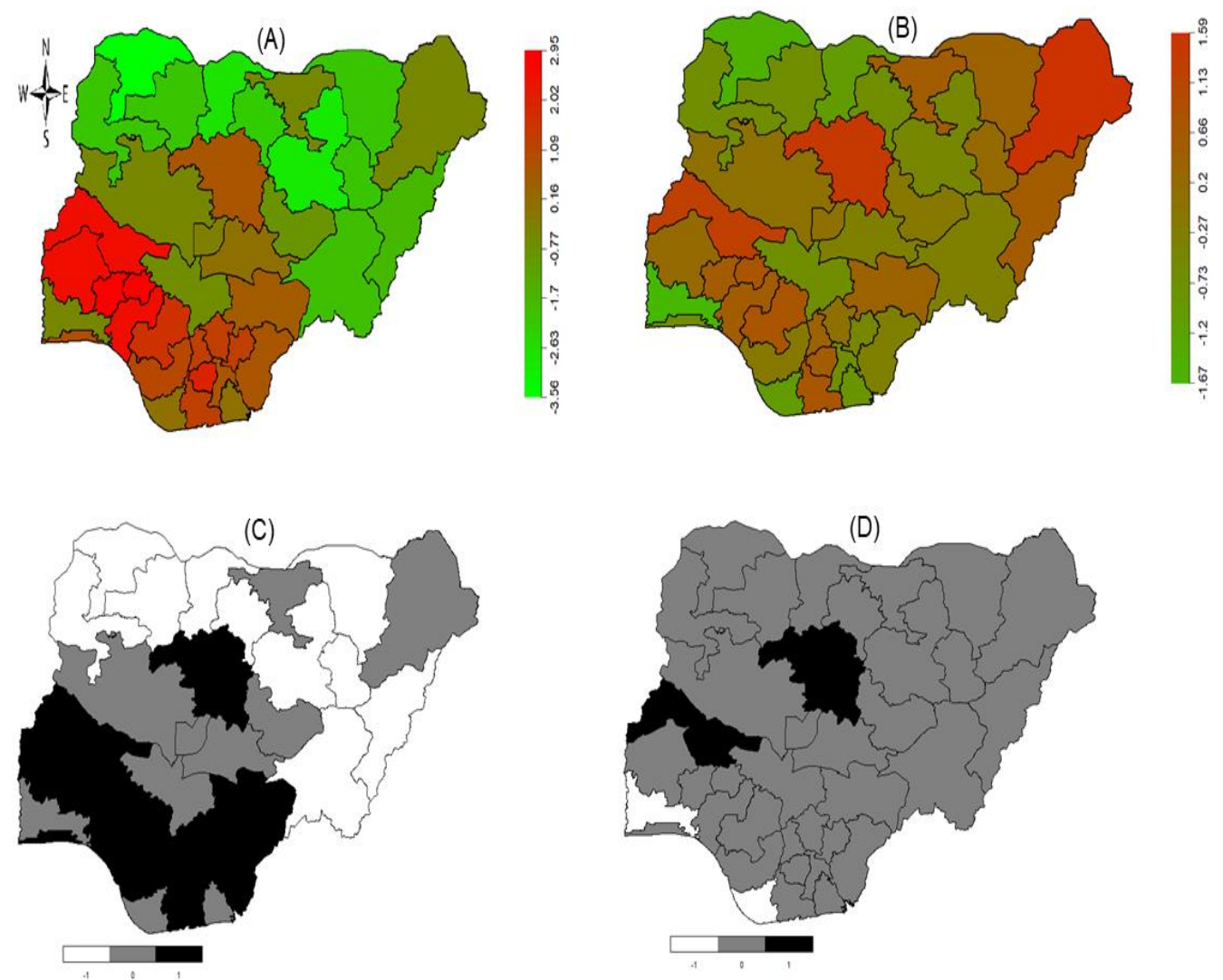


\section{Demographic and Health Survey (DHS)}

Results of the Bayesian regression model analyses of the 2008 DHS are in Table A3 (Appendix). The results show that a girl residing in an urban area was less likely to be cut than a girl in a rural area. Girls in the three geopolitical zones in southern Nigeria, especially in South West, had a higher likelihood of being cut than their northern counterparts. The chances of being cut were higher for girls whose mothers were Muslim than for counterparts with a Christian mother. Girls from households in the second poorest wealth quintile were slightly more likely to be cut than girls from households in the middle wealth quintile. A daughter of a formerly married woman had a higher likelihood of being cut than a girl whose mother was currently married. The likelihood of being cut was highest for girls of Yoruba ethnicity than for Fulani girls, with unadjusted POR of $3.85(95 \% \mathrm{Cl}=3.12,4.72)$ and fully adjusted POR of $1.22(95 \% \mathrm{Cl}=0.79,1.89)$.

A girl's unadjusted likelihood of FGM/C increased by 22.06 times if her mother had been cut, compared with girls whose mothers were not-and likelihood remained even after adjusting for other potential confounders in the fully adjusted model. A girl whose mother supported FGM/C's continuation was at least 4.87 times more likely to be cut than a girl whose mother who would like FGM/C stopped. A woman's beliefs about FGM/C's perceived benefits, as well as her religious inclinations, were associated with the likelihood of her daughter undergoing FGM/C. Compared to girls whose mothers believed otherwise, the likelihood of a girl being cut was significantly higher if her mother believed that being cut increases a girl's value in the marriage market (fully adjusted $\mathrm{POR}=2.41 ; 95 \% \mathrm{Cl}=1.99,2.94$ ), as well as promotes her cleanliness (fully adjusted POR $=1.39 ; 95 \%$ $\mathrm{Cl}=1.15,1.69$ ), enhances a daughter's social acceptance in the community (fully adjusted $\mathrm{POR}=1.91$; $95 \% \mathrm{Cl}=1.63,2.23$ ), promotes her virginity or prevents pre-marital sex (fully adjusted POR $=2.02 ; 95 \%$ $\mathrm{Cl}=1.73,2.41$ ), and enhances sexual pleasure for men (fully adjusted $\mathrm{POR}=1.96 ; 95 \% \mathrm{Cl}=1.50,2.59$ ).

As shown in Table A3, a girl's vulnerability to FGM/C decreased as her mother's education increases, and women with no education having the highest likelihoods of cut daughters. Daughters of women whose husbands were formally educated were least likely to undergo FGM/C.

Women who jointly make decisions about large household purchases with their husbands, as well as those whose husband or someone else makes the decisions about small household purchases, were more likely to have a cut daughter than women who make such decisions on their own. Results from the unadjusted model (Model I) show that women who were younger or of the same age as their husband were more likely to have cut daughters than women who were older than their husbands. After adjusting for other confounders in models II and III, the effect of age difference between a woman and her husband on a daughter's likelihood of undergoing FGM/C was no longer significant.

Unadjusted PORs show that women who work throughout the year were more likely to have a cut daughter than women who only work seasonal jobs or during certain times of the year, but this association was not significant after adjusting for other potential confounders in models II and III.

Girls from a polyethnic household had lower likelihoods of being cut than girls from monoethnic households. The unadjusted results from the 2008 DHS data analyses show that women who never read newspapers or magazines or watch television were more likely to have cut daughters than those exposed to these media, while women who never listen to radio were less likely to have cut daughters. After adjusting for other potential confounders in the fully adjusted model, the effect of media exposure became non-significant.

Figure 8 (following page) shows (A) unadjusted and (B) fully adjusted latent spatial effect maps with corresponding 95 percent posterior probability maps (C) and (D), respectively. The unadjusted map (A), along with its 95 percent posterior probability map (C), show that the South West states of Oyo, Osun, Ondo, Lagos, and Ekiti, the South East states of Abia, Anambra, Ebonyi, Enugu, and Imo, the South South states of Rivers, Delta, and Edo, and Kwara state in North Central -_ Kano state emerged 
as the only significantly high risk North West state in which observed FGM/C prevalence was largely due to unobserved state-specific factors. After adjusting for other potential confounders, unobserved location-specific factors were significant only for Edo, Kwara, Kano, Borno, and FCT.

Figure 8. (A) Unadjusted total spatial effect; (B) Fully adjusted total spatial effects; (C) $95 \%$ posterior probability for (A); (D) 95\% posterior probability for (B), 2008 DHS
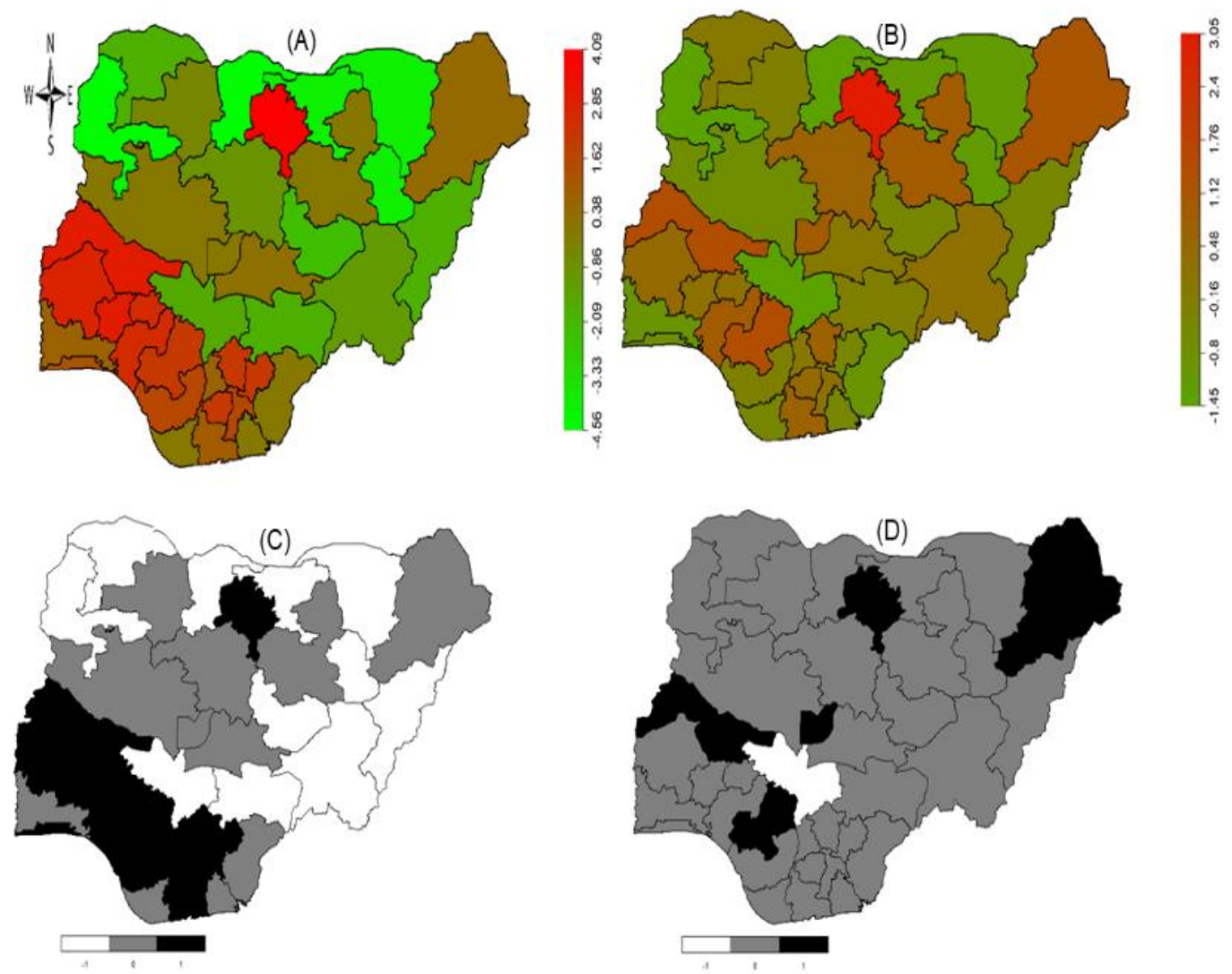

Figure 9 shows that, as both a girl's and her mother's ages increased, a girl's fully adjusted likelihood of FGM/C also increased: Older girls had a higher likelihood of being cut than younger girls. Similarly, older mothers had a higher likelihood of having cutc daughters than younger mothers.

Figure 9. Non-linear effects of mother's (left) and girl's (right) age, 2008 DHS fully adjusted model (Model III)
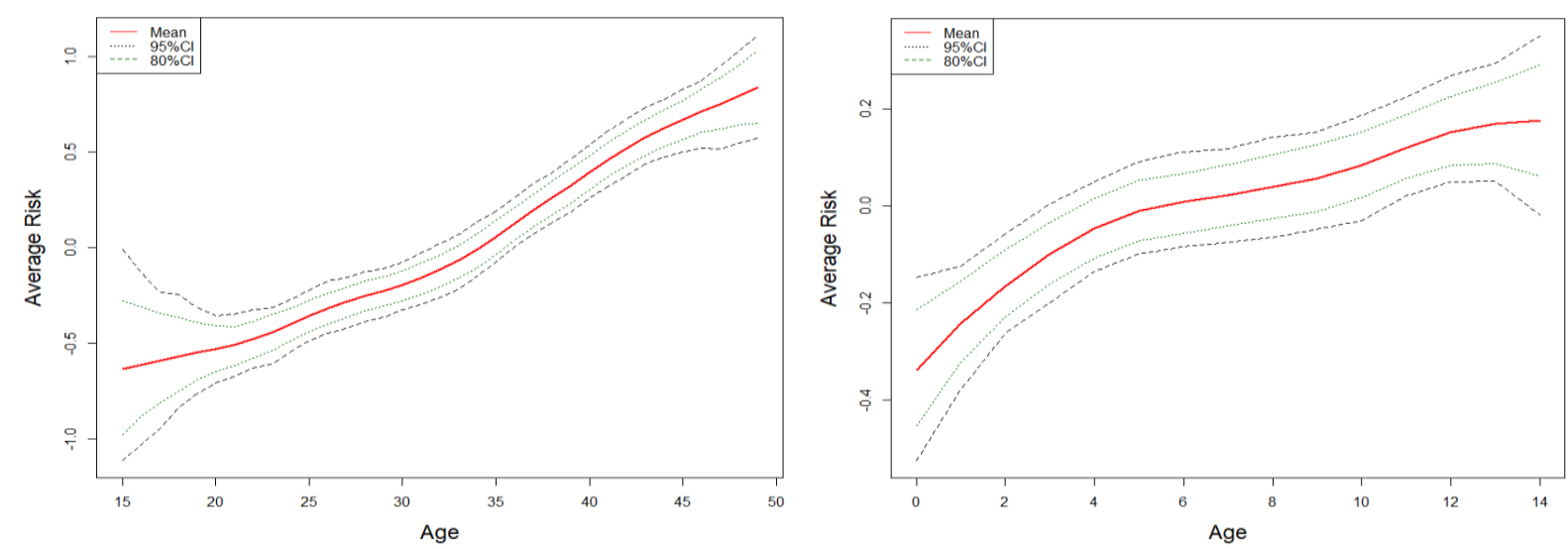
The results of the Bayesian regression analyses of the 2011 MICS are presented in Table A4 (Appendix). Latent spatial component effects are displayed in Figure 10: The unadjusted model (Model I) shows that type of residence was not associated with a girl's FGM/C likelihood. After accounting for other possible confounders, girls who live in urban areas were less likely to be cut than girls who lived in rural areas.

Girls in the North West or South West were more likely to undergo FGM/C than girls in other zones. Girls from households in the richest wealth quintile were less likely to be cut than girls from poorer households. In terms of religion, girls whose mothers were Christians were less likely to be cut than girls whose mothers were Muslim, traditionalist, or of another religion.

The unadjusted model shows that daughters of currently married women were more likely to be cut than daughters of women either formerly married or never married. After adjusting for other potential confounders in Model III, the effect of mother's marital status became non-significant. Women older than their husbands were less likely to have their daughters cut than mothers either younger or the same age as their husbands, in all three models. Furthermore, likelihood of cutting was lowest among daughters of women with more than secondary education. The association between mother's education and daughter's FGM/C status was significant both in the unadjusted and adjusted models.

Girls born to a mother who had been cut, as well as girls whose mothers wanted FGM/C to continue, had a higher likelihood of undergoing FGM/C. Women who justified wife beating (when a wife argues with her husband or denies him sex) were more likely to have their daughters cut than those who believed otherwise. This association was significant both in the unadjusted and adjusted models.

Figure 10 shows the unobserved spatial effects maps for the (A) unadjusted space and (B) fully adjusted model, as well as the 95 percent posterior probability maps for $(C)$ and $(D)$, respectively. The unadjusted spatial effects map shows increased likelihood of FGM/C in the North West states of Katsina, Kano, Jigawa, and Kaduna, where prevalence was largely due to unobserved locationspecific factors. Other regions where girls had a significantly higher likelihood of FGM/C were South West (Oyo, Osun, Ekiti, and Ondo), South South (Delta and Edo), South East (Enugu and Imo), and North Central (Kwara). Unobserved geographic-specific factors significantly influenced observed FGM/C prevalence in Kwara, Jigawa, Plateau, Bornu, and Yobe states, after adjusting for other potential confounders. 
Figure 10. (A) Unadjusted spatial effect, (B) fully adjusted spatial effect, (C) $95 \%$ posterior probability for unadjusted spatial effect, (D) $95 \%$ posterior probability for fully adjusted spatial effect, 2011 MICS
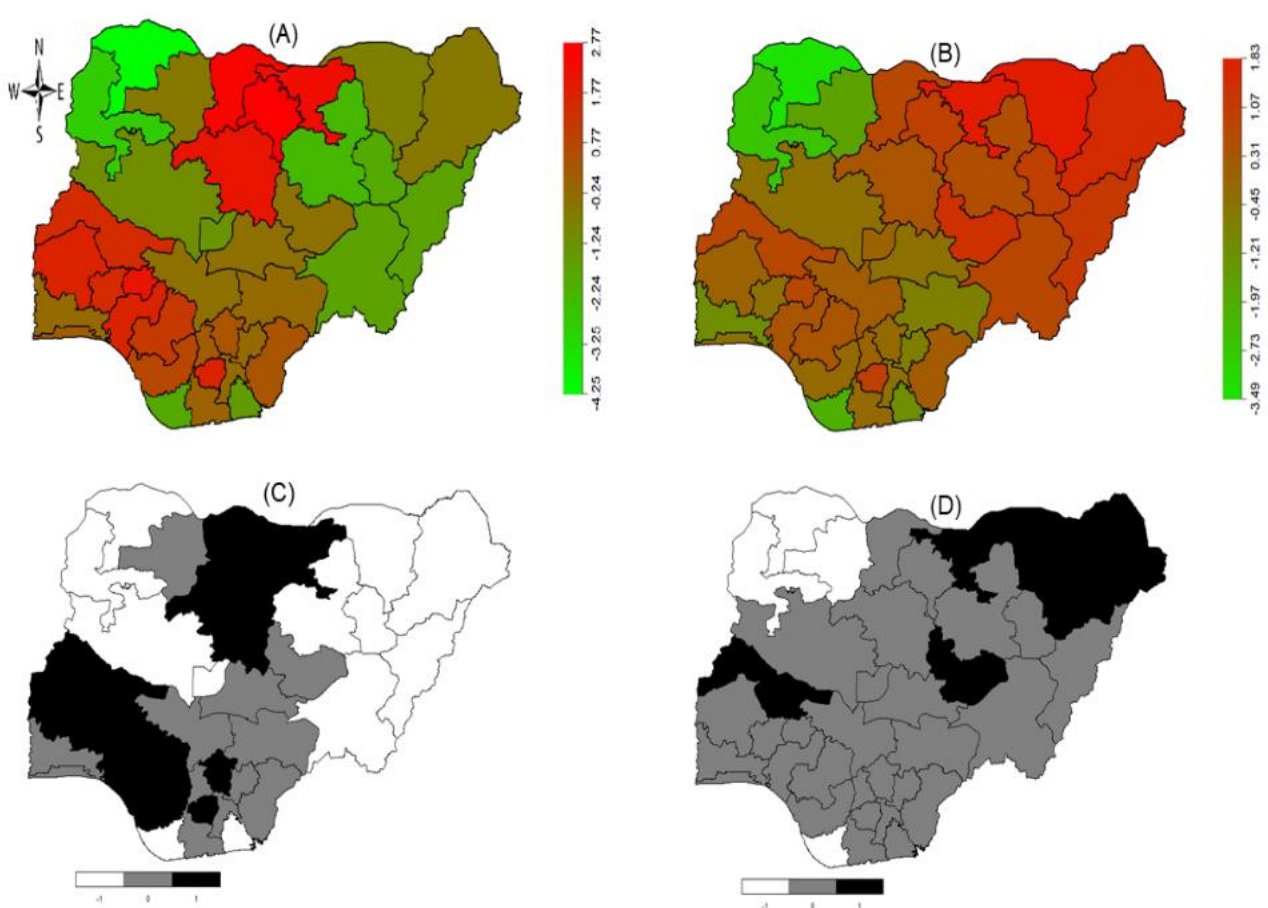

Effect of mother's age was examined by assuming a non-linear relationship between mother's age and her daughter's FGM/C status. Results from the unadjusted model (Figure 11, left) show that as a mother's age increased, from 15 to 25 years, her daughter's likelihood of being cut steadily decreased.

Figure 11. Non-linear effects of Mother's age from Model I (left) and Model III (right), 2011 MICS
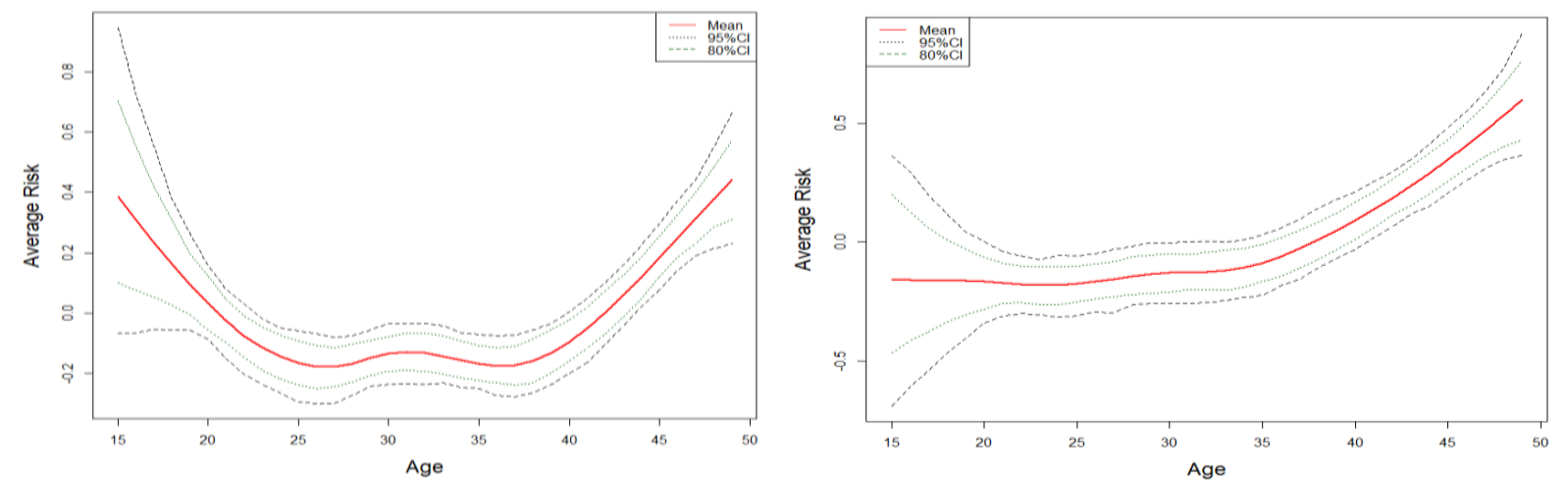

A woman's age did not influence her daughter's likelihood of FGM/C if the mother was between 25 and 37 years old. Daughters of women ages 40 to 49 had increased likelihoods of being cut. The fully adjusted model (Figure 11, right) shows that a girl's likelihood of being cut increased among girls whose mothers were 35 years of age and older.

\section{Demographic and Health Survey (DHS)}

The results of the Bayesian geo-spatial regression model for the $2013 \mathrm{DHS}$ are summarised in Table A5 (Appendix). Urban girls were less likely to be cut than their rural counterparts. Compared to their North Central counterparts, girls from North West, South West, and South East were more likely to be cut. Both the unadjusted and adjusted models show that girls with Muslim mothers were more likely 
to be cut than their counterparts with Christian mothers. Compared to girls from households in the middle wealth quintile, those in the two poorest household quintiles were more likely to be cut, but the difference was not statistically significant in the fully adjusted model. Yoruba and Hausa girls were more likely to be cut than their Fulani counterparts.

Daughters of cut mothers were more likely to have undergone FGM/C than those whose mothers were uncut. Similarly, daughters of women who wanted FGM/C to continue were more likely to be cut than those whose mothers favoured discontinuation. Girls whose mothers believe that FGM/C is a religious requirement were more likely to be cut than girls whose mothers do not believe $F G M / C$ is a religious requirement. In both unadjusted and adjusted models, daughters whose mothers with more than secondary education were significantly less likely to be cut than daughters whose mothers had less education.

Daughters of women who make some key household decisions, solely and independently, were less likely to be cut. For example, a woman who has final say for large household purchases was less likely to have a cut daughter than a woman living in a household where such decisions were made by her husband, or someone else. A woman with a formal occupation was also less likely to have a cut daughter than her counterparts with informal occupations.

Girls whose mothers were in a polygamous union were more likely to be cut than their counterparts. This association was no longer significant, however, after controlling for other potential confounders. A girl born in a polyethnic household (i.e. with parents from different ethnic groups) was less likely to be cut than a counterpart from a monoethnic household. Women who read newspapers or magazines and watched television were less likely to have cut daughters than those not exposed to these media. Women who listened to the radio less than once a week were more likely to have cut daughters, though, than their counterparts who did not listen to the radio at all.

Figure 12 shows $(A)$ unadjusted and $(B)$ fully adjusted latent spatial effects of geographic location on girls' FGM/C status, based on the 2013 DHS. Figure 12 also shows 95 percent posterior probability maps (C) and (D) that correspond to the unadjusted and fully adjusted spatial effects maps. The unadjusted maps show significantly high risk states in both the north and south. There were significantly high unobserved location-specific effects in the South West states of Oyo, Osun, Ondo, and Ekiti, the South South state of Edo, the South East states of Ebonyi, Enugu, and Imo, the North Central state of Kwara, North West states of Sokoto, Zamfara, Kaduna, Kano, and Jigawa, and the North East state of Bauchi. After adjusting for other potential confounders, location-specific effects were only significant for Taraba, Zamfara, Kano, Kaduna, Jigawa, and Bauchi states. 
Figure 12. (A) Unadjusted spatial effect, (B) fully adjusted spatial effect, (C) $95 \%$ posterior probability for unadjusted spatial effect, (D) $95 \%$ posterior probability for fully observed spatial effect, 2013 DHS
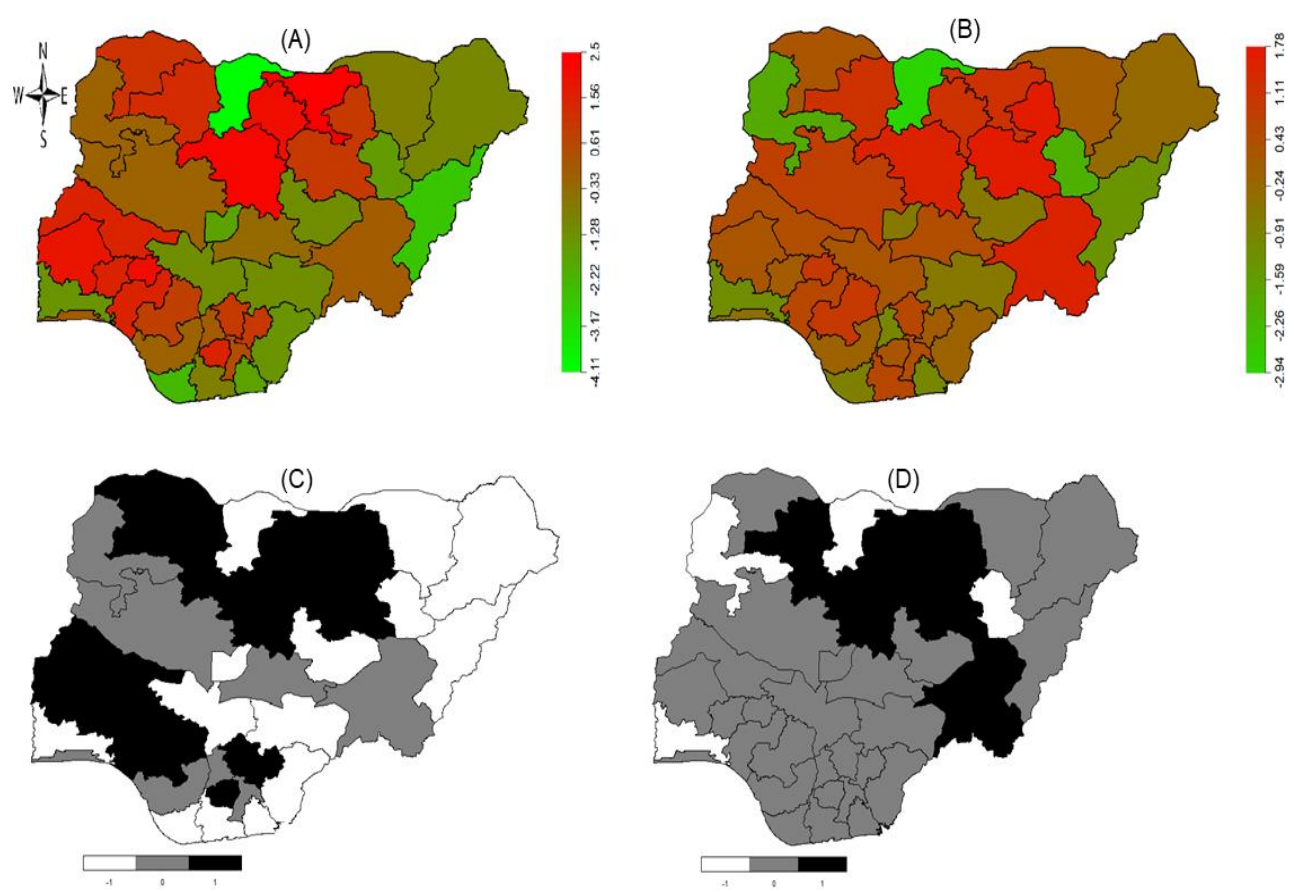

Non-linear effects of girl's and mother's ages, for the unadjusted and fully adjusted models, are shown in figures 13 and 14, respectively. Figure 13 shows that the likelihood of a girl being cut increased with age (right), while the likelihood being cut decreased if her mother was younger than 25 (right), with no significant influence if a mother was age 25 and older (Figure 13, left).

Figure 13. Non-linear effects of girl's (left) and mother's (right) age, 2013 DHS unadjusted model (Model I)
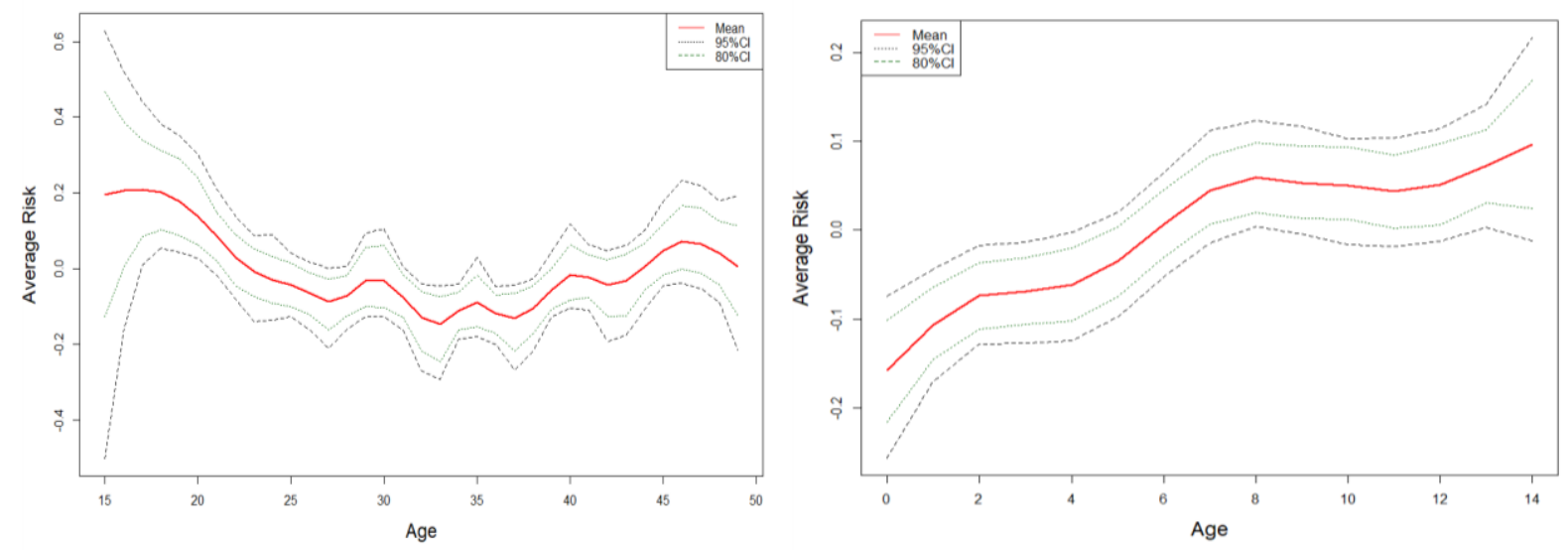

The non-linear effects of girl's and mother's age from the fully adjusted model (III) show that the likelihood of a girl being cut increased with her age, but decreased as her mother became older, a rather unexpected result that contradicts other surveys in which younger women are less likely to cut their daughters. 
Figure 14. Non-linear effects of girl's (left) and mother's (right) age, 2013 DHS unadjusted model (Model III)
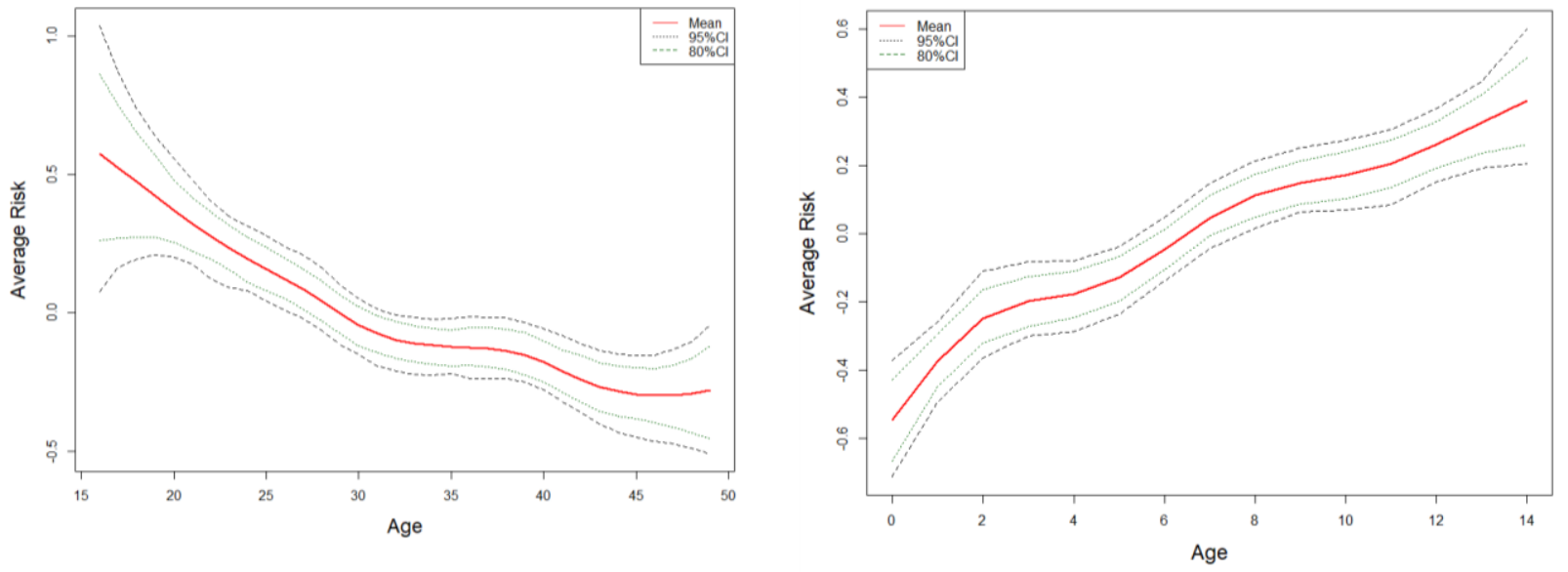

\section{6-17 Multiple Indicator Cluster Survey (MICS)}

The Bayesian geo-additive hierarchical multivariate regression analyses results, after multiple adjustments of factors that could confound the relationship between a girl's FGM/C likelihood and her mother's circumstances, including their place of residence (state), are presented in Table A6 (Appendix). Only results from Model III are presented. In 2016-17, living in the North West increased a girl's likelihood of being cut. A Fulani or Yoruba girl was more likely to be cut than a girl from other ethnic backgrounds. Compared to women with higher education, likelihood of FGM/C was greater for daughters whose mothers had no education, but also greater when the mother had secondary education.

A girl's likelihood of having undergone FGM/C was higher if her mother had been cut, or if her mother supported FGM/C's continuation, or if her mother believed FGM/C is a religious requirement. The likelihood of a girl being cut was higher if her mother justified wife-beating for incidents such as burning food. A girl's likelihood of having undergone FGM/C was lower if her mother had never been married, or if her mother was the same age or younger than her husband or partner.

Figure 15 (following page) shows the estimated unobserved total spatial effects on FGM/C within states in 2016-17 for (A) the unadjusted spatial effect model and (B) fully adjusted model (Model III) with corresponding 95 percent posterior probability maps (C) and (D), respectively. The unadjusted maps ( $A$ and $C$ ) show significantly higher spatial effects on FGM/C prevalence in both the north and the south, depicting clearer state variability. Significant effects of unobserved location-specific factors on the likelihood of girls' FGM/C were found in six northern states-Zamfara, Kaduna, Kano, Jigawa, Plateau, and Kwara. Significantly high latent unadjusted location-specific effects were found in the southern states of Ondo, Oyo, Osun, Ekiti, and Imo. After adjusting for other potential confounders, significant unobserved geographic-specific factors were only noted for Taraba, Jigawa, and Plateau states. 
Figure 15. (A) Unadjusted spatial effect, (B) fully adjusted spatial effect, (C) $95 \%$ posterior probability for unadjusted spatial effect, (D) $95 \%$ posterior probability for fully observed spatial effect, 2016-17 MICS
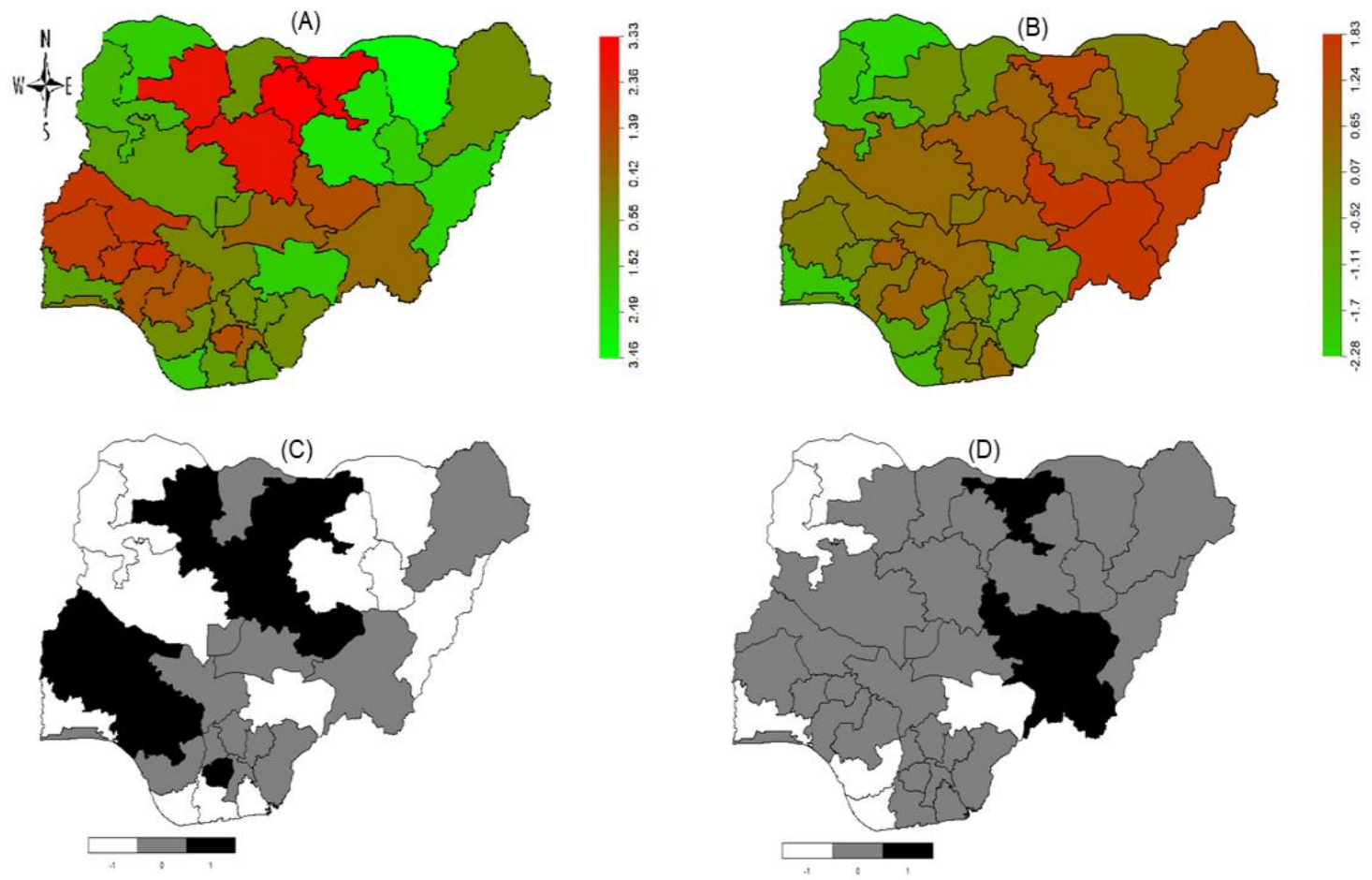

Mother's age was modelled as a non-linear continuous effect. Figure 16 shows estimated non-linear effects with the 80 percent and 95 percent credible regions. Unlike previous surveys, mother's age was not significantly associated with girls' FGM/C status, in both unadjusted and fully adjusted models.

Figure 16. Estimated non-linear effects of mother's age on the prevalence of FGM/C among Nigeria girls ages 14 and younger, from Nigeria MICS 2016-17
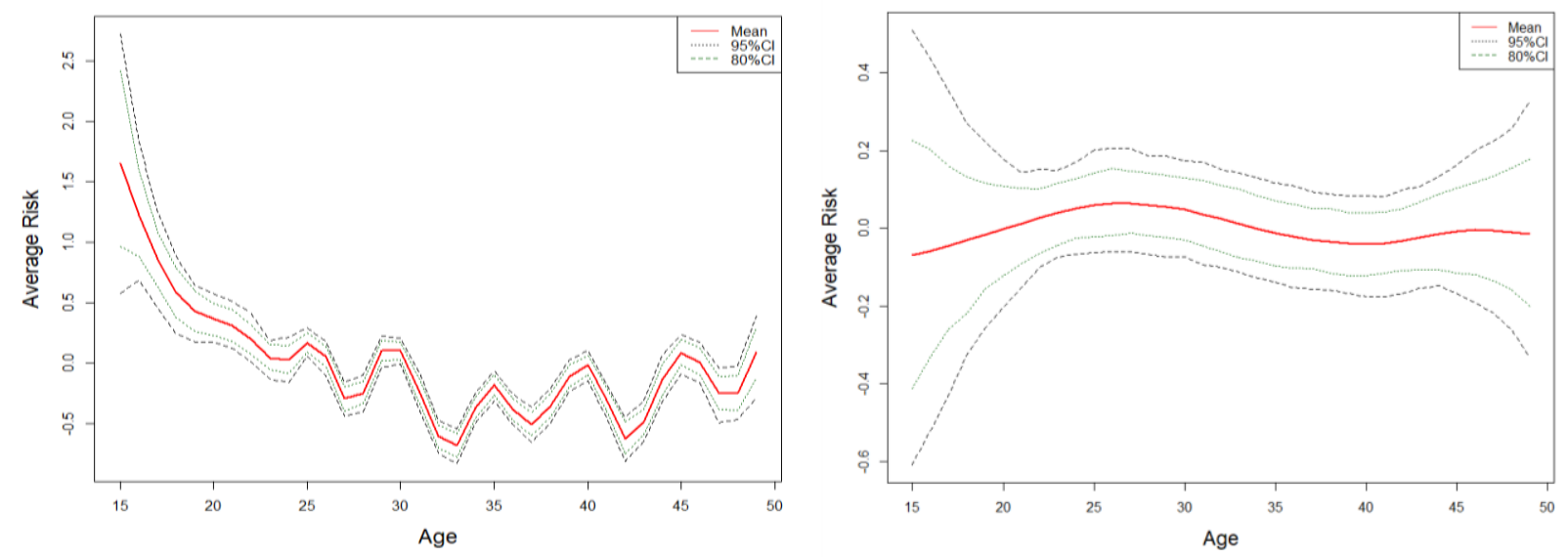


\section{3 to 2016-17 Combined Data}

DHS and MICS data from 2003 to 2016-17 were combined to examine changes over time. Table A7 (Appendix) presents the Bayesian geo-additive logistic regression analyses results, with Model I presenting unadjusted POR and Model II showing the fully adjusted POR (left panel). In the combined dataset, girls from households in the two richest wealth quintiles have a lower likelihood of being cut than girls from households in the middle wealth quintile. Compared with girls in North Central, girls who live in North West or South West have a higher likelihood of being cut. A girl's likelihood of having been cut is higher if she lives in rural area compared to an urban area. Daughters of women with no education have a higher likelihood of being cut than daughters of better educated mothers. Daughters of currently married women are more likely to be cut than daughters of women who have never married. Measures of women's agency, opportunities, and gender norms were significant predictors of their daughters' likelihoods of being cut. Girls whose mothers are younger or the same age as their husband or partner have a lower likelihood of being cut than girls whose mothers are older than their husband or partner. Daughters of cut women are more likely to be cut than daughters of uncut women.

Figure 17 shows the pooled total spatial effects maps for the fully adjusted model (A) and its corresponding 95 percent posterior probability map (B). Intensity of risk increases from pale green to pale red; in the 95 percent posterior probability map, black represents states where the likelihood of girls being cut is significantly high, and white represents significantly low risk states; grey represents non-significant risk states. The fully adjusted model, using the pooled dataset, shows unobserved geographic-specific effects for Edo, Ekiti, Kwara, Niger, Kano, Jigawa, and Bauchi states, with highest risks in Kano and Edo states.

Figure 17. (A) Fully adjusted model (Model III) and its $95 \%$ posterior probability (B), pooled 20032016-17 data
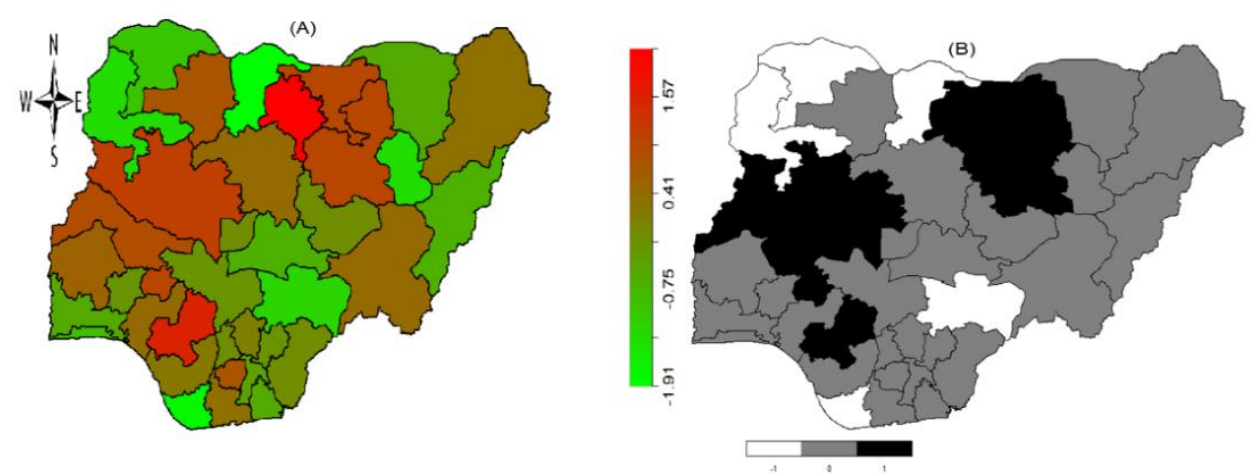

Figure 18 shows the non-linear effects of mother's age on likelihood of her daughter's FGM/C status (left panel) and the time trend for the pooled 2003 to 2016-17 data (right panel). Likelihood of FGM/C increases for girls whose mothers are ages 35 and older (left panel). Over time, a girl's likelihood of FGM/C decreases. 
Figure 18. Non-linear effects of mother's age (left) and temporal trend (right) from pooled 2003 to 2016-17 data
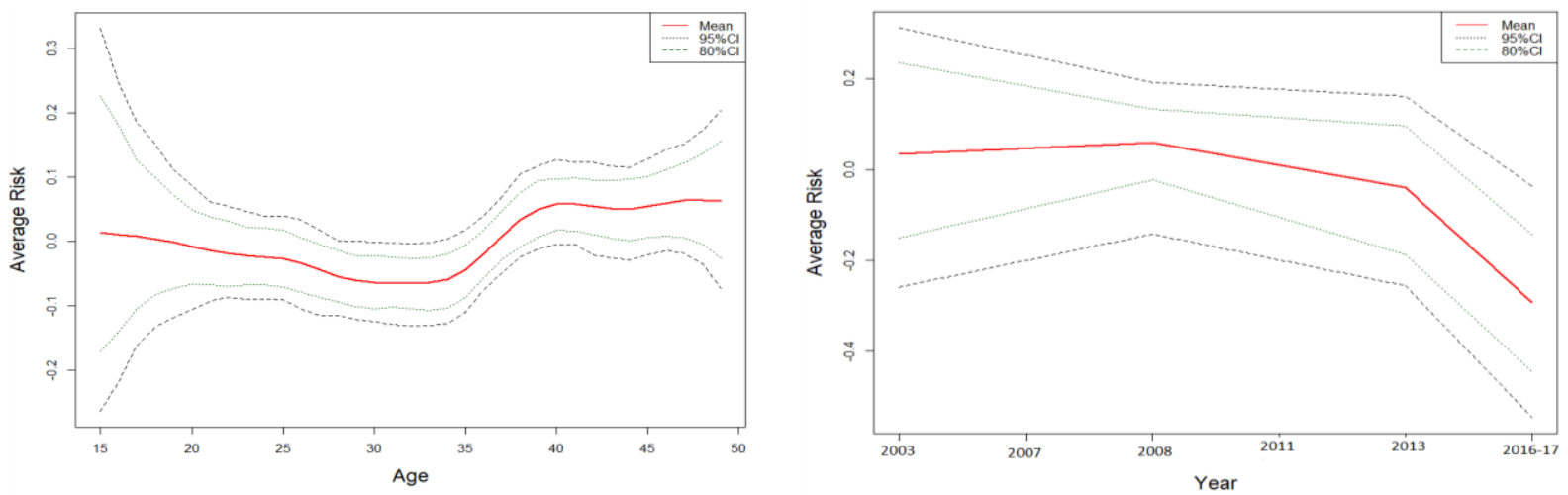

\section{Age at cutting: Descriptive survival analysis of girls' FGM/C status in 2013}

In the 2013 DHS, 13,933 women who had at least one living daughter reported a total of 5,128 cut girls, with median and inter-quartile range (IQR) survival time of two years (1 year to 4 years) -in other words, 50 percent of all cut girls were cut at the age of two. Table 2 lists the median survival time and $I Q R$, in years, for the predictors of FGM/C among girls.

The median survival time to cutting is similar for girls in urban and rural areas, consistent with the result of the Kaplan-Meier (KM) survival curve in Figure 19. Median survival time to cutting is longer for girls (3 years) whose mothers practice religions other than Christianity or Islam, for which the associated median survival time is two years. Median survival time is longest for Hausa girls (5 years), followed by Fulani girls ( 3 years). Median survival time is shortest for Yoruba girls ( 2 years). Median survival time is longest in the North East region (4 years).

Table 2. Median time to cutting (years) among girls in Nigeria (DHS 2013)

\begin{tabular}{|c|c|c|c|}
\hline Predictors & Level & Median & IQR \\
\hline \multirow[t]{2}{*}{ Residence } & Rural & 2 years & $(1,3)$ \\
\hline & Urban & 2 & $(1,5)$ \\
\hline \multirow[t]{4}{*}{ Education } & No education & 2 & $(1,5)$ \\
\hline & Primary & 2 & $(1,5)$ \\
\hline & Secondary & 2 & $(1,4)$ \\
\hline & Higher education & 2 & $(1,3)$ \\
\hline \multirow[t]{3}{*}{ Religion } & Christian & 2 & $(1,5)$ \\
\hline & Muslim & 2 & $(1,4)$ \\
\hline & Other & 3 & $(1,5)$ \\
\hline Ethnicity & Fulani & 3 & $(1,5)$ \\
\hline
\end{tabular}




\begin{tabular}{|c|c|c|c|}
\hline \multirow[t]{2}{*}{ Predictors } & \multirow{2}{*}{$\begin{array}{l}\text { Level } \\
\text { Hausa }\end{array}$} & \multirow{2}{*}{$\begin{array}{c}\text { Median } \\
5\end{array}$} & \multirow{2}{*}{$\begin{array}{c}\text { IQR } \\
(2,10)\end{array}$} \\
\hline & & & \\
\hline & Igbo & 2 & $(1,5)$ \\
\hline & Kanuri & - & - \\
\hline & Tiv & - & - \\
\hline & Yoruba & 2 & $(1,3)$ \\
\hline & Other & 2 & $(1,5)$ \\
\hline \multirow[t]{5}{*}{ Wealth index } & Poorest & 2 & $(1,3)$ \\
\hline & Poor & 4 & $(2,6)$ \\
\hline & Middle & 1 & $(1,5)$ \\
\hline & Richer & 2 & $(1,3)$ \\
\hline & Richest & 2 & $(1,3)$ \\
\hline \multirow[t]{6}{*}{ Region } & North Central & 2 & $(1,3)$ \\
\hline & North East & 4 & $(2,10)$ \\
\hline & North West & 3 & $(2,8)$ \\
\hline & South East & 2 & $(1,5)$ \\
\hline & South South & 1 & $(1,5)$ \\
\hline & South West & 2 & $(1,4)$ \\
\hline \multirow[t]{3}{*}{ Mother's FGM/C support } & Pro-FGM & 2 & $(1,4)$ \\
\hline & Anti-FGM & 2 & $(1,4)$ \\
\hline & Depends & 2 & $(2,4)$ \\
\hline \multirow[t]{2}{*}{ Mother's FGM/C status } & Cut & 3 & $(1,6)$ \\
\hline & Not cut & 2 & $(1,4)$ \\
\hline
\end{tabular}

The Kaplan-Meier estimator of the survivor functions of time to undergoing FGM/C by key socioeconomic factors associated with $\mathrm{FGM} / \mathrm{C}$-residence, region, religion, ethnicity, mother's education, household wealth, type of cutting-are plotted in Figures 19 to 25. Figure 19 shows that likelihood of FGM/C is similar in rural and urban areas until age one. After age one, FGM/C occurs 
earlier in urban areas (log rank test, $\mathrm{P}<0.001) . \mathrm{FGM} / \mathrm{C}$ seems to continue at the same rate in rural and urban areas among older age groups (around 10 years), until age 14.

Figure 19. Kaplan-Meier survival curves of timing of a girl's FGM/C, by place of residence, DHS 2013

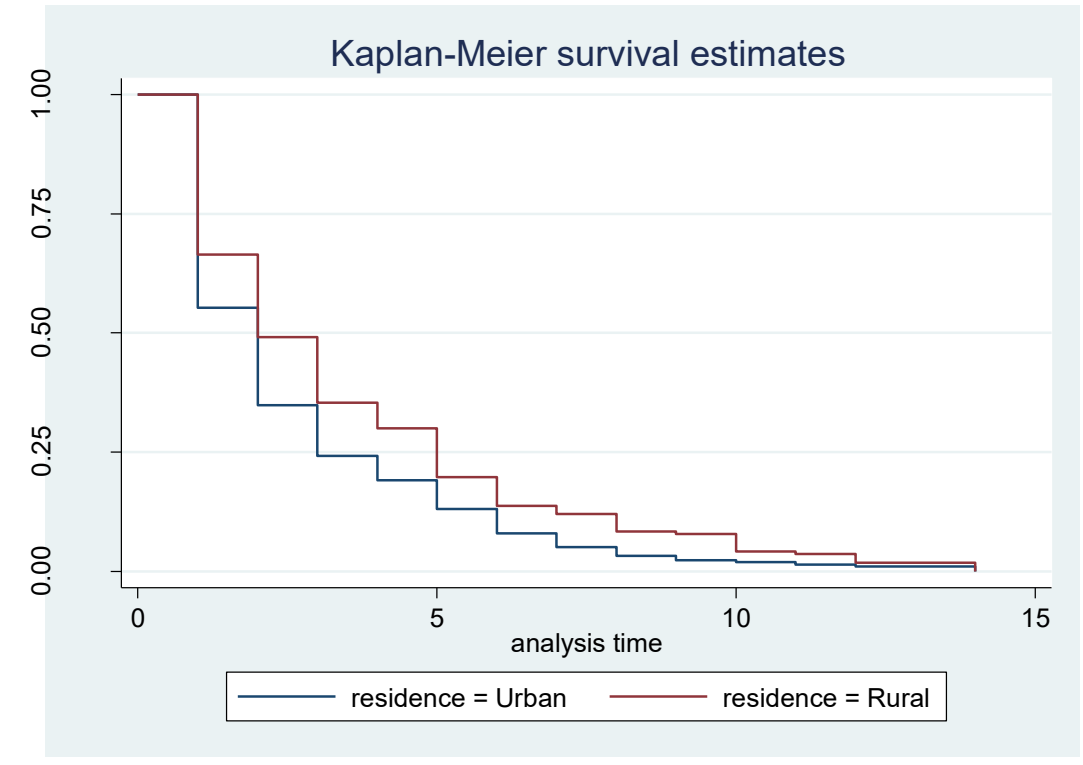

The pattern of cutting differs remarkably by region of residence (Figure 20) with the practice occurring much earlier in the North Central region, followed by South West (log rank test, $P<0.001)$. In both regions, cutting rarely occurred after age 10 .

Figure 20. Kaplan-Meier survival curves of timing of a girl's FGM/C, by region of residence, DHS 2013

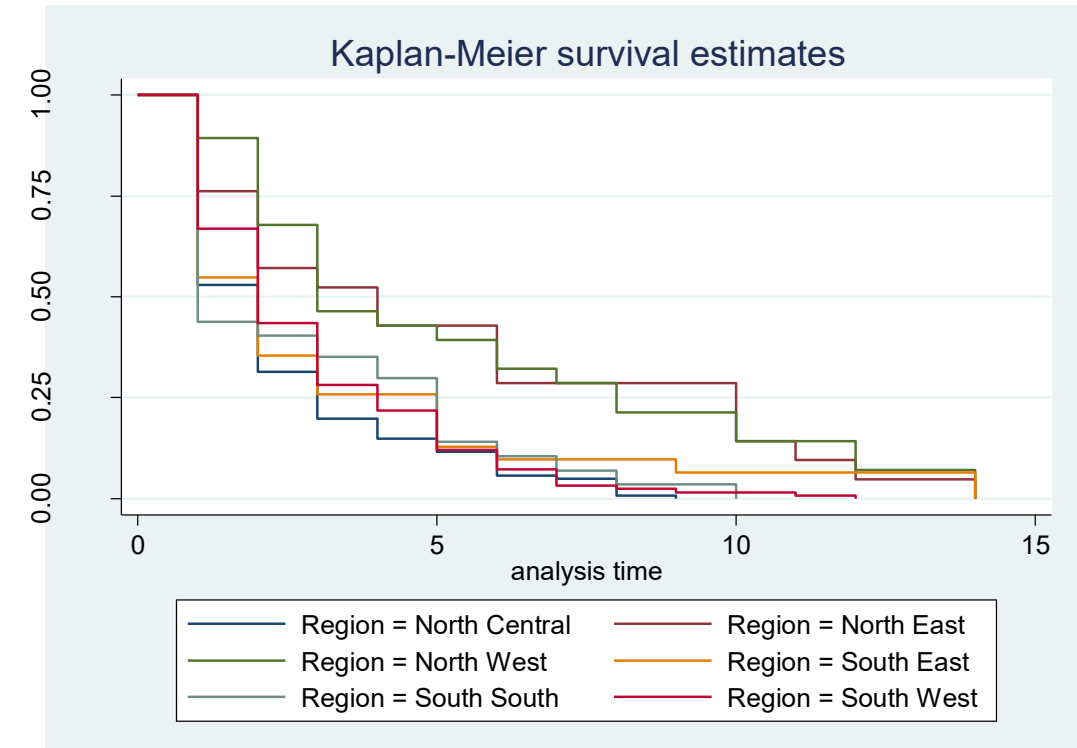


FGM/C occurred prior to the age of one among most girls, regardless of mother's education (Figure 21). More educated mothers, however, had their daughters cut much earlier (before the age of 6 ) than those with less education (log rank test, $\mathrm{P}<0.05$ ).

Figure 21. Kaplan-Meier survival curves of timing of a girl's FGM/C in relation to her mother's education, DHS 2013

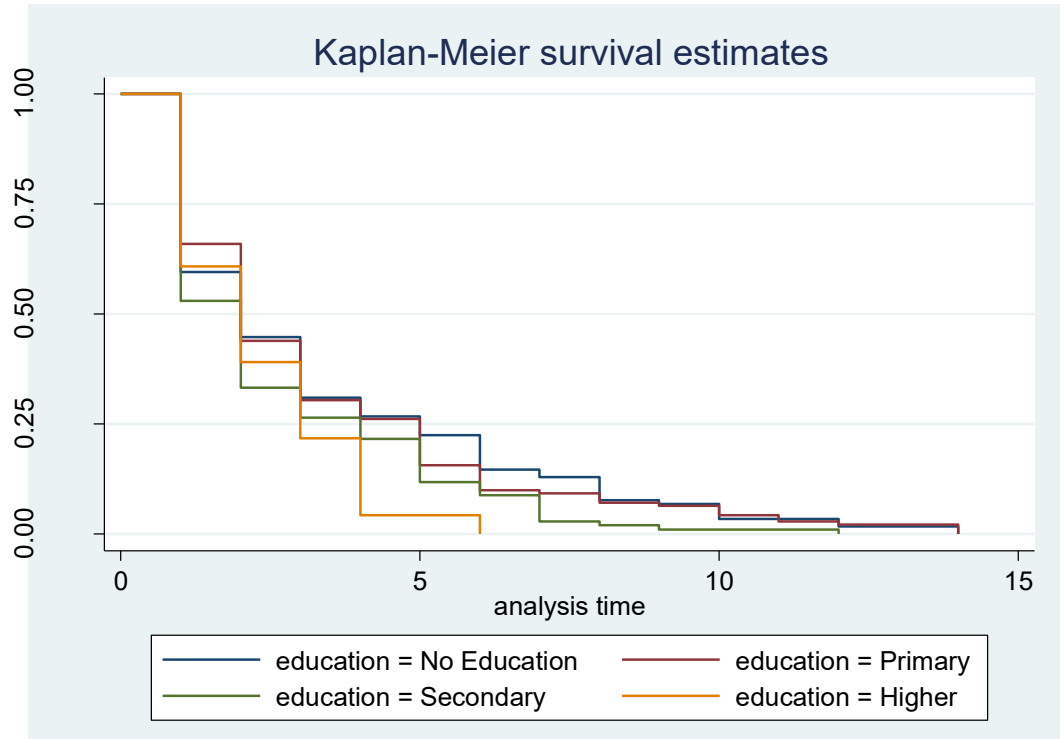

In terms of religion, FGM/C occurs much earlier among Muslim girls, before age five. Rates are indistinguishable after age five for all religious groups considered (log rank test, $\mathrm{P}=0.34$ ).

Figure 22. Kaplan-Meier survival curves of timing of a girl's FGM/C, by religion, DHS 2013

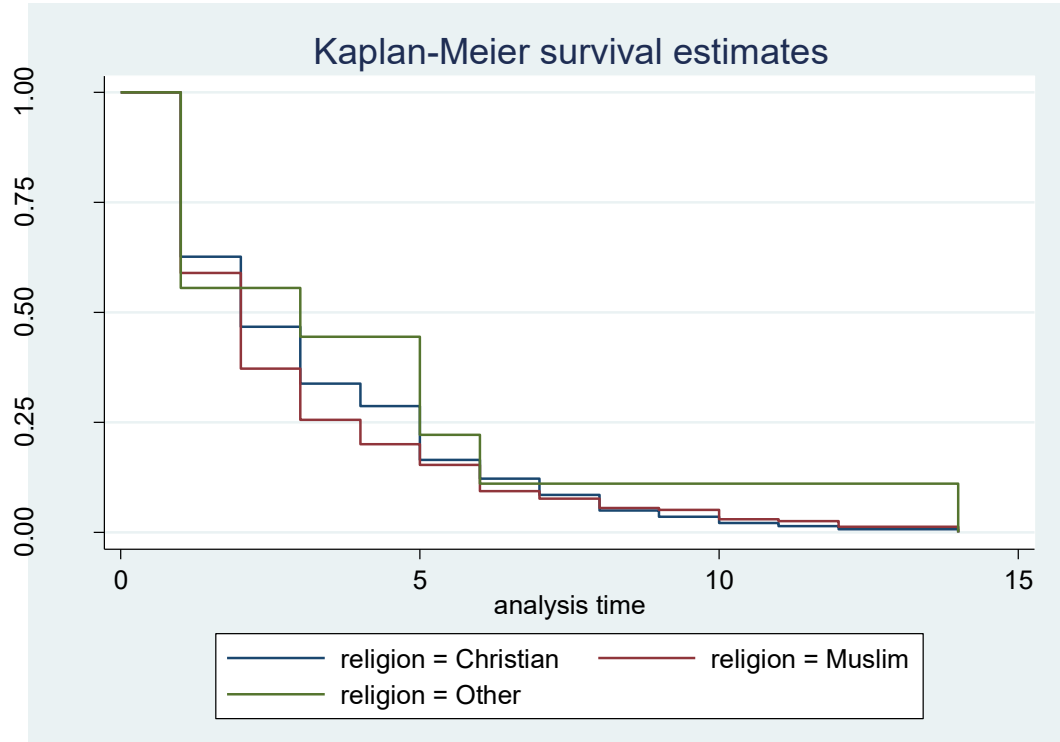


As shown in Figure 23, FGM/C occurred earlier among Yoruba girls than among girls of other ethnicities such as the Hausa (log rank test, $\mathrm{P}<0.001$ ). Among minority ethnic groups, such as Kanuri and Tiv with low prevalence of FGM/C, cutting occurred before age three.

Figure 23. Kaplan-Meier survival curves of timing of a girl's FGM/C, by ethnicity, DHS 2013

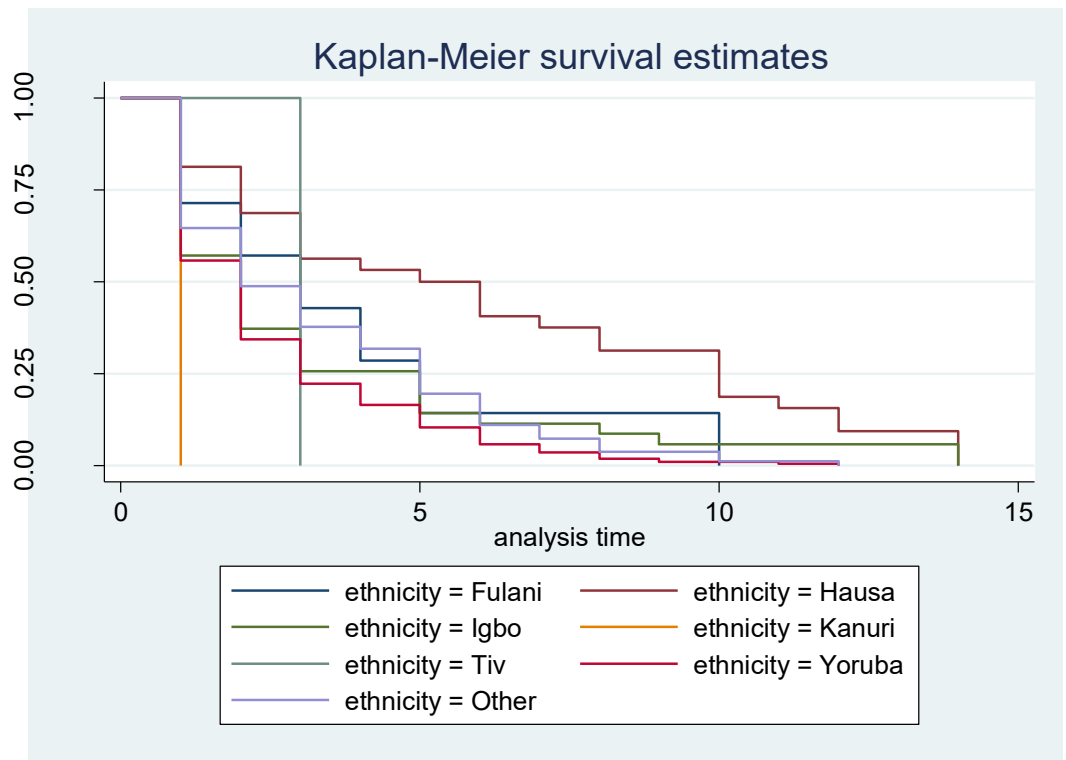

Figure 24 shows that daughters of women who would want FGM/C to continue were cut earlier than girls whose mothers were either ambivalent or did not support FGM/C' continuation.

Figure 24. Kaplan-Meier survival curves of timing of a girl's FGM/C in relation to her mother's support for FGM/C, DHS 2013

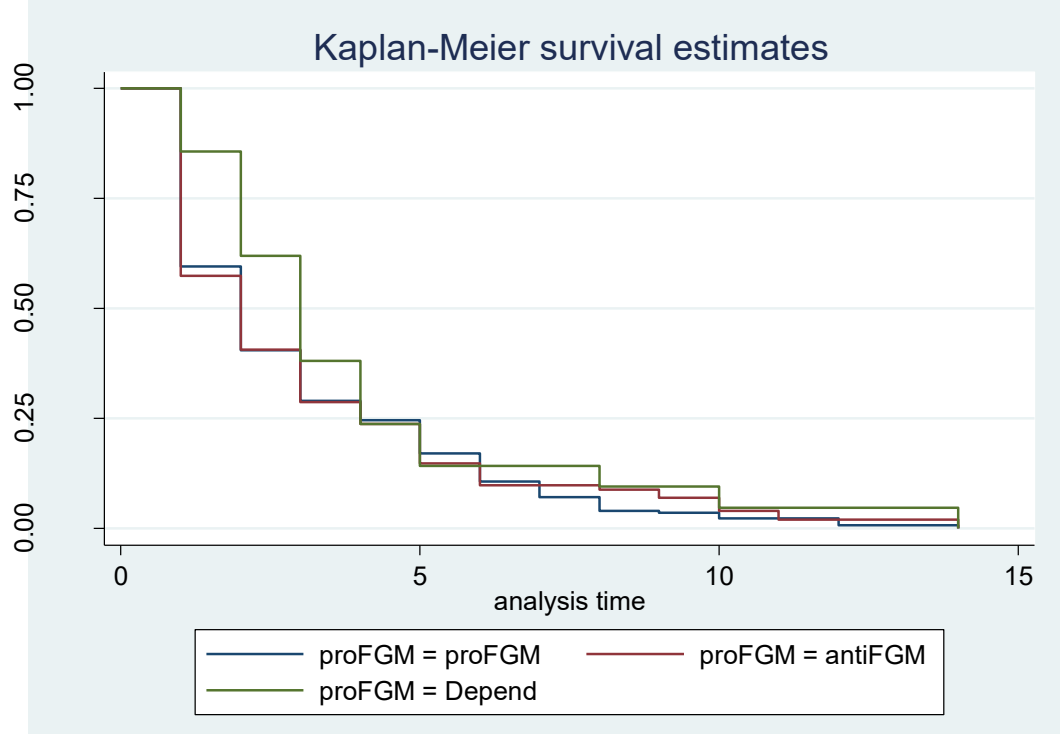


Figure 25 shows that daughters of cut women were cut at a much earlier age than daughters of uncut women.

Figure 25. Kaplan-Meier survival curves of timing of a girl's FGM/C in relation to her mother's FGM/C status, DHS 2013

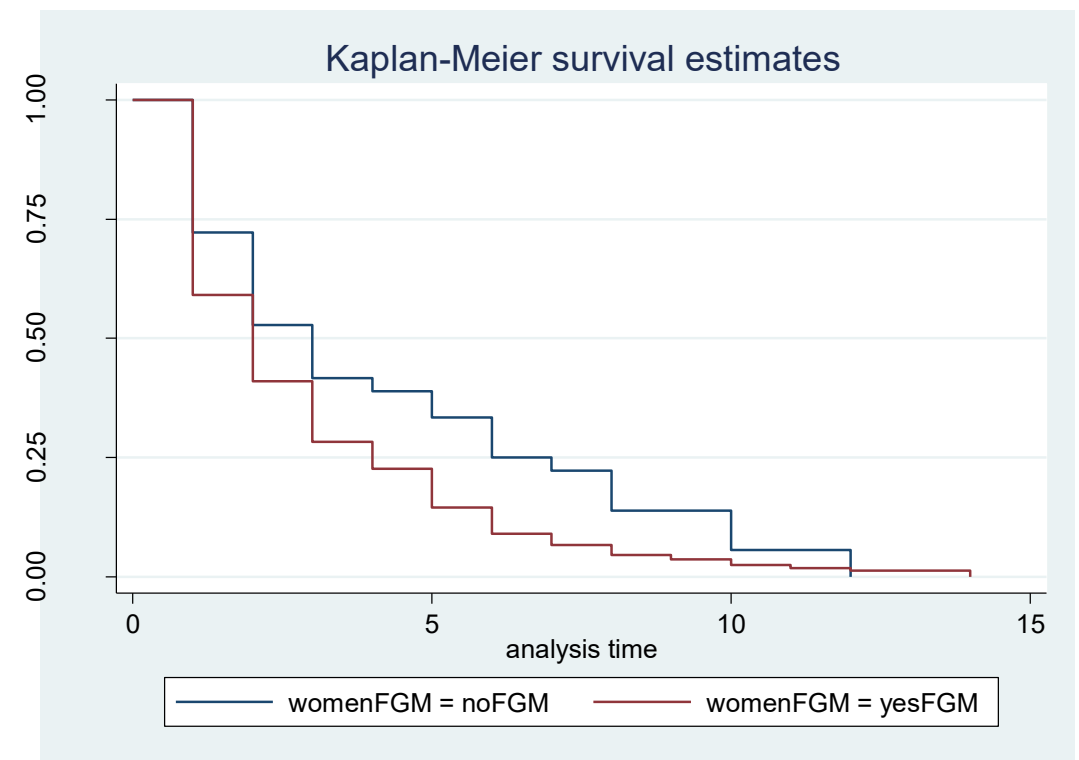

\section{Discussion}

This study employed advanced statistical techniques to investigate individual and community factors associated with FGM/C among girls ages 14 and younger in Nigeria. Bayesian hierarchical mixed models, which simultaneously controlled for the unobserved effects of geographical location as well as other linear and non-linear covariates, assessed the combined roles of these factors. Overall, these results indicate that FGM/C prevalence has declined in the south of Nigeria but has increased in the north.

These results align with several theories advanced in the FGM/C literature. The feminist theory suggests that $\mathrm{FGM} / \mathrm{C}$ persists because women are denied autonomy within patriarchal structures and are economically dependent (Gruenbaum 2011). After statistically controlling for household wealth and other covariates, a girl was found more likely to be cut if her mother had an informal job, or none at all, or if the mother was older than her husband, or if the mother did not have sole decision power about spending her own money or making large household purchases. These findings have been reported previously and suggest that $\mathrm{FGM} / \mathrm{C}$ abandonment policies and interventions addressing gender inequality are warranted within such social contexts in Nigeria (Abusharaf 2000, Hayford 2005, Yount 2002).

Similarly, FGM/C prevalence among girls is strongly correlated with mothers' beliefs and attitudes, which may be influenced by social norms factors. For example, daughters of mothers who believe FGM/C will enhance a girl's marriage market value are more likely to be cut than daughters of women who do not believe FGM/C enhanced a girl's marriageability. This finding supports the social norms theory positing that FGM/C persists within a context of competition for marriage, especially in a high social stratum where FGM/C is a marriage pre-requisite. Those who do not conform to the dictates of social rules risk not being married (Mackie 1996). 
Religion is also significantly associated with FGM/C. Apart from the results of the 2003 MICS, with its unadjusted model showing that girls with Christian mothers more likely to be cut than Muslim counterparts, findings in subsequent surveys show that daughters of Muslim women are more likely to be cut than daughters of Christian women. Although there is no known religious prescription of $\mathrm{FGM} / \mathrm{C}$ as a religious obligation, as reported in other studies, these results suggest that families of Muslim faith may practice FGM/C to conform with religious norms (Powell and Yussuf 2018, Kimani and Kabiru 2018). A religious basis for cutting may also explain the timing of cutting. This analysis revealed that 75 percent of cut Hausa girls (who are predominantly Muslim) were cut at the age of 10, while 75 percent of cut Yoruba girls were cut at the age of three: Cutting girls at an older age, when they are expected to participate in prayers, may explain this difference in cutting. For example, one study on FGM/C study among Somalis (predominantly Muslim) found that one reason for cutting girls is to make them pure and ready for prayers (Powell and Yussuf 2018).

These findings also align with the modernisation theory, which argues for the possibility of reducing demand for $\mathrm{FGM} / \mathrm{C}$ with high educational attainment for girls and women, utilising media to convey anti-FGM/C messages, encouraging non-agricultural opportunities (Boye 2002, Cloward 2016), and focusing on individual rights and opportunities rather than simply on collective rights (Hayford 2005). In all survey years, as well as the pooled data, girls whose mothers had lower levels of education were more likely to have undergone FGM/C than daughters of mothers with greater education. Girls whose mothers never read newspapers or magazines and who never watched television were more likely to have been cut than counterparts whose mothers were exposed to these media. These results suggest that it is important to invest in education, as it empowers women and enables them to better face challenges in the future. Educating girls to prepare them for employment opportunities beyond the traditional sector of agriculture (Cloward 2016) may further contribute to declines in FGM/C practice. However, the "educational fallacy," formulated by Gerry Mackie (1996), warns, however, of the unfounded belief that the education of women will automatically lead to their resistance or refutation of $F G M / C$. Other contextual issues must be considered, including the practise of $F G M / C$ as a social norm, which may drive the practice even in settings characterized by high levels of education. For example, the Yoruba are among the most educated ethnic groups in Nigeria and yet they exhibit higher FGM/C prevalence.

The methodology used in this analysis allowed us to assess whether normative influences as well as women's support for FGM/C are key to its continuation in Nigeria and revealed areas where the practice is prevalent ("hotspots") with associated risk factors. In Senegal, Burkina Faso, and Egypt, Farina and Ortensi (2014) found that FGM/C prevalence among daughters was higher for those whose mothers were cut. A study in Kenya (Achia 2014) found that a woman's FGM/C status was a key determinant of her support for the continuation of the practice. However, these comparisons must be interpreted with caution as the studies mentioned above were conducted in different contexts. FGM/C is often viewed as a requirement that prepares a girl for marriage, inhibits urge for premarital sex, and promotes marital fidelity. Under these contexts, it is very difficult for total abandonment to be achieved independently by individuals as an uncut girl risks being socially sanctioned including exclusion from the marriage market (Mackie 2000, Mackie and Lejeune 2009, Shell-Duncan et al. 2011).

Regional shifts in FGM/C prevalence in Nigeria are noteworthy, as most intervention programmes have focused on high prevalence states in the south, with more emphasis on educating the general public (Kandala et al. 2009). The north of Nigeria may therefore not have experienced the same FGM/C declines as the south because interventions have largely been focused on hotspots, which were thought to be only in the south based on available data.

Regional variances in FGM/C prevalence may also result from differences in the adoption of antiFGM/C laws. Although Nigeria enacted its 2015 Violence Against Persons Act (Prohibition Act), which criminalises FGM/C in Nigeria, some Nigerian communities have continued FGM/C practice unabated. 
As a federal law the act only took effect automatically in FCT, with states either required to adopt the law or create their own anti-FGM/C laws. Some states had their own anti-FGM/C laws prior to the passing of the VAPP Act. However, not all states have these laws in place.

The observed higher prevalence of FGM/C in northern Nigeria since 2008 does not necessarily mean the practice has been recently adopted there. It is possible that FGM/C data in the country's north have been better collected in more recent surveys, and only now a more accurate representation, but not necessarily a new manifestation, has come from the north.

Finally, our approach allowed us to identify geographical locations (states), with significantly high unobserved geographical location effects. These results suggest the need for context-specific research and interventions in states like Ekiti, Kwara, Niger, Kano, Jigawa, and Bauchi.

\section{Limitations and strengths}

This report has several shortcomings. Reliance on cross-sectional DHS and MICS means that causation between individual and community factors and FGM/C cannot be implied. Second, the data used are derived from mothers' self-reported data, and precise rates of prevalence may well be underreported. Further, there is a strong possibility that girls uncut at the time of the survey were still at risk of being cut in the future. The survival analysis techniques used here addressed this issue by allowing for data censoring. Despite these shortfalls, this report is a robust analysis based on large, nationally representative data that provides key insights into the possible effects of individual and community factors on a girl's likelihood of undergoing FGM/C in Nigeria.

\section{Conclusion}

The roles of individual-level and community-level factors in explaining the increased prevalence of FGM/C were investigated in the context of Nigeria. Social norm factors, poverty, low levels of education, gender inequality, and rural residence were among the key drivers of the observed prevalence among girls ages 14 and younger. The advanced statistical methods employed in this study identified areas ("hotspots") where observed FGM/C prevalence is largely driven by unobserved, local factors. These results point to the need for further investigation to understand and address these unobserved factors.

Overall, FGM/C prevalence has declined over the years in the South but there has been a shift to the North. This shows that the fight against the practice of FGM/C in Nigeria is not yet over and calls for targeted programmatic interventions that seek to empower women and encourage changes that would achieve stable FGM/C abandonment in Nigeria. Finally, the report provides concrete context-specific evidence to assist policymakers and those implementing FGM/C abandonment programmes to identify hotspots of FGM/C and the associated factors in order to intervene successfully. Such interventions must involve governments at all levels, politicians, community and religious leaders in order to ensure total and enduring abandonment of the practice.

\section{Research and Programmatic Implications}

\section{Research Implications}

Further research is needed to understand unobserved, geographic factors within identified hotspots and to develop suitable approaches to address them.

Comparative cross-country analysis is needed to determine how the observed influence of individual and community factors compare across countries, to identify practicable approaches that can be increased in scale and effectively promote abandonment of the practice 


\section{Programmatic Implications}

These findings underscore the need for FGM/C abandonment policies and interventions that address gender inequalities and promote women's economic empowerment and increase access to education. Interventions containing religious and culturally sensitive elements should be prioritised especially in the northern part of the country where FGM/C is being observed. 


\section{References}

Abdelshahid, A. and C. Campbell. 2015. 'Should I circumcise my daughter?' Exploring diversity and ambivalence in Egyptian parents' social representations of female circumcision. Journal of Community and Applied Social Psychology 25: 49-65.

Achia, T. 2014. Spatially modelling and mapping of female genital mutilation in Kenya. BMC public health 14: 276.

Abdulcadir, J., M.I. Rodriguez, L. Say. 2015. Research gaps in the care of women with female genital mutilation: an analysis. BJOG 122: 294-303.

Abusharaf, R.M. 2000. Revisiting feminist discourses on infibulation: Responses from Sudanese feminists. In Female "Circumcision" in Africa: Culture, Controversy, and Change, Shell-Duncan, B.; Hernlund, Y., Eds. Lynne Rienner Publishers: Boulder, CO. 151-166.

Amemiya, T. 1981. Qualitative Response Models: A survey. Journal of Economic Literature 19(4): 1483-1536.

Umlauf, N., D. Adler, T. Kneib. 2015. Structured Additive Regression Models: An R Interface to BayesX. Journal of Statistical Software 63(21).

Boyle, E.H. 2002. Female Genital Cutting: Cultural Conflict in the Global Community. Johns Hopkins University Press: Baltimore.

Cislaghi, B. and L. Heise. 2018. Using social norms theory for health promotion in low-income countries. Health Promotion International. doi: 10.1093/heapro/day017.

Farina, P. and L.E. Ortensi. 2014. Mother to daughter transmission of Female Genital Cutting in Egypt, Burkina Faso and Senegal. African Population Studies 28(2).

Fahrmeir, L. and S. Lang. 2001. Bayesian inference for generalized additive mixed models based on Markov random field priors. Applied Statistics 50: 201-220.

Gruenbaum, E. 2001. The Female Circumcision Controversy: An Anthropological Perspective. University of Pennsylvania Press: Philadelphia.

Hayford, S. 2005. Conformity and change: Community effects on female genital cutting in Kenya. Journal of Health and Social Behavior 46(2): 121-140.

Hayford, S. and J. Trinitapoli. 2011. Religious differences in female genital cutting: A case study from Burkina Faso. Journal for the Scientific Study of Religion 50(2): 252-271.

Kandala, N.B., N. Nwakeze, S. Ngianga, I.I. Kandala. 2009. Spatial distribution of female genital mutilation in Nigeria. American Journal of Tropical Medicine and Hygiene 81(5): 784-792.

Kimani, S. and C.W. Kabiru. 2018. Shifts in Female Genital Mutilation/Cutting in Kenya: Perspectives of Families and Health Care Providers. Evidence to End FGM/C: Research to Help Girls and Women Thrive. New York: Population Council.

Mackie, G. and J. LeJeune. 2009. Social Dynamics of Abandonment of Harmful Practices: A new look at the theory. Special Series on Social Norms and Harmful Practices, Innocenti Working Paper 6.

Mackie, G. 1996. Ending footbinding and infibulation: A convention account. American Sociological Review 61: 999-1017.

Mackie, G. 2000. Female genital cutting: The beginning of the end. In Female "Circumcision" in Africa: Culture, Controversy, and Change, Shell-Duncan, B., Y. Hernlund eds. Lynne Rienner Publishers: Boulder, CO, 253-283. 
Mackie, G. and J. LeJeune. 2009. Social Dynamics of Abandonment of Harmful Practices: A New Look at the Theory; Innocenti Working Paper 2009-06. Florence: UNICEF Innocenti Research Centre.

Mackie, G., F. Moneti, H. Shakya, E. Denny. 2015. What are Social Norms? How are they Measured? New York: UNICEF. www.unicef.org/protection/files/4 0930 while what are Social Norms.pdf

Mediterranean Institute of Gender Studies. 2015. Repositioning FGM as a Gender and Development issue. www.medinstgenderstudies.org/wp-content/uploads/endFGM-PositionPaper-ENonline.pdf

Merry, S. E. 2006. Human Rights and Gender Violence. The University of Chicago Press: Chicago.

Modrek, S., J.X. Liu. 2013. Exploration of pathways related to the decline in female circumcision in Egypt. BMC Public Health 13: 921. www.biomedcentral.com/1471-2458/13/921.

National Bureau of Statistics [NBS] and United Nations Children's Fund [UNICEF]. 2008. Nigeria Multiple Indicator Cluster Survey 2007 Final Report. Abuja, Nigeria: NBS. www.nigerianstat.gov.ng/nada/index.php/catalog/25/download/208

NBS, UNICEF, United Nations Population Fund [UNFPA]. 2013. Nigeria Multiple Indicator Cluster Survey 2011. Abuja: NBS. www.unicef.org/nigeria/media/1376/file

NBS and UNICEF. 2017. Multiple Indicator Cluster Survey 2016-17, Survey Findings Report. Abuja: NBS and UNICEF. http://microdata.worldbank.org/index.php/catalog/3002/download/41925

National Population Commission [NPC] Nigeria and ORC Macro. 2004. Nigeria Demographic and Health Survey 2003. Calverton, Maryland: NPC Nigeria and ORC Macro. www.dhsprogram.com/pubs/pdf/FR148/FR148.pdf

NPC Nigeria and ICF Macro. 2009. Nigeria Demographic and Health Survey 2008. Abuja: NPC Nigeria and ICF Macro. www.dhsprogram.com/pubs/pdf/FR222/FR222.pdf

NPC Nigeria and ICF International. 2014. Nigeria Demographic and Health Survey 2013. Abuja: NPC Nigeria and ICF International. www.dhsprogram.com/pubs/pdf/FR293/FR293.pdf

Naussbaum, M. 1997. Capabilities and Human Rights. Fordham Law Review 66(2).

Population Council. 2006. Considerations on the use and interpretation of survey data on FGM/C. www.popcouncil.org/uploads/pdfs/2016RH FGMC-HouseholdSurveyTechBrief.pdf

Powell R.A. and M. Yussuf. 2018. Changes in FGM/C in Somaliland: Medical narrative driving shift in types of cutting. Evidence to End FGM/C: Research to Help Women Thrive. New York: Population Council.

Sen, A. 1993. "Capability and well-being", in M. Nussbaum and A. Sen (eds) The Quality of Life Oxford: Clarendon Press. www.wvi.org/fr/senegal/pressrelease/world-vision.com

Sen, A. 1980. Equality of What? The Tanner Lectures on Human Values 195, S.M. McMurrin ed.

Shell-Duncan, B., D. Gathara, Z. Moore. 2017. Female Genital Mutilation/Cutting in Kenya: Is Change Taking Place? Descriptive Statistics from Four Waves of Demographic and Health Surveys. Population Council: New York.

Shell-Duncan, B., A. Moreau, K. Wander, S. Smith. 2018. The role of older women in contesting norms associated with female genital mutilation/cutting: a factorial focus group analysis. PLOS ONE. https://doi.org/10.1371/journal.pone.0199217. 
Shell-Duncan, B., R. Naik, C. Feldman-Jacobs. 2016. A State-of-the-Art Synthesis on Female Genital Mutilation/Cutting: What Do We Know Now? New York: Population Council http://www.popcouncil.org/EvidencetoEndFGM-C.

Shell-Duncan, B., K. Wander, Y. Hernlund, A. Moreau. 2011. Dynamics of change in the practice of female genital cutting in Senegambia: Testing predictions of social convention theory. Social Science and Medicine 73: 1275-1283.

Shetty, P. 2014. Slow progress in ending female genital mutilation. Bulletin of the World Health Organization 92(1): 6-7. doi: 10.2471/BLT.14.020114.

UNFPA-UNICEF How to Transform a Social Norm. Reflections on Phase II of the UNFPA-UNICEF Joint Programme on Female Genital Mutilation; 2018.

UNICEF Dynamics of Social Change: Toward the Abandonment of Female Genital Mutilation/Cutting in Five African Countries; Innocenti Research Center: Florence, 2010.

UNICEF, Female Genital Mutilation/Cutting: A Global Concern. New York: UNICEF. 2016.

WHO Eliminating Female Genital Mutilation: An Interagency Statement. (WHO, UNFPA, UNICEF, UNIFEM, UNHCHR, UNHCR, UNECA, UNESCO, UNDP, UNAIDS); World Health Organization: Geneva, 2008.

Yount, K. 2002. Like mother, like daughter? Female genital cutting in Minia, Egypt. Journal of Health and Social Behavior 43: 336-358. 


\section{Appendix}

Table A1. Bayesian Geo-additive Multilevel Regression, 2003 DHS

\begin{tabular}{|c|c|c|c|c|}
\hline Predictor & Level & $\begin{array}{l}\text { Model I POR } \\
\quad(95 \% \mathrm{Cl})\end{array}$ & Model II POR (95\% Cl) & $\begin{array}{l}\text { Model III POR } \\
(95 \% \mathrm{Cl})\end{array}$ \\
\hline \multicolumn{5}{|c|}{ DEMOGRAPHIC } \\
\hline \multicolumn{5}{|c|}{ Place of residence } \\
\hline & Rural (ref) & & & \\
\hline & Urban & $1.13(0.95,1.34)$ & $1.18(0.92,1.5)$ & $1.81(1.34,2.65)$ \\
\hline \multicolumn{5}{|l|}{ Region } \\
\hline & North Central (ref) & & & \\
\hline & North East & $0.03(0.01,0.07)$ & $0.04(0.00,0.55)$ & $0.36(0.02,6.51)$ \\
\hline & North West & $0.09(0.04,0.15)$ & $0.12(0.02,0.82)$ & $0.58(0.04,7.98)$ \\
\hline & South East & $1.37(1.05,1.80)$ & $2.96(0.51,22.48)$ & $0.9(0.04,17.77)$ \\
\hline & South South & $0.84(0.63,1.13)$ & $1.88(0.29,13.00)$ & $1.69(0.05,19.87)$ \\
\hline & South West & $2.54(1.95,3.33)$ & $5.46(1.05,38.78)$ & $3.55(0.2,71.4)$ \\
\hline \multicolumn{5}{|c|}{ Wealth Index } \\
\hline & Middle (ref) & & & \\
\hline & Lowest & $1.09(0.81,1.40)$ & $1.24(0.87,1.74)$ & $1.46(0.83,2.5)$ \\
\hline & Second & $0.99(0.75,1.34)$ & $1.14(0.8,1.66)$ & $1.53(0.76,2.58)$ \\
\hline & Higher & $0.81(0.62,1.07)$ & $0.7(0.51,1.03)$ & $0.67(0.36,1.14)$ \\
\hline & Highest & $0.78(0.6,0.96)$ & $0.48(0.34,0.66)$ & $0.68(0.33,1.38)$ \\
\hline \multicolumn{5}{|l|}{ Religion } \\
\hline & Christian (ref) & & & \\
\hline & Muslim & $0.64(0.53,0.78)$ & $2.27(1.59,3.27)$ & $2.45(1.39,4.35)$ \\
\hline & Traditionalist/Other & $1.19(0.57,2.12)$ & $1.28(0.7,2.34)$ & $0.55(0.21,1.43)$ \\
\hline \multicolumn{5}{|c|}{ Marital status } \\
\hline
\end{tabular}




\begin{tabular}{|c|c|c|c|c|}
\hline Predictor & Level & $\begin{array}{l}\text { Model I POR } \\
(95 \% \mathrm{Cl})\end{array}$ & Model II POR (95\% Cl) & $\begin{array}{l}\text { Model III POR } \\
(95 \% \mathrm{Cl})\end{array}$ \\
\hline & $\begin{array}{l}\text { Currently married/in } \\
\text { union (ref) }\end{array}$ & & & \\
\hline & Never married & $0.59(0.25,1.28)$ & $0.43(0.17,0.99)$ & $0.08(0,3.52)$ \\
\hline & Formerly married & $0.72(0.46,1.1)$ & $0.68(0.41,1.09)$ & $0.05(0,0.91)$ \\
\hline \multicolumn{5}{|c|}{ Age difference with husband/partner (currently married women only) } \\
\hline & Wife is older (ref) & & & \\
\hline & Wife is same age & $0.31(0.04,1.55)$ & $0.15(0.01,1.09)$ & \\
\hline & $\begin{array}{l}\text { Wife is 1-4 years } \\
\text { younger }\end{array}$ & $1.35(0.49,3.46)$ & $1.05(0.38,3.02)$ & \\
\hline & $\begin{array}{l}\text { Wife is } 5-9 \text { years } \\
\text { younger }\end{array}$ & $1.08(0.41,2.93)$ & $0.85(0.32,2.43)$ & \\
\hline & $\begin{array}{l}\text { Wife is } 10+\text { years } \\
\text { younger }\end{array}$ & $1.11(0.41,2.8)$ & $0.92(0.33,2.51)$ & \\
\hline \multicolumn{5}{|l|}{ Ethnicity } \\
\hline & Fulani (ref) & & & \\
\hline & Hausa & $5.33(0.79,111.71)$ & $2.54(0.34,60.43)$ & $0.82(0.09,8.79)$ \\
\hline & Igbo & $\begin{array}{c}59.41(10.54 \\
1061.16)\end{array}$ & $4.38(0.63,122.16)$ & $2.36(0.16,25.91)$ \\
\hline & Kanuri & & & \\
\hline & Tiv & & & \\
\hline & Yoruba & $\begin{array}{c}159.34(26.72 \\
2737.88)\end{array}$ & $10.65(1.49,263.93)$ & $2.91(0.21,32.98)$ \\
\hline & Other & $21.81(3.68,355.58)$ & $1.68(0.22,45.04)$ & $0.92(0.06,8.75)$ \\
\hline \multicolumn{5}{|c|}{ SOCIAL NORMS \& BELIEFS } \\
\hline \multicolumn{5}{|c|}{ Women's attitudes toward FGM/C } \\
\hline \multicolumn{5}{|c|}{ Mother Cut } \\
\hline & No (ref) & & & \\
\hline
\end{tabular}




\begin{tabular}{|c|c|c|c|c|}
\hline Predictor & Level & $\begin{array}{c}\text { Model I POR } \\
(95 \% \mathrm{Cl})\end{array}$ & Model II POR (95\% Cl) & $\begin{array}{c}\text { Model III POR } \\
(95 \% \mathrm{Cl})\end{array}$ \\
\hline & Yes & $22.14(16,32.27)$ & $18(11.39,28.78)$ & $\begin{array}{c}19.7(11.74 \\
33.58)\end{array}$ \\
\hline \multicolumn{5}{|c|}{ Circumcision should continue or be stopped. } \\
\hline & Discontinued (ref) & & & \\
\hline & Continued & $5.28(3.40,7.60)$ & $5.01(3.07,8.35)$ & $7.24(4.07,13.17)$ \\
\hline & Depends & $4.82(2.74,9.16)$ & $2.77(1.46,5.10)$ & $2.80(1.28,7.78)$ \\
\hline & Don't know & $2.76(1.61,4.97)$ & $2.49(1.31,4.81)$ & $3.98(1.72,8.84)$ \\
\hline \multicolumn{5}{|c|}{ Circumcision is required by religion. } \\
\hline & No $(r e f)$ & & & \\
\hline & Yes & $0.99(0.72,1.35)$ & $1.2(0.85,1.65)$ & $1.26(0.82,2)$ \\
\hline & Don't know & $1.13(0.75,1.63)$ & $1.05(0.71,1.52)$ & $0.79(0.49,1.27)$ \\
\hline \multicolumn{5}{|c|}{ Mother believes men want FGM to continue } \\
\hline & Discontinued (ref) & & & \\
\hline & Continued & $1.52(1.01,2.25)$ & $1.37(0.84,2.28)$ & $1.43(0.76,2.64)$ \\
\hline & Depends & $0.43(0.23,0.79)$ & $0.53(0.24,1.17)$ & $0.41(0.14,1.11)$ \\
\hline & Don't know & $0.78(0.5,1.11)$ & $0.74(0.48,1.15)$ & $0.55(0.32,0.9)$ \\
\hline \multicolumn{5}{|c|}{ WOMEN'S AGENCY/ OPPORTUNITIES } \\
\hline \multicolumn{5}{|c|}{ Woman's education } \\
\hline & Higher (ref) & & & \\
\hline & No education & $2(1.31,3.05)$ & $4.41(2.71,7.52)$ & $10.4(3.68,31.91)$ \\
\hline & Primary & $2.02(1.28,3.05)$ & $2.34(1.53,3.78)$ & $2.74(0.98,7.15)$ \\
\hline & Secondary & $1.8(1.15,2.65)$ & $1.65(1.04,2.62)$ & $1.73(0.65,4.45)$ \\
\hline \multicolumn{5}{|c|}{ Husband's/partner's education (currently married women only) } \\
\hline & Higher (ref) & & & \\
\hline & No education & $2.31(1.57,3.38)$ & $2.83(1.71,4.78)$ & $0.73(0.35,1.48)$ \\
\hline
\end{tabular}




\begin{tabular}{|c|c|c|c|c|}
\hline Predictor & Level & $\begin{array}{c}\text { Model I POR } \\
(95 \% \mathrm{CI})\end{array}$ & Model II POR (95\% Cl) & $\begin{array}{c}\text { Model III POR } \\
(95 \% \mathrm{Cl})\end{array}$ \\
\hline & Primary & $2.86(1.99,4.27)$ & $2.55(1.58,4.15)$ & $1.53(0.78,3.07)$ \\
\hline & Secondary & $1.78(1.28,2.71)$ & $1.36(0.88,2.15)$ & $1.03(0.53,1.85)$ \\
\hline \multicolumn{5}{|c|}{ GENDER NORMS \& BASED VIOLENCE } \\
\hline \multirow{6}{*}{$\begin{array}{l}\text { Husband is justified } \\
\text { in hitting or beating } \\
\text { his wife if she: }\end{array}$} & No (ref) & & & \\
\hline & $\begin{array}{l}\text { Goes out without } \\
\text { telling him }\end{array}$ & $0.5(0.38,0.67)$ & $0.69(0.49,0.94)$ & $0.52(0.33,0.81)$ \\
\hline & Neglects children & $1.06(0.77,1.44)$ & $0.89(0.66,1.19)$ & $0.82(0.49,1.28)$ \\
\hline & Argues with him & $1.03(0.75,1.4)$ & $0.91(0.64,1.31)$ & $0.76(0.43,1.29)$ \\
\hline & $\begin{array}{l}\text { Refuses to have sex } \\
\text { with him }\end{array}$ & $0.63(0.46,0.85)$ & $1.15(0.81,1.61)$ & $0.99(0.61,1.69)$ \\
\hline & Burns the food & $1.2(0.86,1.62)$ & $2.02(1.46,2.87)$ & $2.57(1.47,4.53)$ \\
\hline \multicolumn{5}{|c|}{ Final say in making specific decisions: } \\
\hline \multicolumn{5}{|c|}{ Who makes decision on large household purchase } \\
\hline & Self (ref) & & & \\
\hline & $\begin{array}{l}\text { Jointly with } \\
\text { husband/someone } \\
\text { else }\end{array}$ & $1.31(0.89,1.88)$ & $0.8(0.52,1.2)$ & $0.57(0.32,1.07)$ \\
\hline & $\begin{array}{l}\text { Husband/someone } \\
\text { else only }\end{array}$ & $1.21(0.9,1.66)$ & $0.79(0.54,1.09)$ & $0.65(0.36,1.15)$ \\
\hline & Missing & & & \\
\hline \multicolumn{5}{|c|}{ Who makes decision on the woman's own health } \\
\hline & Self (ref) & & & \\
\hline & $\begin{array}{l}\text { Jointly with } \\
\text { husband/someone } \\
\text { else }\end{array}$ & $0.43(0.29,0.62)$ & $0.78(0.54,1.24)$ & $0.64(0.35,1.13)$ \\
\hline & $\begin{array}{l}\text { Husband/someone } \\
\text { else only }\end{array}$ & $0.34(0.25,0.43)$ & $0.95(0.69,1.26)$ & $1.67(1.06,2.5)$ \\
\hline & Missing & & & \\
\hline
\end{tabular}




\begin{tabular}{|c|c|c|c|c|}
\hline Predictor & Level & $\begin{array}{l}\text { Model I POR } \\
(95 \% \mathrm{Cl})\end{array}$ & Model II POR (95\% Cl) & $\begin{array}{l}\text { Model III POR } \\
(95 \% \mathrm{Cl})\end{array}$ \\
\hline \multicolumn{5}{|c|}{ WOMEN AGENCY, AND OPPORTUNITIES } \\
\hline \multicolumn{5}{|c|}{ Woman's occupation } \\
\hline & Formal (ref) & & & \\
\hline & Informal & $1.59(1.09,2.31)$ & $1.31(0.89,1.93)$ & $0.51(0.25,1.11)$ \\
\hline & Not working & $5.61(1.05,42.66)$ & $1.97(0.16,19.77)$ & $0.95(0.02,23.77)$ \\
\hline \multicolumn{5}{|c|}{ Woman employed within the last 12 months } \\
\hline & No (ref) & & & \\
\hline & Yes & $0.45(0.16,1.14)$ & $0.85(0.28,2.68)$ & $1.15(0.24,5.42)$ \\
\hline \multicolumn{5}{|c|}{ Woman's type of job } \\
\hline & $\begin{array}{l}\text { Seasonal/Part of the } \\
\text { year (ref) }\end{array}$ & & & \\
\hline & All year & $1.08(0.85,1.37)$ & $1.01(0.75,1.34)$ & $0.9(0.63,1.29)$ \\
\hline \multicolumn{5}{|c|}{ Partner's occupation } \\
\hline & Formal (ref) & & & \\
\hline & Informal & $1.13(0.86,1.52)$ & $0.83(0.6,1.16)$ & $0.65(0.42,1.02)$ \\
\hline & Not working & $14.6(2.94,69.37)$ & $10.03(1.72,69.14)$ & $\begin{array}{c}4.61(0.11 \\
146.91)\end{array}$ \\
\hline & Missing & $0.73(0.51,0.99)$ & $0.72(0.44,1.06)$ & $0.47(0.27,0.85)$ \\
\hline \multicolumn{5}{|c|}{ Type of union } \\
\hline & Polygamous (ref) & & & \\
\hline & Monogamous & $1.09(0.9,1.34)$ & $0.98(0.74,1.28)$ & $1.22(0.82,1.8)$ \\
\hline & Missing & $0.5(0.29,0.84)$ & $0.5(0.3,0.86)$ & $\begin{array}{c}8.58(0.55 \\
104.18)\end{array}$ \\
\hline \multicolumn{5}{|c|}{ Who usually decides on woman's cash spending (currently married women only) } \\
\hline & $\begin{array}{l}\text { Respondent alone } \\
\text { (ref) }\end{array}$ & & & \\
\hline
\end{tabular}




\begin{tabular}{|c|c|c|c|c|}
\hline Predictor & Level & $\begin{array}{l}\text { Model I POR } \\
(95 \% \mathrm{Cl})\end{array}$ & Model II POR (95\% Cl) & $\begin{array}{l}\text { Model III POR } \\
(95 \% \mathrm{Cl})\end{array}$ \\
\hline & $\begin{array}{l}\text { Husband/partner } \\
\text { alone }\end{array}$ & $0.83(0.55,1.27)$ & $0.44(0.28,0.69)$ & $0.8(0.45,1.54)$ \\
\hline & $\begin{array}{l}\text { Respondent and } \\
\text { husband/partner }\end{array}$ & $0.83(0.61,1.1)$ & $0.66(0.47,0.89)$ & $1.07(0.65,1.66)$ \\
\hline & Missing & $1.38(1.04,1.83)$ & $1.07(0.76,1.45)$ & $1.53(0.92,2.62)$ \\
\hline \multicolumn{5}{|c|}{ Media Information } \\
\hline \multicolumn{5}{|c|}{ Woman reads newspapers/magazines } \\
\hline & Not at all (ref) & & & \\
\hline & $\begin{array}{l}\text { Less than once a } \\
\text { week }\end{array}$ & $0.98(0.75,1.31)$ & $0.91(0.66,1.3)$ & $1.29(0.77,2.27)$ \\
\hline & At least once a week & $0.64(0.45,0.92)$ & $0.69(0.45,1.06)$ & $0.85(0.45,1.66)$ \\
\hline \multicolumn{5}{|c|}{ Woman listens to radio } \\
\hline & Not at all (ref) & & & \\
\hline & $\begin{array}{l}\text { Less than once a } \\
\text { week }\end{array}$ & $1.22(0.95,1.55)$ & $1.35(0.99,1.85)$ & $1.51(0.95,2.51)$ \\
\hline & At least once a week & $0.86(0.69,1.08)$ & $0.85(0.63,1.16)$ & $1.32(0.92,1.97)$ \\
\hline \multicolumn{5}{|c|}{ Woman watches TV } \\
\hline & Not at all (ref) & & & \\
\hline & $\begin{array}{l}\text { Less than once a } \\
\text { week }\end{array}$ & $0.77(0.57,1.01)$ & $0.52(0.36,0.77)$ & $0.72(0.44,1.21)$ \\
\hline & At least once a week & $0.92(0.75,1.11)$ & $0.74(0.56,0.99)$ & $1.37(0.86,2.31)$ \\
\hline \multicolumn{5}{|c|}{ Years lived continuously in current location } \\
\hline & 0 years (ref) & & & \\
\hline & $1-10$ years & $5.07(1.95,18.61)$ & $5.46(2,17.26)$ & $4.12(1.34,15.78)$ \\
\hline & $11-20$ years & $6.11(2.41,20.98)$ & $7.82(2.62,26.06)$ & $3.24(0.91,12)$ \\
\hline & 21 or more years & $5.68(2.1,21.04)$ & $6.92(2.17,21.11)$ & $1.33(0.34,6.46)$ \\
\hline & Missing & $4.84(1.89,16.99)$ & $7.24(2.59,22.49)$ & $3.07(0.94,11.93)$ \\
\hline
\end{tabular}


Model I: Unadjusted Model

Model II: Adjusted with Unobserved spatial location effects.

Model III: Fully adjusted spatial model with all significant potential confounders.

POR = Posterior Odds Ratio; $\mathbf{C l}=$ Credible Interval 
Table A2. Bayesian Geo-additive Multilevel Regression, 2007 MICS

\begin{tabular}{|c|c|c|c|c|}
\hline Predictor & Level & $\begin{array}{l}\text { Model I } \\
\text { POR }(95 \% \mathrm{CI})\end{array}$ & $\begin{array}{ll}\text { Model II } & \text { POR } \\
(95 \% \mathrm{Cl}) & \end{array}$ & $\begin{array}{l}\text { Model III } \\
(95 \% \mathrm{CI})\end{array}$ \\
\hline \multicolumn{5}{|c|}{ DEMOGRAPHIC } \\
\hline \multicolumn{5}{|c|}{ Place of residence } \\
\hline & Rural (ref) & & & \\
\hline & Urban & $1.23(1.09,1.37)$ & $0.86(0.75,1)$ & $0.96(0.78,1.2)$ \\
\hline \multicolumn{5}{|l|}{ Region } \\
\hline & North Central (ref) & & & \\
\hline & North East & $\begin{array}{r}0.12 \quad(0.06 \\
0.20)\end{array}$ & $0.09(0.01,0.86)$ & $0.2(0.02,0.99)$ \\
\hline & North West & $\begin{array}{l}0.35 \quad(0.24, \\
0.48)\end{array}$ & $0.66(0.08,6.2)$ & $0.8(0.19,4.62)$ \\
\hline & South East & $\begin{array}{r}1.80 \quad(1.47 \\
2.27)\end{array}$ & $2.73(0.6,13.06)$ & $1.32(0.34,5.15)$ \\
\hline & South South & $\begin{array}{r}1.14 \quad(0.95 \\
1.40)\end{array}$ & $2.02(0.5,10.75)$ & $1.14(0.3,5.7)$ \\
\hline & South West & $\begin{array}{r}3.80 \\
4.61)\end{array}$ & $\begin{array}{l}3.99(0.88 \\
22.79)\end{array}$ & $\begin{array}{l}3.21 \\
11.55)\end{array}$ \\
\hline \multicolumn{5}{|c|}{ Wealth Index } \\
\hline & Middle (ref) & & & \\
\hline & Lowest & $0.51(0.39,0.64)$ & $0.95(0.7,1.25)$ & $1.07(0.74,1.52)$ \\
\hline & Second & $0.92(0.75,1.13)$ & $1.15(0.92,1.4)$ & $1.19(0.94,1.5)$ \\
\hline & Higher & $1.36(1.14,1.6)$ & $1.01(0.84,1.25)$ & $1.14(0.89,1.42)$ \\
\hline & Highest & $0.92(0.78,1.1)$ & $0.74(0.61,0.9)$ & $0.96(0.75,1.27)$ \\
\hline \multicolumn{5}{|c|}{ Marital status } \\
\hline & $\begin{array}{ll}\text { Currently } & \text { married/in } \\
\text { union (ref) } & \end{array}$ & & & \\
\hline & Never married & $\begin{array}{c}0.94(0.61 \\
1.43)\end{array}$ & $0.79(0.49,1.22)$ & $1.17(0.64,2.07)$ \\
\hline
\end{tabular}




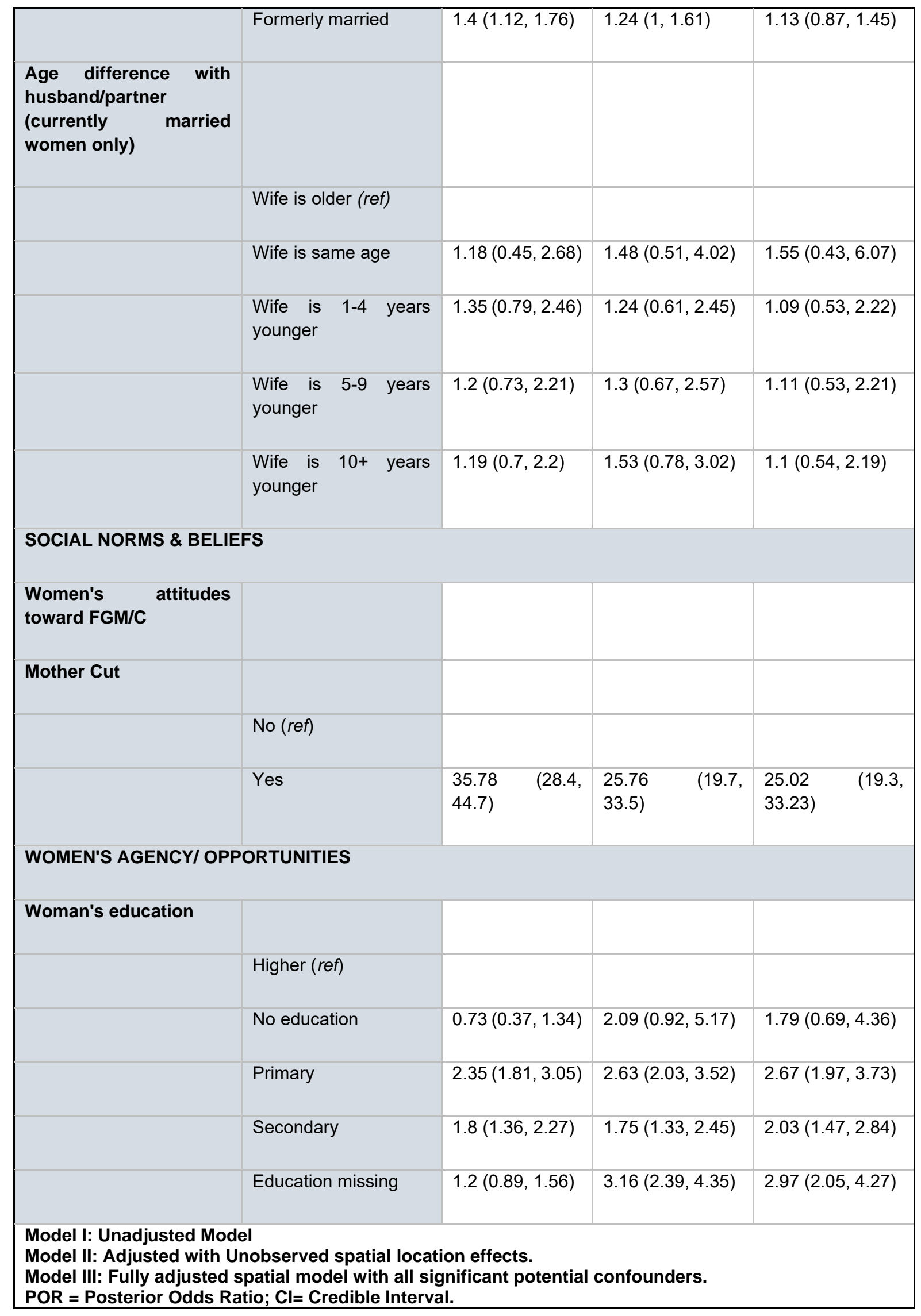


Table A3. Bayesian Geo-additive Multilevel Regression, 2008 DHS

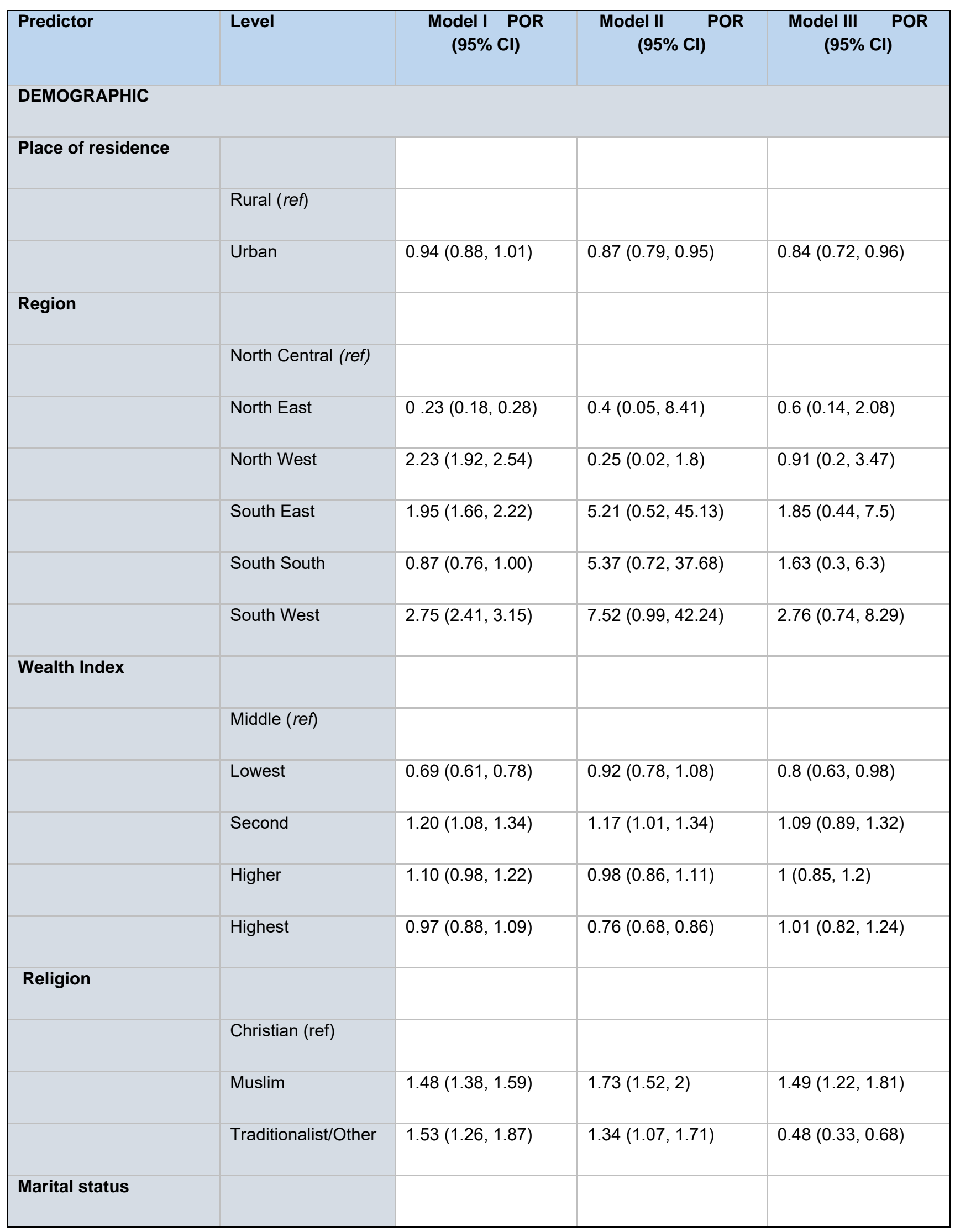




\begin{tabular}{|c|c|c|c|c|}
\hline Predictor & Level & $\begin{array}{l}\text { Model I POR } \\
(95 \% \mathrm{Cl})\end{array}$ & $\begin{array}{l}\text { Model II POR } \\
(95 \% \mathrm{CI})\end{array}$ & $\begin{array}{c}\text { Model III POR } \\
(95 \% \mathrm{Cl})\end{array}$ \\
\hline & $\begin{array}{l}\text { Currently married/in } \\
\text { union (ref) }\end{array}$ & & & \\
\hline & Never married & $0.39(0.25,0.56)$ & $0.54(0.35,0.85)$ & $3.42(0.48,33.98)$ \\
\hline & Formerly married & $1.16(0.99,1.32)$ & $1.44(1.19,1.72)$ & $3.53(0.58,18.01)$ \\
\hline \multirow[t]{6}{*}{$\begin{array}{l}\text { Age difference with } \\
\text { husband/partner } \\
\text { (currently married } \\
\text { women only) }\end{array}$} & & & & \\
\hline & Wife is older (ref) & & & \\
\hline & Wife is same age & $1.87(1.19,2.99)$ & $1.51(0.92,2.68)$ & $1.52(0.74,3.05)$ \\
\hline & $\begin{array}{l}\text { Wife is } 1-4 \text { years } \\
\text { younger }\end{array}$ & $1.61(1.09,2.39)$ & $1.07(0.7,1.61)$ & $0.82(0.46,1.47)$ \\
\hline & $\begin{array}{l}\text { Wife is } 5-9 \text { years } \\
\text { younger }\end{array}$ & $1.42(0.95,2.16)$ & $0.95(0.63,1.43)$ & $0.66(0.39,1.19)$ \\
\hline & $\begin{array}{l}\text { Wife is } 10+\text { years } \\
\text { younger }\end{array}$ & $1.61(1.12,2.4)$ & $1.02(0.68,1.56)$ & $0.72(0.42,1.31)$ \\
\hline \multicolumn{5}{|l|}{ Ethnicity } \\
\hline & Fulani (ref) & & & \\
\hline & Hausa & $2.44(1.98,2.97)$ & $0.71(0.46,1.02)$ & $0.48(0.29,0.81)$ \\
\hline & Igbo & $2.06(1.69,2.47)$ & $1.08(0.77,1.6)$ & $0.93(0.58,1.58)$ \\
\hline & Kanuri & $0.11(0.06,0.19)$ & $0.07(0.03,0.12)$ & $0.15(0.07,0.34)$ \\
\hline & Tiv & $0.05(0.02,0.12)$ & $0.12(0.04,0.35)$ & $0.42(0.11,1.68)$ \\
\hline & Yoruba & $3.85(3.12,4.72)$ & $1.43(1.05,2.02)$ & $1.22(0.79,1.89)$ \\
\hline & Other & $0.65(0.53,0.8)$ & $0.55(0.41,0.76)$ & $0.47(0.31,0.77)$ \\
\hline \multicolumn{5}{|c|}{ SOCIAL NORMS \& BELIEFS } \\
\hline \multicolumn{5}{|l|}{$\begin{array}{l}\text { Women's attitudes } \\
\text { toward FGM/C }\end{array}$} \\
\hline Mother Cut & & & & \\
\hline
\end{tabular}




\begin{tabular}{|c|c|c|c|c|}
\hline \multirow[t]{3}{*}{ Predictor } & Level & $\begin{array}{c}\text { Model I POR } \\
(95 \% \mathrm{Cl})\end{array}$ & $\begin{array}{l}\text { Model II POR } \\
(95 \% \mathrm{CI})\end{array}$ & $\begin{array}{c}\text { Model III POR } \\
(95 \% \mathrm{Cl})\end{array}$ \\
\hline & No (ref) & & & \\
\hline & Yes & $22.1(19.1,26.1)$ & $11.29(9.56,13.4)$ & $10.6(8.95,12.93)$ \\
\hline \multicolumn{5}{|l|}{ Benefit of FGM/C } \\
\hline \multicolumn{5}{|c|}{$\begin{array}{l}\text { Circumcision should } \\
\text { continue or be } \\
\text { stopped. }\end{array}$} \\
\hline & Discontinued (ref) & & & \\
\hline & Continued & $6.89(6.19,7.75)$ & $5.58(4.87,6.38)$ & $6.83(5.92,7.78)$ \\
\hline & Depends & $3.23(2.69,3.82)$ & $2.63(2.21,3.17)$ & $2.92(2.39,3.6)$ \\
\hline & Don't know & $3.47(2.84,4.27)$ & $2.13(1.71,2.62)$ & $2.38(1.9,3.01)$ \\
\hline \multicolumn{5}{|c|}{$\begin{array}{l}\text { Women's belief about } \\
\text { FGM/C }\end{array}$} \\
\hline \multicolumn{5}{|c|}{$\begin{array}{l}\text { Circumcision is } \\
\text { required by religion. }\end{array}$} \\
\hline & No (ref) & & & \\
\hline & Yes & $0.81(0.71,0.93)$ & $1.25(1.07,1.44)$ & $1.33(1.12,1.58)$ \\
\hline & Missing & $1.28(1.11,1.46)$ & $1.06(0.9,1.25)$ & $1.13(0.94,1.37)$ \\
\hline \multirow{7}{*}{$\begin{array}{l}\text { Circumcision is } \\
\text { required for }\end{array}$} & No (ref) & & & \\
\hline & Cleanliness/hygiene & $1.58(1.33,1.86)$ & $1.36(1.15,1.66)$ & $1.39(1.15,1.69)$ \\
\hline & Social acceptance & $1.68(1.45,1.89)$ & $2.00(1.7,2.34)$ & $1.91(1.63,2.23)$ \\
\hline & $\begin{array}{l}\text { Better marriage } \\
\text { prospects }\end{array}$ & $2.36(2.01,2.77)$ & $2.44(2.07,2.9)$ & $2.41(1.99,2.94)$ \\
\hline & $\begin{array}{l}\text { Virginity/prevent } \\
\text { premarital sex }\end{array}$ & $1.83(1.59,2.1)$ & $1.92(1.65,2.22)$ & $2.02(1.73,2.41)$ \\
\hline & $\begin{array}{l}\text { More sexual } \\
\text { pleasure for men }\end{array}$ & $2.94(2.43,3.62)$ & $1.62(1.29,2.01)$ & $1.96(1.5,2.59)$ \\
\hline & Religious approval & $0.95(0.73,1.2)$ & $0.9(0.69,1.2)$ & $1.02(0.75,1.37)$ \\
\hline
\end{tabular}




\begin{tabular}{|c|c|c|c|c|}
\hline Predictor & Level & $\begin{array}{l}\text { Model I POR } \\
(95 \% \mathrm{Cl})\end{array}$ & $\begin{array}{c}\text { Model II POR } \\
(95 \% \mathrm{Cl})\end{array}$ & $\begin{array}{c}\text { Model III POR } \\
(95 \% \mathrm{CI})\end{array}$ \\
\hline \multicolumn{5}{|c|}{ WOMEN'S AGENCY/ OPPORTUNITIES } \\
\hline \multirow[t]{4}{*}{ Woman's education } & Higher (ref) & & & \\
\hline & No education & $1.75(1.52,2.03)$ & $2.69(2.26,3.27)$ & $1.23(0.85,1.77)$ \\
\hline & Primary & $1.85(1.6,2.19)$ & $2.2(1.88,2.61)$ & $1.22(0.88,1.75)$ \\
\hline & Secondary & $1.65(1.42,1.92)$ & $1.85(1.58,2.19)$ & $1.26(0.94,1.74)$ \\
\hline \multirow[t]{5}{*}{$\begin{array}{l}\text { Husband's/partner's } \\
\text { education (currently } \\
\text { married women only) }\end{array}$} & & & & \\
\hline & Higher (ref) & & & \\
\hline & No education & $1.71(1.45,1.99)$ & $2.09(1.72,2.54)$ & $1.32(1.01,1.72)$ \\
\hline & Primary & $2.05(1.73,2.33)$ & $1.91(1.6,2.26)$ & $1.4(1.12,1.79)$ \\
\hline & Secondary & $1.73(1.51,1.97)$ & $1.53(1.32,1.8)$ & $1.34(1.05,1.67)$ \\
\hline \multicolumn{5}{|c|}{ GENDER NORMS \& BASED VIOLENCE } \\
\hline \multirow{6}{*}{$\begin{array}{l}\text { Husband is justified in } \\
\text { hitting or beating his } \\
\text { wife if she: }\end{array}$} & No (ref) & & & \\
\hline & $\begin{array}{l}\text { Goes out without } \\
\text { telling him }\end{array}$ & $0.87(0.76,0.98)$ & $1.04(0.89,1.21)$ & $1.03(0.85,1.27)$ \\
\hline & Neglects children & $1.03(0.9,1.18)$ & $1.02(0.88,1.19)$ & $1.11(0.92,1.34)$ \\
\hline & Argues with him & $1.24(1.11,1.4)$ & $1.44(1.24,1.7)$ & $1.43(1.16,1.78)$ \\
\hline & $\begin{array}{l}\text { Refuses to have sex } \\
\text { with him }\end{array}$ & $0.56(0.5,0.63)$ & $0.67(0.56,0.78)$ & $0.6(0.49,0.73)$ \\
\hline & Burns the food & $1.4(1.23,1.59)$ & $1.06(0.9,1.25)$ & $1.11(0.9,1.39)$ \\
\hline \multicolumn{5}{|l|}{$\begin{array}{l}\text { Final say in making } \\
\text { specific decisions: }\end{array}$} \\
\hline \multirow[t]{2}{*}{$\begin{array}{l}\text { Who makes decision } \\
\text { on large household } \\
\text { purchase }\end{array}$} & & & & \\
\hline & Self (ref) & & & \\
\hline
\end{tabular}




\begin{tabular}{|c|c|c|c|c|}
\hline Predictor & Level & $\begin{array}{c}\text { Model I POR } \\
(95 \% \mathrm{Cl})\end{array}$ & $\begin{array}{c}\text { Model II POR } \\
(95 \% \mathrm{Cl})\end{array}$ & $\begin{array}{c}\text { Model III POR } \\
(95 \% \mathrm{Cl})\end{array}$ \\
\hline & $\begin{array}{l}\text { Jointly with } \\
\text { husband/someone } \\
\text { else }\end{array}$ & $1.28(1.03,1.58)$ & $1.19(0.92,1.5)$ & $1.54(1.13,2.1)$ \\
\hline & $\begin{array}{l}\text { Husband/someone } \\
\text { else only }\end{array}$ & $1.16(0.98,1.4)$ & $0.94(0.76,1.16)$ & $1(0.72,1.31)$ \\
\hline & Missing & $1.42(0.53,4.22)$ & $1.42(0.43,4.23)$ & $0.85(0.15,3.97)$ \\
\hline \multicolumn{5}{|l|}{$\begin{array}{l}\text { Who makes decision } \\
\text { on small household } \\
\text { purchase }\end{array}$} \\
\hline & Self $(r e f)$ & & & \\
\hline & $\begin{array}{l}\text { Jointly with } \\
\text { husband/someone } \\
\text { else }\end{array}$ & $1.22(1.06,1.41)$ & $0.9(0.76,1.06)$ & $0.73(0.58,0.92)$ \\
\hline & $\begin{array}{l}\text { Husband/someone } \\
\text { else only }\end{array}$ & $1.48(1.29,1.72)$ & $1.14(0.98,1.34)$ & $1.26(1.03,1.54)$ \\
\hline & Missing & $1.01(0.44,2.18)$ & $0.7(0.26,2)$ & $0.31(0.04,2.49)$ \\
\hline \multicolumn{5}{|l|}{$\begin{array}{l}\text { Who makes decision } \\
\text { on the woman's own } \\
\text { health }\end{array}$} \\
\hline & Self $(r e f)$ & & & \\
\hline & $\begin{array}{l}\text { Jointly with } \\
\text { husband/someone } \\
\text { else }\end{array}$ & $0.61(0.53,0.72)$ & $0.97(0.83,1.16)$ & $0.82(0.64,1.01)$ \\
\hline & $\begin{array}{l}\text { Husband/someone } \\
\text { else only }\end{array}$ & $0.73(0.63,0.86)$ & $1.01(0.87,1.2)$ & $0.88(0.7,1.08)$ \\
\hline & Missing & $0.78(0.3,1.83)$ & $1.17(0.33,3.5)$ & $1.7(0.21,10.18)$ \\
\hline \multicolumn{5}{|c|}{ WOMEN AGENCY, OPPORTUNITIES AND GENDER BASED VIOLENCE } \\
\hline $\begin{array}{l}\text { Employment and } \\
\text { earnings }\end{array}$ & & & & \\
\hline \multicolumn{5}{|l|}{$\begin{array}{l}\text { Woman currently } \\
\text { employed (last } 7 \text { days) }\end{array}$} \\
\hline & No $(r e f)$ & & & \\
\hline
\end{tabular}




\begin{tabular}{|c|c|c|c|c|}
\hline Predictor & Level & $\begin{array}{c}\text { Model I POR } \\
(95 \% \mathrm{Cl})\end{array}$ & $\begin{array}{c}\begin{array}{c}\text { Model II } \\
(95 \% \mathrm{Cl})\end{array} \\
\text { POR }\end{array}$ & $\begin{array}{c}\text { Model III POR } \\
(95 \% \mathrm{Cl})\end{array}$ \\
\hline & Yes & $0.59(0.03,7.58)$ & $0.01(0,0.13)$ & $0.08(0,5.59)$ \\
\hline \multicolumn{5}{|c|}{ Woman's occupation } \\
\hline & Formal (ref) & & & \\
\hline & Informal & $1.45(1.21,1.7)$ & $1.37(1.13,1.7)$ & $1.22(0.9,1.55)$ \\
\hline & Not working & $0.56(0.23,1.38)$ & $1.09(0.29,3.74)$ & $1.84(0.43,6.33)$ \\
\hline \multicolumn{5}{|c|}{$\begin{array}{l}\text { Woman employed } \\
\text { within the last } 12 \\
\text { months }\end{array}$} \\
\hline & No $(r e f)$ & & & \\
\hline & Yes & $0.9(0.04,11.55)$ & $0.00(0.00,0.11)$ & $0.05(0.00,3.54)$ \\
\hline \multicolumn{5}{|c|}{ Woman's type of job } \\
\hline & $\begin{array}{l}\text { Seasonal/Part of the } \\
\text { year (ref) }\end{array}$ & & & \\
\hline & All year & $1.63(1.46,1.8)$ & $0.87(0.76,1)$ & $0.91(0.77,1.09)$ \\
\hline & Missing & $0.82(0.38,1.71)$ & $0.22(0.08,0.65)$ & $0.16(0.04,0.53)$ \\
\hline \multicolumn{5}{|c|}{ Worked for cash } \\
\hline & Not paid at all (ref) & & & \\
\hline & In kind only & $0.59(0.33,0.95)$ & $0.9(0.5,1.65)$ & $0.8(0.36,1.74)$ \\
\hline & Cash only & $1.22(0.96,1.61)$ & $1.26(0.9,1.78)$ & $0.74(0.47,1.17)$ \\
\hline & Cash and kind & $1.02(0.76,1.33)$ & $1.48(1.02,2.1)$ & $0.85(0.52,1.5)$ \\
\hline & Missing & $2.99(1.42,6.17)$ & $5.94(1.67,17.9)$ & $6.52(1.77,23.5)$ \\
\hline \multicolumn{5}{|c|}{ Partner's occupation } \\
\hline & Formal (ref) & & & \\
\hline & Informal & $1.08(0.96,1.23)$ & $1.01(0.88,1.18)$ & $1.09(0.91,1.3)$ \\
\hline & Missing & $0.63(0.45,0.9)$ & $0.62(0.42,0.92)$ & $0.53(0.24,1.11)$ \\
\hline Type of un & & & & \\
\hline
\end{tabular}




\begin{tabular}{|c|c|c|c|c|}
\hline Predictor & Level & $\begin{array}{l}\text { Model I POR } \\
(95 \% \mathrm{Cl})\end{array}$ & $\begin{array}{c}\text { Model II POR } \\
(95 \% \mathrm{Cl})\end{array}$ & $\begin{array}{c}\text { Model III POR } \\
(95 \% \mathrm{CI})\end{array}$ \\
\hline & Polygamous (ref) & & & \\
\hline & Monogamous & $0.88(0.82,0.96)$ & $0.87(0.78,0.97)$ & $1.16(0.97,1.32)$ \\
\hline & Missing & $1.01(0.63,1.67)$ & $0.92(0.53,1.55)$ & $1.08(0.43,2.49)$ \\
\hline \multirow[t]{5}{*}{$\begin{array}{l}\text { Who usually decid } \\
\text { on woman's cash } \\
\text { spending (currentl/ } \\
\text { married women on }\end{array}$} & & & & \\
\hline & $\begin{array}{l}\text { Respondent alone } \\
\text { (ref) }\end{array}$ & & & \\
\hline & $\begin{array}{l}\text { Husband/partner } \\
\text { alone }\end{array}$ & $0.99(0.86,1.14)$ & $0.75(0.62,0.89)$ & $0.98(0.77,1.25)$ \\
\hline & $\begin{array}{l}\text { Respondent and } \\
\text { husband/partner }\end{array}$ & $0.97(0.86,1.09)$ & $0.84(0.72,0.98)$ & $0.72(0.59,0.88)$ \\
\hline & Missing & $0.81(0.62,1.04)$ & $1.1(0.79,1.51)$ & $0.79(0.51,1.2)$ \\
\hline \multicolumn{5}{|c|}{ ACTUAL WOMEN MOBILITY, MIXED ETHNICITY \& MEDIA INFORMATION } \\
\hline \multirow[t]{6}{*}{$\begin{array}{l}\text { Years lived } \\
\text { continuously in } \\
\text { current location }\end{array}$} & & & & \\
\hline & 0 years (ref) & & & \\
\hline & $1-10$ years & $0.99(0.81,1.19)$ & $1.11(0.86,1.44)$ & $1.07(0.79,1.46)$ \\
\hline & $11-20$ years & $0.99(0.8,1.22)$ & $1.53(1.18,2)$ & $1.24(0.87,1.73)$ \\
\hline & 21 or more years & $0.81(0.64,1.03)$ & $1.72(1.21,2.33)$ & $1.29(0.83,1.97)$ \\
\hline & Missing & $1.2(0.98,1.48)$ & $1.46(1.12,1.9)$ & $1.34(0.95,1.82)$ \\
\hline \multirow[t]{4}{*}{$\begin{array}{l}\text { Respondent from } \\
\text { mixed ethnicity }\end{array}$} & & & & \\
\hline & Mixed (ref) & & & \\
\hline & Same & $2.11(1.7,2.65)$ & $1.66(1.27,2.23)$ & $1.04(0.73,1.54)$ \\
\hline & Missing & $1.75(1.41,2.14)$ & $1.39(1.07,1.85)$ & $0.81(0.57,1.21)$ \\
\hline
\end{tabular}




\begin{tabular}{|c|c|c|c|c|}
\hline Predictor & Level & $\begin{array}{l}\text { Model I POR } \\
(95 \% \mathrm{Cl})\end{array}$ & $\begin{array}{l}\text { Model II POR } \\
(95 \% \mathrm{Cl})\end{array}$ & $\begin{array}{c}\text { Model III POR } \\
(95 \% \mathrm{Cl})\end{array}$ \\
\hline \multicolumn{5}{|c|}{ Media Information } \\
\hline \multicolumn{5}{|c|}{$\begin{array}{l}\text { Woman reads } \\
\text { newspapers/ } \\
\text { magazines }\end{array}$} \\
\hline & \multicolumn{2}{|l|}{ Not at all (ref) } & & \\
\hline & $\begin{array}{l}\text { Less than once a } \\
\text { week }\end{array}$ & $0.71(0.62,0.8)$ & $0.69(0.59,0.8)$ & $0.83(0.68,1.02)$ \\
\hline & At least once a week & $0.65(0.58,0.74)$ & $0.7(0.6,0.82)$ & $1.17(0.94,1.46)$ \\
\hline \multicolumn{5}{|c|}{ Woman listens to radio } \\
\hline & \multicolumn{2}{|l|}{ Not at all (ref) } & & \\
\hline & $\begin{array}{l}\text { Less than once a } \\
\text { week }\end{array}$ & $1.67(1.49,1.85)$ & $1.21(1.05,1.41)$ & $1.12(0.89,1.36)$ \\
\hline & At least once a week & $1.72(1.57,1.88)$ & $1.21(1.06,1.36)$ & $1.13(0.94,1.37)$ \\
\hline \multicolumn{5}{|c|}{ Woman watches TV } \\
\hline & \multicolumn{2}{|l|}{ Not at all (ref) } & & \\
\hline & $\begin{array}{l}\text { Less than once a } \\
\text { week }\end{array}$ & $0.89(0.8,1.01)$ & $0.82(0.72,0.94)$ & $0.87(0.71,1.07)$ \\
\hline & At least once a week & $0.93(0.85,1.01)$ & $0.82(0.74,0.92)$ & $0.93(0.77,1.16)$ \\
\hline \multicolumn{5}{|c|}{$\begin{array}{l}\text { Model I: Unadjusted Model } \\
\text { Model II: Adjusted with Unobserved spatial location effects. } \\
\text { Model III: Fully adjusted spatial model with all significant potential confounders. } \\
\text { POR = Posterior Odds Ratio; } \mathrm{Cl}=\text { Credible Interval. }\end{array}$} \\
\hline
\end{tabular}


Table A4. Bayesian Geo-additive Multilevel Regression, 2011 MICS

\begin{tabular}{|c|c|c|c|c|}
\hline Predictor & Level & $\begin{array}{l}\text { Model I } \quad \text { POR } \\
(95 \% \mathrm{Cl})\end{array}$ & $\begin{array}{l}\text { Model II } \quad \text { POR } \\
(95 \% \mathrm{Cl})\end{array}$ & $\begin{array}{l}\text { Model III POR } \\
(95 \% \mathrm{Cl})\end{array}$ \\
\hline \multicolumn{5}{|c|}{ DEMOGRAPHIC } \\
\hline \multicolumn{5}{|c|}{ Place of residence } \\
\hline & Rural (ref) & & & \\
\hline & Urban & $1.00(0.91,1.10)$ & $0.63(0.56,0.70)$ & $0.75(0.64,0.89)$ \\
\hline \multicolumn{5}{|l|}{ Region } \\
\hline & North Central (ref) & & & \\
\hline & North East & $0.31(0.22,0.40)$ & $0.13(0.02,1.04)$ & $0.19(0.04,1.04)$ \\
\hline & North West & $4.89(4.25,5.67)$ & $12.45(2.1,68.73)$ & $3.86(1.18,12.16)$ \\
\hline & South East & $1.39(1.18,1.65)$ & $0.78(0.12,2.82)$ & $2.09(0.31,10.31)$ \\
\hline & South South & $1.10(0.95,1.29)$ & $0.99(0.14,8.30)$ & $2.16(0.46,13.28)$ \\
\hline & South West & $3.41(3.01,3.98)$ & $2.68(0.7,17.11)$ & $4.4(1.02,17.65)$ \\
\hline \multicolumn{5}{|c|}{ Wealth Index } \\
\hline & Middle (ref) & & & \\
\hline & Lowest & $1.03(0.92,1.16)$ & $1.48(1.26,1.71)$ & $0.94(0.75,1.19)$ \\
\hline & Second & $0.93(0.82,1.08)$ & $1.08(0.93,1.26)$ & $0.82(0.68,1.00)$ \\
\hline & Higher & $0.94(0.84,1.06)$ & $0.88(0.76,1.02)$ & $1.02(0.85,1.19)$ \\
\hline & Highest & $0.53(0.46,0.62)$ & $0.54(0.46,0.64)$ & $0.96(0.77,1.19)$ \\
\hline \multicolumn{5}{|l|}{ Religion } \\
\hline & Christian (ref) & & & \\
\hline & Muslim & $1.94(1.78,2.13)$ & $2.55(2.17,2.92)$ & $2.14(1.80,2.64)$ \\
\hline & Traditionalist/Other & $2.57(1.94,3.59)$ & $3.09(2.27,4.12)$ & $2.86(1.87,4.26)$ \\
\hline Marital sta & & & & \\
\hline
\end{tabular}




\begin{tabular}{|c|c|c|c|c|}
\hline Predictor & Level & $\begin{array}{l}\text { Model I } \quad \text { POR } \\
(95 \% \mathrm{Cl})\end{array}$ & $\begin{array}{l}\text { Model II } \quad \text { POR } \\
(95 \% \mathrm{Cl})\end{array}$ & $\begin{array}{l}\text { Model III POR } \\
(95 \% \mathrm{CI})\end{array}$ \\
\hline & $\begin{array}{l}\text { Currently married/in union } \\
\text { (ref) }\end{array}$ & & & \\
\hline & Never married & $0.53(0.31,0.82)$ & $0.85(0.53,1.42)$ & $1.15(0.62,2.11)$ \\
\hline & Formerly married & $0.71(0.58,0.86)$ & $0.80(0.63,1.01)$ & $1.02(0.79,1.31)$ \\
\hline \multicolumn{5}{|l|}{$\begin{array}{l}\text { Age difference with } \\
\text { husband/partner } \\
\text { (currently married } \\
\text { women only) }\end{array}$} \\
\hline & Wife is older (ref) & & & \\
\hline & Wife is same age & $1.91(1.11,3.40)$ & $1.44(0.80,2.54)$ & $2.30(1.12,4.98)$ \\
\hline & Wife is $1-4$ years younger & $1.32(0.92,1.90)$ & $0.98(0.64,1.43)$ & $1.19(0.74,2.00)$ \\
\hline & Wife is $5-9$ years younger & $1.25(0.90,1.79)$ & $1.00(0.68,1.47)$ & $1.24(0.83,2.05)$ \\
\hline & Wife is $10+$ years younger & $1.52(1.09,2.21)$ & $1.17(0.76,1.70)$ & $1.36(0.89,2.14)$ \\
\hline \multicolumn{5}{|c|}{ SOCIAL NORMS \& BELIEFS } \\
\hline \multicolumn{5}{|l|}{$\begin{array}{l}\text { Women's attitudes } \\
\text { toward FGM/C }\end{array}$} \\
\hline \multicolumn{5}{|l|}{ Mother Cut } \\
\hline & No (ref) & & & \\
\hline & Yes & $7.80(6.76,8.77)$ & $9.27(7.8,11.22)$ & $9.32(7.84,11.21)$ \\
\hline \multicolumn{5}{|l|}{ Benefit of FGM/C } \\
\hline \multicolumn{5}{|l|}{$\begin{array}{l}\text { Circumcision should } \\
\text { continue or be } \\
\text { stopped. }\end{array}$} \\
\hline & Discontinued (ref) & & & \\
\hline & Continued & $\begin{array}{l}11.26 \quad(10.03 \\
12.57)\end{array}$ & $9.74(8.6,10.97)$ & $9.56(8.5,10.82)$ \\
\hline & Depends/ Don't know & $2.14(1.85,2.57)$ & $1.71(1.42,2.09)$ & $1.63(1.34,1.98)$ \\
\hline WOMEN'S AGENCY/O & PPORTUNITIES & & & \\
\hline
\end{tabular}




\begin{tabular}{|c|c|c|c|c|}
\hline Predictor & Level & $\begin{array}{l}\text { Model I } \quad \text { POR } \\
(95 \% \mathrm{Cl})\end{array}$ & $\begin{array}{l}\text { Model II } \quad \text { POR } \\
(95 \% \mathrm{Cl})\end{array}$ & $\begin{array}{l}\text { Model III } \quad \text { POR } \\
(95 \% \mathrm{Cl})\end{array}$ \\
\hline \multicolumn{5}{|l|}{ Woman's education } \\
\hline & Higher (ref) & & & \\
\hline & No education & $4.04(3.00,5.41)$ & $4.95(4.95,4.95)$ & $2.70(1.64,4.67)$ \\
\hline & Primary & $2.30(1.88,2.84)$ & $3.13(3.13,3.13)$ & $1.97(1.50,2.62)$ \\
\hline & Secondary & $2.42(1.98,2.93)$ & $2.71(2.71,2.71)$ & $2.05(1.62,2.63)$ \\
\hline & Missing & $3.12(2.57,3.79)$ & $4.55(4.55,4.55)$ & $2.53(1.89,3.40)$ \\
\hline \multicolumn{5}{|c|}{ GENDER NORMS \& BASED VIOLENCE } \\
\hline \multirow{6}{*}{$\begin{array}{l}\text { Husband is justified } \\
\text { in hitting or beating } \\
\text { his wife if she: }\end{array}$} & No (ref) & & & \\
\hline & Goes out without telling him & $0.72(0.62,0.83)$ & $0.94(0.82,1.09)$ & $0.92(0.77,1.09)$ \\
\hline & Neglects children & $1.14(1.00,1.30)$ & $1.02(0.90,1.19)$ & $0.89(0.73,1.07)$ \\
\hline & Argues with him & $1.67(1.47,1.87)$ & $1.64(1.43,1.89)$ & $1.27(1.06,1.50)$ \\
\hline & $\begin{array}{l}\text { Refuses to have sex with } \\
\text { him }\end{array}$ & $1.39(1.21,1.58)$ & $1.31(1.13,1.51)$ & $1.37(1.16,1.65)$ \\
\hline & Burns the food & $0.94(0.82,1.08)$ & $1.02(0.87,1.20)$ & $1.03(0.84,1.28)$ \\
\hline \multicolumn{5}{|c|}{$\begin{array}{l}\text { Model I: Unadjusted Model } \\
\text { Model II: Adjusted with Unobserved spatial location effects. } \\
\text { Model III: Fully adjusted spatial model with all significant potential confounders. } \\
\text { POR = Posterior Odds Ratio; Cl= Credible Interval. }\end{array}$} \\
\hline
\end{tabular}


Table A5. Bayesian Geo-additive Multilevel Regression, 2013 DHS

\begin{tabular}{|c|c|c|c|c|}
\hline Predictor & Level & $\begin{array}{l}\text { Model I POR } \\
(95 \% \mathrm{Cl})\end{array}$ & $\begin{array}{l}\text { Model II POR } \\
(95 \% \mathrm{Cl})\end{array}$ & $\begin{array}{c}\text { Model III POR } \\
(95 \% \mathrm{Cl})\end{array}$ \\
\hline \multicolumn{5}{|c|}{ DEMOGRAPHIC } \\
\hline \multicolumn{5}{|c|}{ Place of residence } \\
\hline & Rural (ref) & & & \\
\hline & Urban & $0.83(0.78,0.89)$ & $0.66(0.61,0.71)$ & $0.82(0.71,0.94)$ \\
\hline \multicolumn{5}{|l|}{ Region } \\
\hline & North Central (ref) & & & \\
\hline & North East & $0.54(0.45,0.64)$ & $0.96(0.18,7.11)$ & $0.83(0.2,3.24)$ \\
\hline & North West & $3.14(2.75,3.60)$ & $5.10(1.20,20.81)$ & $2.13(0.51,8.84)$ \\
\hline & South East & $1.57(1.34,1.85)$ & $4.57(0.68,42.47)$ & $1.43(0.31,6.56)$ \\
\hline & South South & $0.46(0.39,0.55)$ & $0.95(0.19,5.29)$ & $1.15(0.27,5.34)$ \\
\hline & South West & $2.38(2.06,2.76)$ & $5.72(1.24,33.38)$ & $1.66(0.38,6.87)$ \\
\hline \multicolumn{5}{|c|}{ Wealth Index } \\
\hline & Middle (ref) & & & \\
\hline & Lowest & $1.52(1.38,1.66)$ & $1.52(1.35,1.69)$ & $1.04(0.85,1.28)$ \\
\hline & Second & $1.51(1.38,1.66)$ & $1.40(1.24,1.56)$ & $0.97(0.81,1.16)$ \\
\hline & Higher & $0.97(0.88,1.06)$ & $0.77(0.69,0.85)$ & $0.84(0.71,0.99)$ \\
\hline & Highest & $0.72(0.65,0.79)$ & $0.58(0.52,0.66)$ & $0.82(0.67,1)$ \\
\hline \multicolumn{5}{|l|}{ Religion } \\
\hline & Christian (ref) & & & \\
\hline & Muslim & $2.41(2.26,2.59)$ & $3.61(3.14,4.06)$ & $1.92(1.55,2.38)$ \\
\hline & Traditionalist/Other & $1.28(0.91,1.82)$ & $1.94(1.38,2.82)$ & $0.53(0.31,0.93)$ \\
\hline Marital sta & & & & \\
\hline
\end{tabular}




\begin{tabular}{|c|c|c|c|c|}
\hline Predictor & Level & $\begin{array}{l}\text { Model I POR } \\
(95 \% \mathrm{CI})\end{array}$ & $\begin{array}{l}\text { Model II POR } \\
(95 \% \mathrm{Cl})\end{array}$ & $\begin{array}{c}\text { Model III POR } \\
(95 \% \mathrm{Cl})\end{array}$ \\
\hline & $\begin{array}{l}\text { Currently } \\
\text { married/in union } \\
(\text { ref })\end{array}$ & & & \\
\hline & Never married & $0.34(0.21,0.52)$ & $0.52(0.33,0.82)$ & $0.23(0.05,1.42)$ \\
\hline & Formerly married & $0.78(0.67,0.90)$ & $0.88(0.76,1.04)$ & $0.23(0.05,1.16)$ \\
\hline \multicolumn{5}{|l|}{$\begin{array}{l}\text { Age difference with } \\
\text { husband/partner } \\
\text { (currently married women } \\
\text { only) }\end{array}$} \\
\hline & Wife is older (ref) & & & \\
\hline & Wife is same age & $0.48(0.28,0.83)$ & $0.48(0.27,0.81)$ & $0.31(0.15,0.59)$ \\
\hline & $\begin{array}{l}\text { Wife is } 1-4 \text { years } \\
\text { younger }\end{array}$ & $0.57(0.37,0.86)$ & $0.51(0.33,0.82)$ & $0.39(0.24,0.65)$ \\
\hline & $\begin{array}{l}\text { Wife is } 5-9 \text { years } \\
\text { younger }\end{array}$ & $0.65(0.44,0.99)$ & $0.58(0.39,0.92)$ & $0.44(0.27,0.73)$ \\
\hline & $\begin{array}{l}\text { Wife is } 10+\text { years } \\
\text { younger }\end{array}$ & $0.65(0.44,1.01)$ & $0.55(0.36,0.88)$ & $0.42(0.26,0.67)$ \\
\hline \multicolumn{5}{|l|}{ Ethnicity } \\
\hline & Fulani (ref) & & & \\
\hline & Hausa & $1.13(0.99,1.27)$ & $0.8(0.69,0.93)$ & $1.2(0.89,1.55)$ \\
\hline & Igbo & $0.60(0.52,0.69)$ & $0.63(0.47,0.83)$ & $1.51(0.92,2.41)$ \\
\hline & Kanuri & $0.20(0.13,0.28)$ & $0.79(0.49,1.12)$ & $0.98(0.45,2.03)$ \\
\hline & Tiv & $0.02(0.00,0.08)$ & $0.04(0.01,0.15)$ & $0.82(0.14,3.22)$ \\
\hline & Yoruba & $1.30(1.15,1.48)$ & $1.48(1.19,1.82)$ & $1.60(1.05,2.50)$ \\
\hline & Other & $0.17(0.15,0.19)$ & $0.27(0.22,0.32)$ & $0.44(0.3,0.67)$ \\
\hline \multicolumn{5}{|l|}{ SOCIAL NORMS \& BELIEFS } \\
\hline \multicolumn{5}{|l|}{$\begin{array}{l}\text { Women's } \\
\text { toward FGM/C }\end{array}$} \\
\hline Mother Cut & & & & \\
\hline
\end{tabular}




\begin{tabular}{|c|c|c|c|c|}
\hline Predictor & Level & $\begin{array}{l}\text { Model I POR } \\
(95 \% \mathrm{Cl})\end{array}$ & $\begin{array}{l}\text { Model II POR } \\
\qquad(95 \% \mathrm{Cl})\end{array}$ & $\begin{array}{c}\text { Model III POR } \\
(95 \% \mathrm{Cl})\end{array}$ \\
\hline & No (ref) & & & \\
\hline & Yes & $8.46(7.68,9.22)$ & $12.19(10.8,13.82)$ & $12.26(10.32,14.41)$ \\
\hline \multicolumn{5}{|l|}{ Benefit of FGM/C } \\
\hline \multicolumn{5}{|c|}{$\begin{array}{l}\text { Circumcision should } \\
\text { continue or be stopped. }\end{array}$} \\
\hline & Discontinued (ref) & & & \\
\hline & Continued & $9.42(8.65,10.35)$ & $10.09(9.17,11.1)$ & $10.25(9.05,11.82)$ \\
\hline & Depends & $3.57(3.10,4.16)$ & $2.96(2.52,3.49)$ & $2.79(2.28,3.35)$ \\
\hline & Don't know & $1.85(1.42,2.43)$ & $2.07(1.46,2.78)$ & $2.1(1.37,3.17)$ \\
\hline \multicolumn{5}{|c|}{$\begin{array}{l}\text { Circumcision is required } \\
\text { by religion. }\end{array}$} \\
\hline & No (ref) & & & \\
\hline & Yes & $1.66(1.49,1.87)$ & $1.72(1.52,1.99)$ & $1.71(1.48,2)$ \\
\hline & Missing & $1.36(1.21,1.54)$ & $0.94(0.82,1.1)$ & $1.01(0.88,1.18)$ \\
\hline \multicolumn{5}{|c|}{ WOMEN'S AGENCY/ OPPORTUNITIES } \\
\hline \multirow[t]{4}{*}{ Woman's education } & Higher (ref) & & & \\
\hline & No education & $3.20(2.74,3.71)$ & $3.84(3.19,4.67)$ & $1.44(0.99,2.06)$ \\
\hline & Primary & $2.17(1.85,2.58)$ & $2.76(2.3,3.3)$ & $1.53(1.16,2.18)$ \\
\hline & Secondary & $1.85(1.57,2.17)$ & $1.96(1.65,2.35)$ & $1.41(1.08,1.9)$ \\
\hline \multicolumn{5}{|c|}{$\begin{array}{l}\text { Husband's/partner's } \\
\text { education (currently } \\
\text { married women only) }\end{array}$} \\
\hline & Higher (ref) & & & \\
\hline & No education & $2.13(1.82,2.49)$ & $2.25(1.89,2.63)$ & $1.2(0.94,1.51)$ \\
\hline & Primary & $1.62(1.40,1.9)$ & $1.74(1.45,2.05)$ & $1.12(0.90,1.45)$ \\
\hline & Secondary & $1.27(1.10,1.46)$ & $1.32(1.13,1.56)$ & $0.98(0.77,1.21)$ \\
\hline \multicolumn{5}{|c|}{ GENDER NORMS \& BASED VIOLENCE } \\
\hline
\end{tabular}




\begin{tabular}{|c|c|c|c|c|}
\hline Predictor & Level & $\begin{array}{l}\text { Model I POR } \\
(95 \% \mathrm{Cl})\end{array}$ & $\begin{array}{l}\text { Model II POR } \\
(95 \% \mathrm{Cl})\end{array}$ & $\begin{array}{l}\text { Model III POR } \\
(95 \% \mathrm{Cl})\end{array}$ \\
\hline \multirow{6}{*}{$\begin{array}{l}\text { Husband is justified in } \\
\text { hitting or beating his wife } \\
\text { if she: }\end{array}$} & No (ref) & & & \\
\hline & $\begin{array}{l}\text { Goes out without } \\
\text { telling him }\end{array}$ & $0.89(0.78,1.01)$ & $1.02(0.9,1.18)$ & $0.92(0.74,1.12)$ \\
\hline & Neglects children & $1.06(0.92,1.21)$ & $1.11(0.94,1.28)$ & $1.09(0.88,1.33)$ \\
\hline & Argues with him & $1.26(1.11,1.45)$ & $1.06(0.9,1.24)$ & $0.91(0.74,1.15)$ \\
\hline & $\begin{array}{l}\text { Refuses to have } \\
\text { sex with him }\end{array}$ & $1.01(0.89,1.14)$ & $1.17(1.01,1.35)$ & $1.15(0.92,1.42)$ \\
\hline & Burns the food & $0.84(0.73,0.97)$ & $0.8(0.68,0.94)$ & $0.62(0.48,0.77)$ \\
\hline \multicolumn{5}{|l|}{$\begin{array}{l}\text { Final say in making } \\
\text { specific decisions: }\end{array}$} \\
\hline \multicolumn{5}{|l|}{$\begin{array}{l}\text { Who makes decision on } \\
\text { large household } \\
\text { purchase }\end{array}$} \\
\hline & Self (ref) & & & \\
\hline & $\begin{array}{l}\text { Jointly with } \\
\text { husband/someone } \\
\text { else }\end{array}$ & $1.38(1.18,1.64)$ & $1.18(0.98,1.47)$ & $1.12(0.87,1.45)$ \\
\hline & $\begin{array}{l}\text { Husband/someone } \\
\text { else only }\end{array}$ & $1.51(1.30,1.77)$ & $1.17(0.94,1.51)$ & $1.29(1.01,1.65)$ \\
\hline & Missing & $1.5(0.63,3.70)$ & $1.18(0.44,3.34)$ & $0.55(0.14,2.23)$ \\
\hline \multicolumn{5}{|l|}{$\begin{array}{l}\text { Who makes decision on } \\
\text { the woman's own health }\end{array}$} \\
\hline & Self (ref) & & & \\
\hline & $\begin{array}{l}\text { Jointly with } \\
\text { husband/someone } \\
\text { else }\end{array}$ & $0.71(0.61,0.83)$ & $0.93(0.78,1.13)$ & $1.01(0.80,1.29)$ \\
\hline & $\begin{array}{l}\text { Husband/someone } \\
\text { else only }\end{array}$ & $0.68(0.57,0.80)$ & $0.89(0.74,1.07)$ & $0.75(0.58,0.95)$ \\
\hline & Missing & $1.11(0.48,2.69)$ & $1.17(0.41,2.96)$ & $4.55(1.02,15.65)$ \\
\hline \multicolumn{5}{|c|}{ WOMEN AGENCY, OPPORTUNITIES AND GENDER BASED VIOLENCE } \\
\hline
\end{tabular}




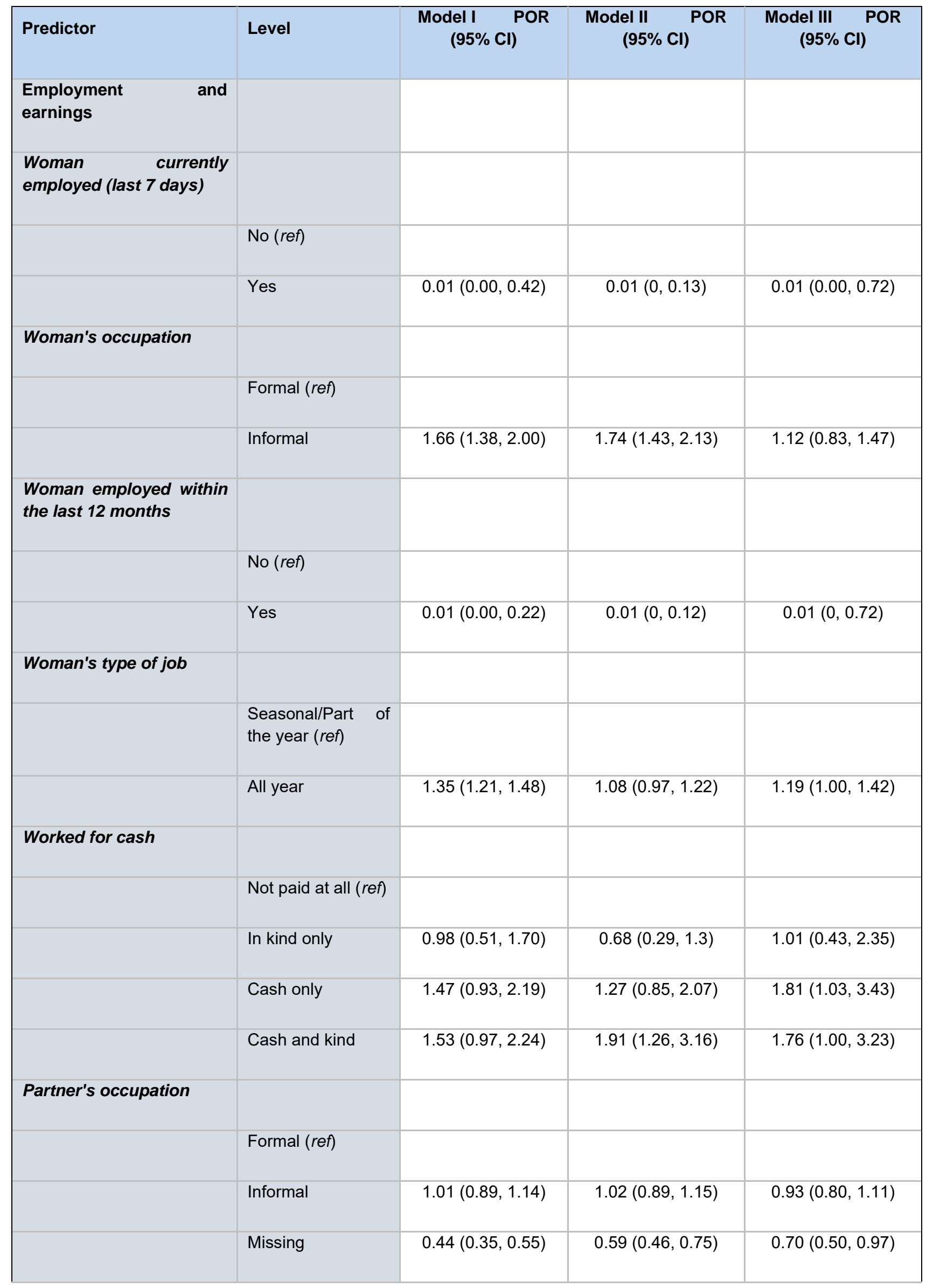




\begin{tabular}{|c|c|c|c|c|}
\hline Predictor & Level & $\begin{array}{c}\text { Model I POR } \\
(95 \% \mathrm{Cl})\end{array}$ & $\begin{array}{l}\text { Model II POR } \\
(95 \% \mathrm{Cl})\end{array}$ & $\begin{array}{l}\text { Model III POR } \\
(95 \% \mathrm{Cl})\end{array}$ \\
\hline \multicolumn{5}{|l|}{ Type of union } \\
\hline & Polygamous (ref) & & & \\
\hline & Monogamous & $0.85(0.78,0.94)$ & $0.91(0.83,1)$ & $1.02(0.91,1.16)$ \\
\hline & Missing & $0.58(0.37,0.89)$ & $0.61(0.33,1.09)$ & $1.06(0.5,1.94)$ \\
\hline \multicolumn{5}{|l|}{ Woman owns land } \\
\hline & Self (ref) & & & \\
\hline & Does not own & $1.07(0.91,1.26)$ & $1.13(0.96,1.35)$ & $1.14(0.91,1.45)$ \\
\hline & Owns jointly & $0.88(0.73,1.04)$ & $1.11(0.92,1.35)$ & $1.32(1.02,1.69)$ \\
\hline \multicolumn{5}{|l|}{ Woman owns house } \\
\hline & Self (ref) & & & \\
\hline & Does not own & $1.03(0.85,1.24)$ & $0.83(0.66,1.03)$ & $0.83(0.63,1.14)$ \\
\hline & Owns jointly & $1.37(1.11,1.70)$ & $0.94(0.74,1.19)$ & $0.87(0.65,1.21)$ \\
\hline \multicolumn{5}{|l|}{$\begin{array}{l}\text { Who usually decides on } \\
\text { woman's cash spending } \\
\text { (currently married women } \\
\text { only) }\end{array}$} \\
\hline & $\begin{array}{l}\text { Respondent alone } \\
\text { (ref) }\end{array}$ & & & \\
\hline & $\begin{array}{l}\text { Husband/partner } \\
\text { alone }\end{array}$ & $0.69(0.59,0.80)$ & $0.85(0.72,1.02)$ & $1.00(0.80,1.23)$ \\
\hline & $\begin{array}{l}\text { Respondent and } \\
\text { husband/partner }\end{array}$ & $0.82(0.74,0.91)$ & $0.92(0.81,1.05)$ & $0.97(0.81,1.14)$ \\
\hline & Missing & $0.70(0.46,1.07)$ & $1.07(0.72,1.75)$ & $1.61(0.87,3.08)$ \\
\hline \multicolumn{5}{|l|}{$\begin{array}{l}\text { Woman who have } \\
\text { experienced physical and } \\
\text { sexual violence }\end{array}$} \\
\hline & No (ref) & & & \\
\hline
\end{tabular}




\begin{tabular}{|c|c|c|c|c|}
\hline Predictor & Level & $\begin{array}{l}\text { Model I POR } \\
(95 \% \mathrm{Cl})\end{array}$ & $\begin{array}{l}\text { Model II POR } \\
(95 \% \mathrm{Cl})\end{array}$ & $\begin{array}{c}\text { Model III POR } \\
(95 \% \mathrm{Cl})\end{array}$ \\
\hline & Yes & $0.17(0.06,0.41)$ & $0.38(0.16,0.96)$ & $0.39(0.12,1.03)$ \\
\hline & Missing & $0.93(0.86,1.01)$ & $0.95(0.87,1.03)$ & $0.84(0.65,1.08)$ \\
\hline \multicolumn{5}{|c|}{ ACTUAL WOMEN MOBILITY, MIXED ETHNICITY \& MEDIA INFORMATION } \\
\hline \multicolumn{5}{|l|}{$\begin{array}{l}\text { Number of trips away } \\
\text { from the community } \\
\text { (slept away) in the last } 12 \\
\text { months }\end{array}$} \\
\hline & 0 (ref) & & & \\
\hline & $1-25$ trips & $0.91(0.86,0.97)$ & $0.95(0.89,1.03)$ & $0.97(0.87,1.08)$ \\
\hline & $26-50$ trips & $0.91(0.60,1.37)$ & $1.89(1.1,3.01)$ & $1.32(0.7,2.72)$ \\
\hline & 51 trips or more & $0.85(0.51,1.48)$ & $1.4(0.71,2.68)$ & $1.99(0.75,5.43)$ \\
\hline \multicolumn{5}{|l|}{$\begin{array}{l}\text { Respondent from mixed } \\
\text { ethnicity }\end{array}$} \\
\hline & Mixed (ref) & & & \\
\hline & Same & $1.78(1.53,2.11)$ & $1.37(1.11,1.74)$ & $1.23(0.84,1.85)$ \\
\hline & Missing & $1.67(1.44,1.99)$ & $1.36(1.12,1.68)$ & $1.24(0.82,1.84)$ \\
\hline \multicolumn{5}{|l|}{ Media Information } \\
\hline \multicolumn{5}{|l|}{$\begin{array}{l}\text { Woman reads } \\
\text { newspapers/ magazines }\end{array}$} \\
\hline & Not at all (ref) & & & \\
\hline & $\begin{array}{l}\text { Less than once a } \\
\text { week }\end{array}$ & $0.55(0.48,0.63)$ & $0.54(0.47,0.62)$ & $0.68(0.57,0.83)$ \\
\hline & $\begin{array}{l}\text { At least once a } \\
\text { week }\end{array}$ & $0.50(0.42,0.59)$ & $0.51(0.43,0.6)$ & $0.9(0.68,1.2)$ \\
\hline \multicolumn{5}{|l|}{ Woman listens to radio } \\
\hline & Not at all (ref) & & & \\
\hline
\end{tabular}




\begin{tabular}{|c|c|c|c|c|}
\hline \multirow[t]{3}{*}{ Predictor } & Level & $\begin{array}{l}\text { Model I POR } \\
(95 \% \mathrm{Cl})\end{array}$ & $\begin{array}{c}\text { Model II POR } \\
(95 \% \mathrm{Cl})\end{array}$ & $\begin{array}{c}\text { Model III POR } \\
(95 \% \mathrm{Cl})\end{array}$ \\
\hline & $\begin{array}{l}\text { Less than once a } \\
\text { week }\end{array}$ & $1.39(1.27,1.51)$ & $1.12(1.02,1.23)$ & $1.23(1.04,1.46)$ \\
\hline & $\begin{array}{l}\text { At least once a } \\
\text { week }\end{array}$ & $1.44(1.32,1.57)$ & $0.94(0.85,1.03)$ & $1.16(1,1.37)$ \\
\hline \multicolumn{5}{|c|}{ Woman watches TV } \\
\hline & \multicolumn{2}{|l|}{ Not at all (ref) } & & \\
\hline & $\begin{array}{l}\text { Less than once a } \\
\text { week }\end{array}$ & $0.94(0.85,1.02)$ & $0.97(0.87,1.07)$ & $0.9(0.77,1.06)$ \\
\hline & $\begin{array}{l}\text { At least once a } \\
\text { week }\end{array}$ & $0.61(0.56,0.66)$ & $0.72(0.65,0.8)$ & $0.77(0.64,0.94)$ \\
\hline
\end{tabular}

Model I: Unadjusted Model

Model II: Adjusted with Unobserved spatial location effects.

Model III: Fully adjusted spatial model with all significant potential confounders.

POR = Posterior Odds Ratio; $\mathrm{Cl}=$ Credible Interval. 
Table A6. Table A 6. Unadjusted and adjusted posterior odds ratios (POR) and associated $95 \%$ credible intervals $(\mathrm{Cl})$ from Bayesian Geo-additive hierarchical logistic regression models, using MICS 2016-17

\begin{tabular}{|c|c|c|c|c|}
\hline Predictor & Level & $\begin{array}{l}\text { Model I } \quad \text { POR } \\
(95 \% \mathrm{Cl})\end{array}$ & $\begin{array}{ll}\text { Model II } & \text { POR } \\
(95 \% \mathrm{Cl}) & \end{array}$ & $\begin{array}{l}\text { Model III } \quad \text { POR } \\
(95 \% \mathrm{Cl})\end{array}$ \\
\hline \multicolumn{5}{|c|}{ DEMOGRAPHIC } \\
\hline \multicolumn{5}{|c|}{ Place of residence } \\
\hline & Rural (ref) & & & \\
\hline & Urban & $0.71(0.66,0.77)$ & $0.65(0.59,0.72)$ & $0.96(0.81,1.16)$ \\
\hline \multicolumn{5}{|l|}{ Region } \\
\hline & North Central (ref) & & & \\
\hline & North East & $0.16(0.11,0.22)$ & $0.13(0.02,1.21)$ & $0.24(0.03,1.37)$ \\
\hline & North West & $7.82(6.86,8.8)$ & $5.81(2.43,15.55)$ & $6.04(2.11,22.83)$ \\
\hline & South East & $0.83(0.7,1)$ & $1.24(0.13,12.46)$ & $1.41(0.33,6.12)$ \\
\hline & South South & $0.43(0.36,0.5)$ & $1.08(0.23,7.12)$ & $1.23(0.28,5.41)$ \\
\hline & South West & $1.66(1.42,1.92)$ & $11.41(2.38,48.9)$ & $1.91(0.48,10.6)$ \\
\hline \multicolumn{5}{|c|}{ Wealth Index } \\
\hline & Middle (ref) & & & \\
\hline & Lowest & $2.55(2.26,2.85)$ & $1.37(1.15,1.62)$ & $1.2(0.9,1.55)$ \\
\hline & Second & $1.69(1.52,1.91)$ & $1.22(1.05,1.43)$ & $1.21(0.95,1.53)$ \\
\hline & Higher & $0.79(0.71,0.89)$ & $0.81(0.7,0.92)$ & $1.06(0.88,1.3)$ \\
\hline & Highest & $0.5(0.44,0.56)$ & $0.47(0.4,0.55)$ & $1.06(0.87,1.31)$ \\
\hline \multicolumn{5}{|c|}{ Marital status } \\
\hline & $\begin{array}{l}\text { Currently married/in } \\
\text { union (ref) }\end{array}$ & & & \\
\hline & Never married & $0.69(0.58,0.83)$ & $0.39(0.18,0.67)$ & $0.62(0.29,1.34)$ \\
\hline & Formerly married & $0.16(0.09,0.3)$ & $1.28(1.04,1.62)$ & $1.45(1.08,1.98)$ \\
\hline
\end{tabular}




\begin{tabular}{|c|c|c|c|c|}
\hline Predictor & Level & $\begin{array}{l}\text { Model I } \quad \text { POR } \\
(95 \% \mathrm{Cl})\end{array}$ & $\begin{array}{l}\text { Model II } \quad \text { POR } \\
(95 \% \mathrm{Cl})\end{array}$ & $\begin{array}{l}\text { Model III POR } \\
(95 \% \mathrm{Cl})\end{array}$ \\
\hline \multicolumn{5}{|l|}{$\begin{array}{l}\text { Age difference with } \\
\text { husband/partner } \\
\text { (currently married women } \\
\text { only) }\end{array}$} \\
\hline & Wife is older (ref) & & & \\
\hline & Wife is same age & $0.35(0.26,0.51)$ & $0.61(0.4,0.9)$ & $0.74(0.4,1.36)$ \\
\hline & $\begin{array}{l}\text { Wife is 1-4 years } \\
\text { younger }\end{array}$ & $0.27(0.21,0.32)$ & $0.44(0.34,0.58)$ & $0.59(0.39,0.9)$ \\
\hline & $\begin{array}{l}\text { Wife is 5-9 years } \\
\text { younger }\end{array}$ & $0.31(0.26,0.37)$ & $0.41(0.33,0.54)$ & $0.56(0.39,0.85)$ \\
\hline & $\begin{array}{l}\text { Wife is } 10+\text { years } \\
\text { younger }\end{array}$ & $0.47(0.4,0.56)$ & $0.51(0.41,0.65)$ & $0.62(0.43,0.95)$ \\
\hline \multicolumn{5}{|l|}{ Ethnicity } \\
\hline & Fulani (ref) & & & \\
\hline & Hausa & & & \\
\hline & Igbo & $0.16(0.15,0.19)$ & $0.49(0.35,0.66)$ & $0.8(0.49,1.27)$ \\
\hline & Kanuri & & & \\
\hline & Tiv & & & \\
\hline & Yoruba & $0.47(0.43,0.52)$ & $1.07(0.85,1.4)$ & $1.14(0.8,1.78)$ \\
\hline & Other & $0.09(0.08,0.1)$ & $0.29(0.23,0.35)$ & $0.4(0.27,0.59)$ \\
\hline \multicolumn{5}{|l|}{ SOCIAL NORMS \& BELIEFS } \\
\hline \multicolumn{5}{|l|}{$\begin{array}{l}\text { Women's } \\
\text { toward FGM/C }\end{array}$} \\
\hline \multicolumn{5}{|l|}{ Mother Cut } \\
\hline & No (ref) & & & \\
\hline & Yes & $9.14(8.10,10.16)$ & $14.62(12.46,17.12)$ & $11.51(9.66,14.06)$ \\
\hline Benefit of FGM/C & & & & \\
\hline
\end{tabular}




\begin{tabular}{|c|c|c|c|c|}
\hline Predictor & Level & $\begin{array}{l}\text { Model I } \quad \text { POR } \\
(95 \% \mathrm{Cl})\end{array}$ & $\begin{array}{l}\text { Model II } \quad \text { POR } \\
(95 \% \mathrm{Cl})\end{array}$ & $\begin{array}{l}\text { Model III POR } \\
(95 \% \mathrm{Cl})\end{array}$ \\
\hline \multicolumn{5}{|l|}{$\begin{array}{l}\text { Circumcision should } \\
\text { continue or be stopped. }\end{array}$} \\
\hline & Discontinued (ref) & & & \\
\hline & Continued & $\begin{array}{r}17.88 \quad(15.93, \\
20.09)\end{array}$ & $14.94(13,17.15)$ & $\begin{array}{c}14.31(12.45 \\
16.34)\end{array}$ \\
\hline & Depends/Don't know & $4.65(3.93,5.43)$ & $3.61(2.97,4.36)$ & $3.17(2.5,3.93)$ \\
\hline \multicolumn{5}{|c|}{ WOMEN'S AGENCY/ OPPORTUNITIES } \\
\hline \multirow[t]{4}{*}{ Woman's education } & Higher (ref) & & & \\
\hline & No education & $11.1(9.31,13.13)$ & $6.4(5.14,8.09)$ & $1.68(1.19,2.35)$ \\
\hline & Primary & $2.36(2.02,2.76)$ & $3.15(2.61,3.84)$ & $1.36(1.06,1.74)$ \\
\hline & Secondary & $1.81(1.53,2.16)$ & $2.28(1.89,2.79)$ & $1.37(1.1,1.77)$ \\
\hline \multicolumn{5}{|c|}{ GENDER NORMS \& BASED VIOLENCE } \\
\hline \multirow{11}{*}{$\begin{array}{l}\text { Husband is justified in } \\
\text { hitting or beating his wife } \\
\text { if she: }\end{array}$} & No (ref) & & & \\
\hline & $\begin{array}{l}\text { Goes out without telling } \\
\text { him }\end{array}$ & $1.04(0.91,1.20)$ & $1.35(1.15,1.59)$ & $1.31(1.01,1.72)$ \\
\hline & Missing & $0.18(0.05,0.60)$ & $0.26(0.07,0.9)$ & $0.41(0.04,2.75)$ \\
\hline & Neglects children & $0.73(0.65,0.83)$ & $0.83(0.71,0.96)$ & $0.58(0.46,0.71)$ \\
\hline & Missing & $0.62(0.28,1.16)$ & $0.47(0.2,1.14)$ & $1.15(0.32,3.82)$ \\
\hline & Argues & $0.95(0.83,1.09)$ & $1.05(0.9,1.25)$ & $1.18(0.92,1.51)$ \\
\hline & Missing & $0.57(0.26,1.04)$ & $0.44(0.17,1.02)$ & $0.75(0.23,2.29)$ \\
\hline & Denies Sex & $1.20(1.08,1.33)$ & $1.25(1.07,1.48)$ & $1.29(1.03,1.6)$ \\
\hline & Missing & $1.07(0.63,1.70)$ & $1.55(0.86,2.63)$ & $1.66(0.7,3.7)$ \\
\hline & Burns food & $1.24(1.07,1.44)$ & $0.93(0.78,1.11)$ & $0.86(0.65,1.12)$ \\
\hline & Missing & $2.00(1.36,2.84)$ & $1.89(1.2,3.12)$ & $2.97(1.39,6.25)$ \\
\hline
\end{tabular}


Model I: Unadjusted Model

Model II: Adjusted with Unobserved spatial location effects.

Model III: Fully adjusted spatial model with all significant potential confounders.

POR = Posterior Odds Ratio; $\mathrm{Cl}=$ Credible Interval. 
Table A7. Unadjusted and adjusted posterior odds ratios (POR) and associated 95\% credible intervals (Cl) from Bayesian Geo-additive hierarchical logistic Models using the pooled 2003 to 2016-17 data

\begin{tabular}{|c|c|c|c|}
\hline Predictor & Level & $\begin{array}{c}\text { Model I POR } \\
(95 \% \mathrm{Cl})\end{array}$ & $\begin{array}{c}\text { Model III } \\
\mathrm{Cl})\end{array}$ \\
\hline \multicolumn{4}{|c|}{ DEMOGRAPHIC } \\
\hline \multicolumn{4}{|c|}{ Place of residence } \\
\hline & Rural (ref) & & \\
\hline & Urban & $0.86(0.81,0.91)$ & $0.92(0.86,0.98)$ \\
\hline \multicolumn{4}{|l|}{ Region } \\
\hline & North Central (ref) & & \\
\hline & North East & $1.01(0.88,1.17)$ & $0.73(0.26,2.32)$ \\
\hline & North West & $4.33(3.87,4.82)$ & $1.79(0.33,5.75)$ \\
\hline & South East & $0.73(0.66,0.8)$ & $1.38(0.53,4.01)$ \\
\hline & South South & $0.4(0.36,0.45)$ & $0.48(0.15,1.58)$ \\
\hline & South West & $1.39(1.26,1.52)$ & $1.8(0.46,9.21)$ \\
\hline \multicolumn{4}{|c|}{ Wealth Index } \\
\hline & Middle (ref) & & \\
\hline & Lowest & $1.01(0.91,1.12)$ & $1.07(0.96,1.19)$ \\
\hline & Second & $1.09(1,1.21)$ & $1.15(1.05,1.26)$ \\
\hline & Higher & $0.96(0.88,1.03)$ & $0.89(0.82,0.96)$ \\
\hline & Highest & $0.84(0.77,0.92)$ & $0.84(0.76,0.92)$ \\
\hline \multicolumn{4}{|c|}{ Marital status } \\
\hline & $\begin{array}{l}\text { Currently married/in } \\
\text { union (ref) }\end{array}$ & & \\
\hline & Never married & $0.62(0.45,0.83)$ & $0.71(0.53,0.97)$ \\
\hline
\end{tabular}




\begin{tabular}{|c|c|c|c|}
\hline & Formerly married & $0.93(0.83,1.03)$ & $0.97(0.86,1.09)$ \\
\hline \multicolumn{4}{|l|}{$\begin{array}{l}\text { Age difference with } \\
\text { husband/partner } \\
\text { (currently married women } \\
\text { only) }\end{array}$} \\
\hline & Wife is older (ref) & & \\
\hline & Wife is same age & $0.65(0.47,0.9)$ & $0.57(0.39,0.85)$ \\
\hline & $\begin{array}{l}\text { Wife is } 1-4 \text { years } \\
\text { younger }\end{array}$ & $0.69(0.55,0.88)$ & $0.58(0.46,0.76)$ \\
\hline & $\begin{array}{l}\text { Wife is } 5-9 \text { years } \\
\text { younger }\end{array}$ & $0.7(0.56,0.88)$ & $0.59(0.47,0.76)$ \\
\hline & $\begin{array}{l}\text { Wife is } 10+\text { years } \\
\text { younger }\end{array}$ & $0.72(0.57,0.9)$ & $0.6(0.47,0.78)$ \\
\hline \multicolumn{4}{|c|}{ SOCIAL NORMS \& BELIEFS } \\
\hline \multicolumn{4}{|l|}{$\begin{array}{l}\text { Women's attitudes toward } \\
\text { FGM/C }\end{array}$} \\
\hline \multicolumn{4}{|l|}{ Mother Cut } \\
\hline & No (ref) & & \\
\hline & Yes & $31.32(28.98,33.61)$ & $21.13(19.55,22.88)$ \\
\hline \multicolumn{4}{|c|}{ WOMEN'S AGENCY/ OPPORTUNITIES } \\
\hline \multicolumn{4}{|l|}{ Woman's education } \\
\hline & Higher (ref) & & \\
\hline & No education & $2.14(1.89,2.46)$ & $2.54(2.22,2.89)$ \\
\hline & Primary & $1.62(1.43,1.82)$ & $1.99(1.77,2.25)$ \\
\hline & Secondary & $1.42(1.26,1.62)$ & $1.6(1.43,1.81)$ \\
\hline \multicolumn{4}{|c|}{$\begin{array}{l}\text { Model I: Unadjusted Model } \\
\text { Model II: Adjusted with Unobserved spatial location effects; Cl= Credible Interval. }\end{array}$} \\
\hline
\end{tabular}

